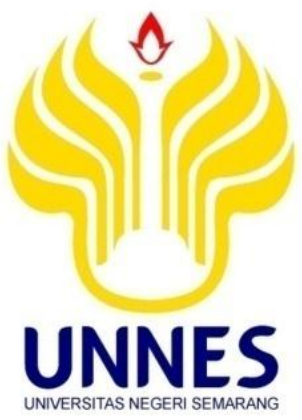

\title{
KARAWITAN PENDUKUNG KESENIAN BARONGAN RISANG GUNTUR SETO DI KABUPATEN BLORA
}

\section{SKRIPSI}

untuk memperoleh gelar Sarjana Pendidikan Seni Musik

oleh
Nama
: Reni Wulansari
NIM
: 2501411050
Program Studi : Pendidikan Seni Musik
Jurusan $\quad$ : Pendidikan Seni Drama Tari dan Musik

FAKULTAS BAHASA DAN SENI UNIVERSITAS NEGERI SEMARANG 2016 


\section{PERNYATAAN KEASLIAN SKRIPSI}

Saya menyatakan bahwa yang tertulis di dalam skripsi ini benar-benar hasil karya saya sendiri, bukan jiplakan dari karya orang lain, baik sebagian atau seluruhnya. Pendapat atau temuan orang lain yang terdapat dalam skripsi ini dikutip atau dirujuk berdasarkan kode etik ilmiah.

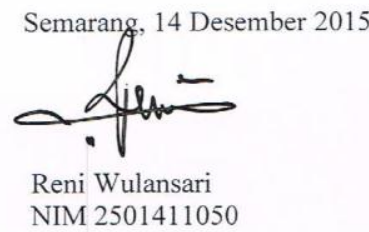




\section{MOTTO DAN PERSEMBAHAN}

Motto :

1. Allah tidak akan membebani seseorang melainkan sesuai dengan kesanggupannya (QS. Al - Baqarah : 286)

2. Karena mengulang doa-doa itu seperti kayuhan sepeda, suatu saat ia akan membawamu ke arah yang kamu tuju. Semoga dan selalu. Aamiin (Anonym)

\section{Persembahan :}

Dengan rasa syukur kepada Allah SWT atas semua nikmatNya kupersembahkan skripsi ini kepada :

1. Ayah dan Ibunda tercinta "Sumaryanto" dan "Manis Sabdha Rilawati" yang selalu mendukung dan mendoakan saya

2. Kakakku tercinta "Wisnu Setiaji"

3. Almamaterku "Universitas Negeri Semarang"

4. Sahabatku "Partiturcoustic"

5. Teman-teman Sendratasik angkatan 2011 


\section{KATA PENGANTAR}

Puji syukur atas kehadirat Allah SWT yang telah melimpahkan rahmat serta hidayahNya sehingga penulis dapat menyelesaikan skripsi dengan judul "Musik Pendukung Grup Kesenian Barongan Risang Guntur Seto di Kelurahan Kunden Kecamatan Blora Kabupaten Blora”.

Penyusunan skripsi ini tentu tidak terlepas dari dukungan, dorongan, dan bimbingan dari berbagai pihak. Untuk itu penulis ingin menyampaikan terima kasih kepada:

1. Prof. Dr. Fathur Rokhman, M.Hum., Rektor UNNES yang telah memberikan kesempatan pada penulis untuk menempuh studi di Universitas Negeri Semarang.

2. Prof. Dr. Agus Nuryatin, M.Hum., Dekan Fakultas Bahasa dan Seni Universitas Negeri Semarang yang telah memberikan izin penelitian kepada penulis.

3. Dr. Udi Utomo, M.Si., Ketua Jurusan Seni Drama, Tari dan Musik yang telah memberikan kesempatan dan arahan dalam penyusunan skripsi ini.

4. Joko Wiyoso, S.Kar., M.Hum., pembimbing satu yang telah sabar membimbing penulis dan memberikan kemudahan dalam penyusunan skripsi.

5. Kusrina Widjajantie, S.Pd., M.A., pembimbing dua yang juga telah membimbing penulis dengan penuh kesabaran dalam penyusunan skripsi. 
6. Seluruh Dosen Jurusan Pendidikan Seni Drama, Tari dan Musik yang telah memberikan bekal ilmu dan pengetahuan sehingga penulis mampu menyelesaikan skripsi.

7. Grup Kesenian Barongan Risang Guntur Seto yang telah memberikan keterangan, penjelasan, data penelitian.

8. Teman-teman dan mahasiswa Program Studi Pendidikan Seni Musik angkatan 2011, terimakasih telah memberikan semangat dan motivasi.

9. Seluruh keluarga yang senantiasa memberikan dukungan moril dan doa demi kelancaran studi hingga selesai.

10. Semua pihak yang telah membantu selama proses penelitian dan penulisan sampai selesainya skripsi.

Penulis menyadari bahwa masih banyak kekurangan dan kesalahan dalam penulisan skripsi ini. Oleh karena itu, saran dan kritik sangan diharapkan untuk penulisan berikutnya. Semoga skripsi ini dapat bermanfaat bagi pembaca dan semua pihak.

Penulis

Reni Wulansari 


\section{SARI}

Wulansari, Reni. 2015. Karawitan Pendukung Kesenian Barongan Risang Guntur Seto di Kabupaten Blora. Skripsi. Jurusan Pendidikan Seni Drama, Tari, dan Musik. Fakultas Bahasa dan Seni. Universitas Negeri Semarang. Pembimbing I: Joko Wiyoso, S.Kar., M.Hum., Pembimbing II: Kusrina Widjajantie, S.Pd., M.A.

Kata kunci: Karawitan, Kesenian Barongan Blora, Risang Guntur Seto.

Musik pendukung dalam seni pertunjukan sangat diperlukan, baik itu gamelan ataupun musik tradisional lainnya, dan musik modern. Karena hal itu akan menambah kekuatan dan menciptakan suasana yang dimaksud dalam pementasan tersebut. Demikian pula dalam kesenian barongan, karawitan pengiring juga mampu membantu dan menambah daya ungkap dan kekuatan tersendiri. Akan tetapi musik iringan yang dimainkan oleh grup kesenian barongan berbeda-beda antara yang satu dengan yang lain. Seperti grup Risang Guntur Seto, grup ini memiliki ciri khas dari temponya yang cepat dan terkesan energik, sehingga grup ini menjadi trendsetter bagi grup kesenian barongan di blora lainnya terutama dari segi pola iringan musiknya. Untuk mengetahui musik iringan/ karawitan pendukung barongan grup ini, rumusan masalah yang dapat dikaji dari penelitian ini adalah bagaimanakah karawitan pendukung kesenian barongan Risang Guntur Seto di Kabupaten Blora?

Pendekatan yang digunakan dalam penelitian ini adalah pendekatan karawitanologi, menggunakan metode penelitian dekriptif kualitatif dengan objek penelitian adalah grup kesenian barongan Blora Risang Guntur Seto, dan desain penelitian studi kasus. Lokasi penelitian berada di Jalan Gunung Wilis Nomor 12A Kelurahan Kunden Kecamatan Blora Kabupaten Blora. Sasaran kajian dalam penelitian ini adalah karawitan pendukung kesenian barongan Risang Guntur Seto. Data dikumpulkan melalui teknik observasi, wawancara dan dokumentasi. Analisis data dilakukan dengan cara reduksi data, penyajian data dan penarikan kesimpulan.

Inti dari musik iringan kesenian barongan Risang Guntur Seto adalah musik barongan bonang mo-nem laras slendro yang dimainkan dalam tempo yang cepat dan terus menerus kecuali pada saat iringan tembang dan lagu-lagu. Ketika musik ini dimainkan, penggerong dan sinden bersahutan memberikan alok. Lagu-lagu yang dibawakan menceritakan tentang sejarah barongan, liriknya berisi tentang keperkasaan dari barongan itu sendiri, dan musiknya mencerminkan ciri khas Kabupaten Blora. Sebagian besar gendhing nya berbentuk lancaran. Namun ada pula tembang macapat dan lagu populer anak-anak sebagai selingan.

Berdasarkan hasil penelitian di atas, saran bagi grup kesenian barongan Blora Risang Guntur Seto agar lebih mengkreasikan musik iringan seperti menambah jenis bentuk gendhing yang lain sehingga koleksi lagu pun bertambah. Serta mempertahankan kekompakan antar pemain. 


\section{DAFTAR ISI}

HALAMAN JUDUL ........................................................................ i

LEMBAR PENGESAHAN ................................................................... ii

HALAMAN PERNYATAAN .................................................................. iii

MOTTO DAN PERSEMBAHAN ........................................................... iv

KATA PENGANTAR .....................................................................

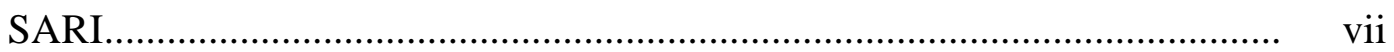

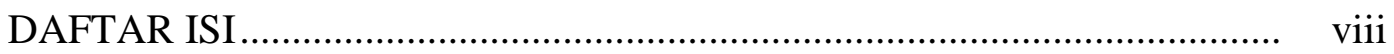

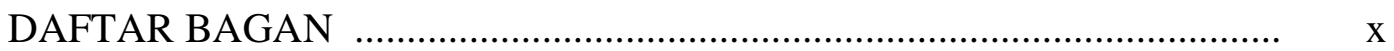

DAFTAR GAMBAR …...................................................................... xi

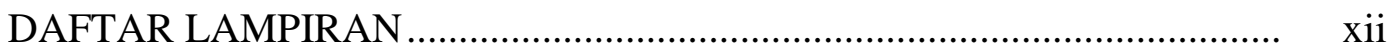

BAB 1 PENDAHULUAN _................................................................ 1

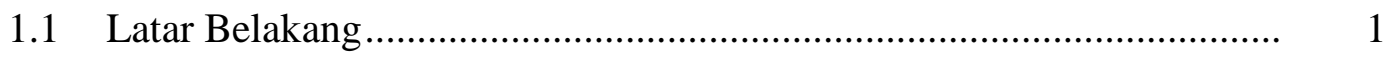

1.2 Rumusan Masalah......................................................................... 4

1.3 Tujuan Penelitian .............................................................................. 4

1.4 Manfaat Penelitian ............................................................................. 4

1.5 Sistematika Skripsi ....................................................................... 5

BAB 2 LANDASAN TEORI............................................................. 7

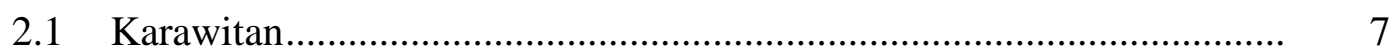

2.2 Seni dan Kesenian......................................................................... 14

2.3 Kesenian Tradisional ...................................................................... 14

2.4 Kesenian Barongan Blora ........................................................... 16

2.5 Tinjauan Pustaka............................................................................. 27

2.6 Kerangka Berfikir ...................................................................... 28

BAB 3 METODE PENELITIAN ................................................................ 30

3.1 Pendekatan Penelitian ........................................................................ $\quad 30$

3.2 Sasaran dan Lokasi Penelitian ................................................................ 32 
3.2.1 Lokasi Penelitian ...................................................................... 32

3.2.2 Sasaran Penelitian ........................................................................... 32

3.3 Data dan Sumber Data ......................................................................... 32

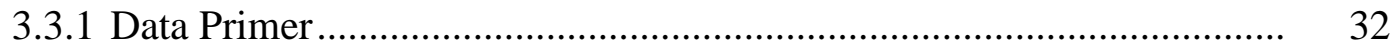

3.3.2 Data Sekunder............................................................................... 33

3.4 Teknik Pengumpulan Data ................................................................ 33

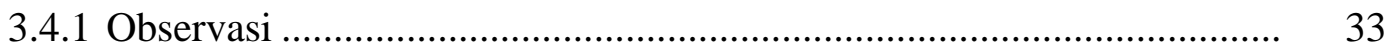

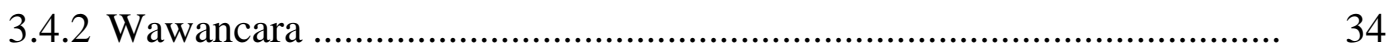

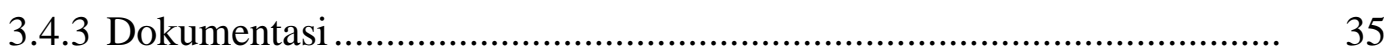

3.5 Teknik Analisis Data ..................................................................... 35

3.6 Teknik Pemeriksaan Keabsahan Data ................................................ 37

BAB 4 HASIL PENELITIAN DAN PEMBAHASAN ................................. 39

4.1 Gambaran Umum Lokasi Penelitian...................................................... 39

4.2 Sejarah Grup Kesenian Barongan Blora Risang Guntur Seto ............... 42

4.3 Susunan Pengurus Grup Kesenian Barongan Blora Risang Guntur Seto 44

4.4 Penyajian Kesenian Barongan Grup Risang Guntur Seto .................... 44

4.4.1 Persiapan Pemain........................................................................... 46

4.4.2 Urutan Penyajian Musik Pendukung Grup Kesenian Barongan Risang

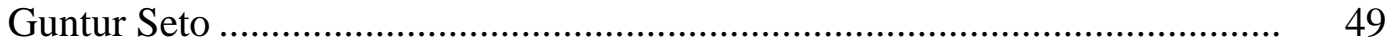

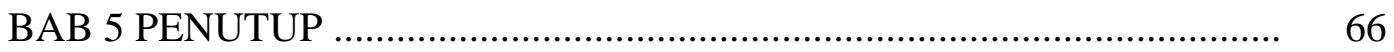

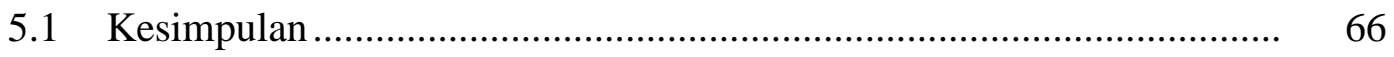

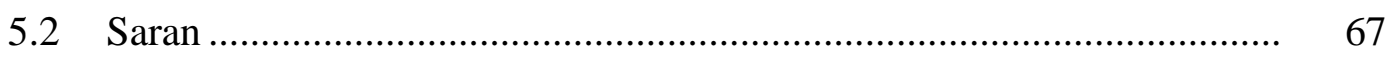

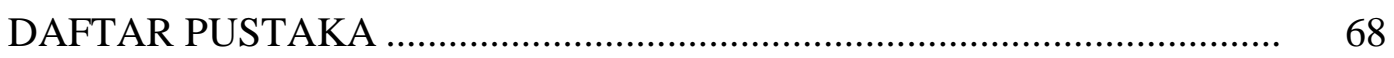

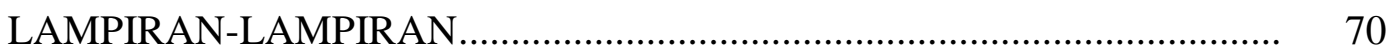




\section{DAFTAR BAGAN}

Tabel 2.1 Kerangka Berfikir.................................................................. 28

Tabel 3.1 Analisis Data Kualitatif .............................................................. 37 


\section{DAFTAR GAMBAR}

Gambar 2.1 Tempat Pentas Bentuk Arena ............................................... 26

Gambar 4.1 Peta Kabupaten Blora ........................................................ 40

Gambar 4.2 Peta Lokasi Grup Kesenian Barongan Risang Guntur Seto ..... 41

Gambar 4.3 Bagian Luar Lokasi Grup Risang Guntur Seto....................... 42

Gambar 4.4 Foto Peneliti dengan Ketua Grup Risang Guntur Seto............ 43

Gambar 4.5 Alat Musik Pendukung Barongan Risang Guntur Seto........... 45

Gambar 4.6 Alat Musik Pendukung Barongan Risang Guntur Seto........... 45

Gambar 4.7 Kostum Pengrawit Grup Risang Guntur Seto ....................... 47

Gambar 4.8 Kostum Penari Jaranan Grup Risang Guntur Seto .................. 48

Gambar 4.9 Penari masuk ke area panggung .......................................... 50

Gambar 4.10 Pawang dan Barongannya ....................................................... 54

Gambar 4.11 Pawang Ngudang Barongan ............................................. 58

Gambar 4.12 Barongan Mulai Berdiri dan Menari ..................................... 59

Gambar 4.13 Penthul Bujangganong ..................................................... 60

Gambar 4.14 Penari Jaranan ................................................................. 61

Gambar 4.15 Nggainah, Untub, dan Nayantaka ......................................... 62 


\section{DAFTAR LAMPIRAN}

Lampiran 1 Pedoman Observasi .............................................................. $\quad 70$

Lampiran 2 Pedoman Wawancara ........................................................ 71

Lampiran 3 Pedoman Dokumentasi .............................................................. 74

Lampiran 4 Transkrip Wawancara Ketua Grup Risang Guntur Seto ........... 75

Lampiran 5 Transkrip Wawancara Pengrawit Grup Risang Guntur Seto ...... 79

Lampiran 6 Transkrip Wawancara Penanggap Risang Guntur Seto ............. 84

Lampiran 7 Rangkaian Foto Kegiatan .................................................... 87

Lampiran 8 Surat Penetapan Dosen Pembimbing .................................... $\quad 90$

Lampiran 9 Surat Permohonan Izin Penelitian ............................................. 91

Lampiran 10 Surat Keterangan Penelitian ................................................... 92 


\section{BAB 1 \\ PENDAHULUAN}

\subsection{Latar Belakang}

Kata "kebudayaan" berasal dari kata Sanskerta buddayah, yaitu bentuk jamak dari buddhi yang berarti "budi" atau "akal". Dengan demikian ke-budayaan dapat diartikan: "hal-hal yang bersangkutan dengan akal". Ada sarjana lain yang membedakan "budaya" dan "kebudayaan". Demikianlah "budaya" adalah “daya dan buddhi" yang berupa cipta, karsa, dan rasa. Sedangkan "kebudayaan” adalah hasil dari cipta, karsa, dan rasa itu. Dalam istilah "antropologi-budaya" perbedaan itu ditiadakan. Kata "budaya" disini hanya dipakai sebagai suatu singkatan saja dari "kebudayaan" dengan arti yang sama.

Djojodigono (1958) memberikan definisi mengenai kebudayaan dengan mengatakan kebudayaan itu adalah daya dari budi, yang berupa cipta, karsa dan rasa. Rasa seni yang dimiliki oleh setiap manusia secara naluriah menyebabkan setiap individu mempunyai bakat untuk menciptkan seni, karena berkesenian merupakan kebutuhan setiap manusia.

Kesenian mengacu pada nilai keindahan (estetika) yang berasal dari ekspresi hasrat manusia akan keindahan yang dinikmati dengan mata ataupun telinga. Sebagai makhluk yang mempunyai cita rasa tinggi, manusia menghasilkan berbagai corak kesenian mulai dari yang sederhana hingga perwujudan kesenian yang kompleks. Unsur kesenian yang menjadi bagian hidup masyarakat dalam suatu kaum/puak/suku/bangsa tertentu disebut sebagai seni tradisional. 
Indonesia merupakan salah satu negara di Asia Tenggara yang terletak diantara benua Asia dan Australia. Dari sabang sampai Merauke, Indonesia terdiri dari berbagai suku bangsa, bahasa, dan agama. Setiap suku memiliki tradisi masing-masing yang digunakan sebagai ciri khas dari daerah itu sendiri. Tradisi yang diturunkan oleh nenek moyang dari generasi ke generasi tersebut digunakan sebagai cara untuk bertahan hidup dalam sebuah kelompok, yang kemudian berkembang dan disebut sebagai budaya atau kebudayaan.

Kabupaten Blora merupakan salah satu wilayah di Jawa Tengah yang memiliki kesenian tradisional yang cukup beragam, salah satunya adalah kesenian barongan. Kesenian barongan merupakan kesenian yang disajikan dalam bentuk tarian, menggunakan topeng besar berbentuk harimau raksasa yang disebut Singabarong. Tari barongan ini diambil dari cerita Panji. Panji adalah seorang Putra Kerajaan Singosari yang menyamar sebagai pengamen. Dia mengamen dengan melakukan tari barongan. Penyamaran yang dia lakukan adalah untuk mengembara mencari kekasihnya yaitu Ayu Galuh Candra Kirana. Demikian sedikit ringkasan tentang Barongan Blora yang sampai sekarang menjadi ikon dari Kabupaten Blora.

Pada jaman dahulu, kesenian barongan dilibatkan dalam syarat budaya tradisi. Tradisi lamporan (ritual tolak bala) misalnya, mengharuskan keterlibatan barongan. Bahkan, justru Singo Barong yang dianggap sebagai pengusir tolak bala. Tak mengherankan bila kesenian barongan sangat populer dan sangat lekat dengan kehidupan masyarakat pedesaan di Kabupaten Blora. Mereka beranggapan bahwa barongan telah berhasil mewakili sifat-sifat kerakyatan mereka, seperti 
spontanitas, kekeluargaan, kesederhanaan, tegas, kekompakan, dan keberanian yang didasarkan pada kebenaran.

Kabupaten Blora masih sangat mempertahankan Kesenian Barongan secara turun temurun dari leluhurnya. Tidak heran bahwa di Kabupaten Blora terdapat lebih dari 600 paguyuban kesenian barongan. Musik iringan yang digunakan dalam kesenian ini memiliki corak musik pentatonis yang khas dari kebudayaan masyarakat setempat yang diyakini memiliki kekuatan magis.

Musik pendukung dalam seni pertunjukan sangat diperlukan, baik itu gamelan, ataupun musik tradisional lainnya, dan musik modern. Karena hal itu akan menambah kekuatan dan menciptakan suasana yang dimaksud dalam pementasan tersebut. Instrumen iringan tari adalah jenis tabuhan dalam karawitan dan aransemen yang dihasilkan mampu membantu kekuatan ungkap karya tari sebagai bentuk ekspresi seni (Tasman 1997:2). Demikian pula dalam Kesenian Barongan, iringan musik juga mampu membantu dan menambah daya ungkap dan kekuatan tersendiri.

Sudarsono (dalam Harsana 2007:5) mengatakan bahwa musik atau iringan tari bukan hanya sekedar iringan, tetapi musik dalam tari adalah partner yang tidak boleh ditinggalkan. Karena musik adalah partner tari, maka musik yang yang digunakan untuk mengiringi tari harus digarap secara serius dan sesuai dengan garapan tarinya.

Peran musik pada kesenian barongan sangat penting. Akan tetapi musik iringan yang dimainkan oleh grup kesenian barongan berbeda-beda antara yang satu dengan yang lain. Masing-masing grup memiliki ciri khas pola iringan 
tersendiri. Grup kesenian barongan Risang Guntur Seto misalnya. Grup ini memiliki ciri khas dari temponya yang cepat dan terkesan energik. Grup ini menjadi trendsetter bagi grup kesenian barongan yang lain, dari segi pola iringan musiknya maupun gerak tariannya. Oleh karena itu peneliti terinspirasi untuk melakukan penelitian tentang "Karawitan Pendukung Kesenian Barongan Risang Guntur Seto di Kabupaten Blora”.

\subsection{Rumusan Masalah}

Berdasarkan latar belakang tersebut, permasalahan yang menjadi bagian kajian dalam penelitian ini adalah: Bagaimanakah karawitan pendukung kesenian barongan Risang Guntur Seto di Kabupaten Blora?

\subsection{Tujuan Penelitian}

Tujuan yang diharapkan dari penelitian ini adalah untuk mengetahui karawitan pendukung kesenian barongan Risang Guntur Seto di Kabupaten Blora.

\subsection{Manfaat Penelitian}

Berdasar dari tujuan penelitian yang telah diuraikan mengenai karawitan pendukung grup kesenian barongan Risang Guntur Seto, dapat disampaikan mengenai manfaat dari hasil penelitian ini. Manfaat yang disampaikan ada dua yakni manfaat teoritis dan praktis. 
Manfaat praktis bagi peneliti, penelitian ini dapat menambah wawasan dan pengetahuan mengenai karawitan pendukung Kesenian Barongan khususnya grup kesenian barongan Risang Guntur Seto. Sedangkan bagi pembaca, penelitian ini dapat memberikan informasi secara tertulis maupun sebagai referensi mengenai karawitan pendukung Kesenian Barongan khususnya grup kesenian barongan Risang Guntur Seto.

Manfaat teoritis setelah adanya penelitian ini adalah dapat dijadikan acuan atau wacana bagi masyarakat untuk mengetahui karawitan pendukung Kesenian Barongan dan perkembangannya, sebagai bahan bacaan untuk pembaca, dan dapat digunakan sebagai dasar untuk kegiatan penelitian selanjutnya.

\subsection{Sistematika Skripsi}

Sistematika skripsi memudahkan memahami jalan pikiran secara keseluruhan, penelitian skripsi terbagi menjadi 3 bagian yaitu; 1) Bagian awal, 2) Isi, dan 3) Bagian akhir. Bagian awal skripsi yang berisi judul skripsi, halaman pengesahan, halaman pernyataan, halaman motto dan persembahan, kata pengantar, sari, daftar isi, daftar bagan, daftar gambar, dan daftar lampiran. Bagian isi terdiri atas; 1) BAB I Pendahuluan, 2) BAB II Landasan Teori, 3) BAB III Metode Penelitian, 4) BAB IV Hasil Penelitian dan Pembahasan, 5) BAB V Penutup. Bagian akhir skripsi merupakan daftar pustaka dan lampiran-lampiran terkait dengan penelitian skripsi.

Bab I merupakan Pendahuluan yang memuat; (a) Latar Belakang Masalah,

(b) Rumusan Masalah, (c) Tujuan Penelitian, (d) Manfaat Penelitian, 
(e) Sistematika Skripsi. BAB II yakni Landasan Teori, dalam bab ini diuraikan teori-teori tentang pengertian karawitan, pengertian seni dan kesenian, dan pengertian kesenian tradisional Barongan yang dikemukakan oleh para ahli. BAB III merupakan Metode Penelitian, berisi tentang cara-cara yang dilakukan peneliti dalam melakukan peneltian yaitu : Pendekatan Penelitian, Lokasi dan Sasaran Penelitian, Data dan Sumber Data, Teknik Pengumpulan Data, Teknik Analisis Data, dan Teknik Pemeriksaan Keabsahan Data. BAB IV adalah Hasil Penelitian dan Pembahasan, yakni menguraikan deskripsi gambaran umum, hasil penelitian, dan pembahasan secara deskriptif kualitatif terkait penelitian skripsi. BAB V ialah Penutup yang berisikan Kesimpulan dan Saran terhadap hasil penelitian dan pembahasan. Bagian akhir pada sistematika skripsi berisikan daftar pustaka dan lampiran-lampiran. 


\section{BAB 2}

\section{LANDASAN TEORI}

\subsection{Karawitan}

Karawitan/ musik gamelan/ musik gong adalah salah satu jenis seni bebunyian yang dianggap tua dan masih bertahan hidup dan berkembang sampai sekarang di Jawa. Banyak orang memaknai karawitan dari kata dasarnya rawit yang berarti kecil, halus atau rumit. Oleh karena itu kemudian karawitan digunakan untuk menyebut atau mewadahi beberapa cabang seni yang memiliki karakter yang halus, kecil, rumit, atau sejenisnya (Bothekan Karawitan I).

Sedangkan pengertian karawitan yang lebih sempit, khusus dan konsvensional adalah menyebut suatu jenis seni suara atau musik yang mengandung salah satu atau kedua unsur sebagai berikut: (1) Menggunakan alat musik gamelan - sebagian atau seluruhnya - baik berlaras slendro atau pelog atau laras lain - sebagian atau semuanya. (2) Menggunakan laras (tangga nada) slendro dan/ atau pelog, baik instrumental - gamelan atau non gamelan - maupun vokal atau campuran dari keduanya.

Gamelan merupakan seperangkat ricikan/ alat musik/ instrumen yang sebagian besar terdiri dari alat musik pukul atau perkusi, yang dibuat dari bahan utama logam (perunggu, kuningan, besi atau bahan yang lain), dilengkapi dengan ricikan-ricikan dengan bahan kayu dan/ atau kulit maupun campuran dari dua atau ketiga bagan tersebut.

Ricikan gamelan dibedakan menjadi : (1) Kelompok wilahan atau bilah yang terdiri dari rangkaian wilah (bilahan) logam atau kayu (untuk ricikan 
gambang), mulai dari yang berjumlah dua (gong kemodhang), enam (contoh: ricikan balungan), sampai dua puluh satu bilah (contoh: ricikan gambang), dengan berbagai bentuk dan ukuran, disusun urut mulai dari bilah yang berlaras (bernada) paling rendah pada sisi kiri pengrawit (pemusik), urut ke kanan menuju bilah-bilah yang dilaras lebih tinggi. Ricikan-ricikan gamelan yang menggunakan bilah antara lain: slenthem, gender barung, gender penerus, saron barung, saron penerus, gambang, dan gambang gangsa. (2) Kelompok ricikan pencon yang juga sering juga disebut ricikan bunderan, karena lakaran ricikan ini berawal dari bentuk bulat pipih, semacam cakram atau serabi dari cor perunggu yang kemudian ditempa (lewat pembakaran) dan dibentuk melebar dan melengkung sampai mencapai bentuk akhir. Ricikan yang termasuk dalam golongan ini adalah beberapa jenis gong (ageng, siyem, suwukan), kempul, bendhe, penonthong, kenong, kethuk, kempyang, engkuk, kemong (bonang) penembung, bonang barung, bonang penerus, kenut, klenang, bangge(n), penitir (kenong) japan, kecer, dan sebagainya dengan cara digantung.

Dalam dunia karawitan digunakan dua laras utama, yaitu: (1) Slendro. Sistem urutan nadanya terdiri dari lima nada dalam satu gembyang dengan pola jarak yang hampir sama rata. Susunan dan pola interval itu diatur sebagai berikut :

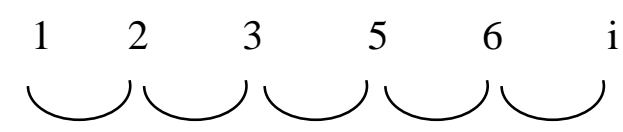

Sedangkan laras yang digunakan dalam laras slendro adalah Penunggul, atau sering juga disebut dengan barang, diberi simbol 1 (angka arab satu), dan dibaca siji atau ji; Gulu, atau jangga (krama jw), diberi simbol 2 (angka arab dua) 
dibaca loro atau disingkat ro; Dhadha, atau jaja atau tengah, diberi simbol 3 (angka arab tiga), dan dibaca telu atau dibaca singkat $l u$; Lima, diberi simbol 5 (angka arab lima), dibaca lima, atau ma sebagai bacaan singkatnya; Nem, diberi simbol 6 (angka arab enam), dibaca nem. (2) Pelog. Sistem urutan nadanya terdiri dari lima (atau tujuh) nada dalam satu gembyang dengan menggunakan pola jarak nada yang tidak sama rata, yaitu tiga (atau lima) jarak dekat dan dua jarak jauh, dengan susunan dan pola interval yang diatur sebagai berikut :

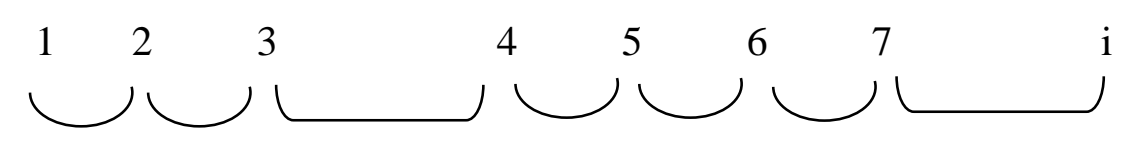

Menurut Sumarto dan Suyuti (1978 : 7), titi berarti tulisan atau tanda, sedangkan laras adalah urutan nada dalam satu gembyangan (1 oktaf) yang sudah tertentu jaraknya atau tinggi rendahnya. Sehingga pengertian titi laras adalah tulisan atau tanda sebagai penyimpulan nada-nada yang sudah tertentu tinggi rendahnya dalam satu gembyang, yang berfungsi: untuk mencatat dan membunyikan gendhing atau tembang, untuk belajar menabuh atau dengan membaca bahasa jawa yaitu: 1 dibaca (siji), 2 (loro), 3 (telu), 4 (papat), 5 (lima), 6 (nem), 7 (pitu). Akan tetapi efisiennya cukup disingkat ji, ro, lu, pat, ma, nem, pi saja.

\section{a. Titi laras slendro}

Titi laras slendro dibagi bermacam-macam pathet (Siswanto 1986 : 15) yaitu:

$\begin{array}{llllllll}\text { Laras slendro pathet sanga } & : 5 & 6 & 1 & 2 & 3 & 5\end{array}$

$\begin{array}{lllllll}\text { Laras slendro pahtet nem } & : 2 & 3 & 5 & 6 & 1 & 2\end{array}$




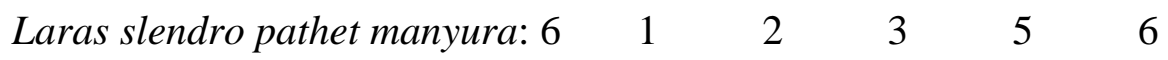

b. Titi laras pelog

Dalam gamelan pelog ada tiga pathet (sistem tangganada pentatonis) yang dapat diciptakan, yaitu laras pelog pathet barang, laras pelog pathet nem, dan laras pelog pathet lima (Sumarto dan Suyuti $1978: 7-8$ ).

Laras pelog pathet barang, nada pokok terdiri dari 6 (nem), 7 (pitu), 2 (loro), 3 (telu), 5 (lima), 6 (nem). Suara $6-7$ intervalnya kecil, 7 - 2 intervalnya besar, $2-3$ intervalnya kecil, $3-5$ intervalnya besar, dan $5-6$ mempunyai interval kecil.

Laras pelog pathet nem, nada pokok terdiri dari 2 (loro), 3 (telu), 4 (papat), 5 (lima), 6 (nem), 1 (siji), 2 (loro). Jarak antara titinada masing-masing: 2 - 3 kecil, 3 - 5 besar, 5 - 6 kecil, 6 - 1 besar, sedangkan 1 - 2 kecil.

Laras pelog pathet lima, nada pokok terdiri dari 5 (lima), 6 (nem), 1 (siji), 2 (loro), 4 (papat) dan 5 (lima). Jarak antara titinada masing-masing: 5 - 6 kecil, $6-1$ besar, $1-2$ kecil, $2-4$ besar, sedangkan $1-2$ kecil.

Martapengrawit (1975:7-23) menyebutkan dalam dunia karawitan jawa gaya Surakarta terdapat 10 bentuk gendhing, yaitu:

\section{a. Lancaran}

Pada bentuk gendhing lancaran dalam satu gongan terdapat 4 gatra. Kethuk ditabuh pada nada hitungan ganjil, kenong ditabuh disetiap akhir gatra, dan kempul ditabuh pada nada genap setelah gatra pertama.

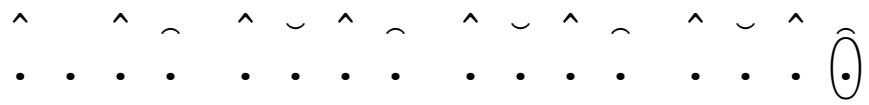


b. Gangsaran

Pada bentuk gendhing gangsaran dalam satu gongan terdapat 8 thuhukan balungan, 3 kempulan, dan 4 kenongan.

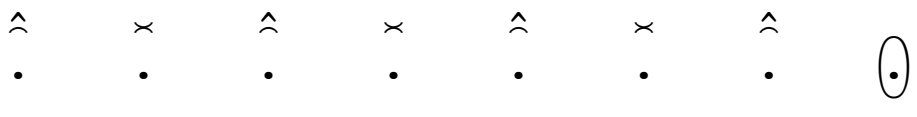

c. Srepegan

Pada bentuk gendhing srepegan, kethuk dipukul pada hitungan genap dan selalu mengambil nada akhir pada setiap gatra. Sedangkan kempul dipukul pada nada terakhir setiap gatra dan jumlah thuthukan balungan dalam satu gongan tidak tentu.

d. Sampak

Pada bentuk gendhing sampak dalam satu gongan terdapat 8, 12, 16 thuthukan balungan. Tiap 4 thuthukan balungan disebut gatra. Kethuk dipukul bersama kenong selang satu nada, sedang kempul dipukul tepat pada nada genap bersama kenong.

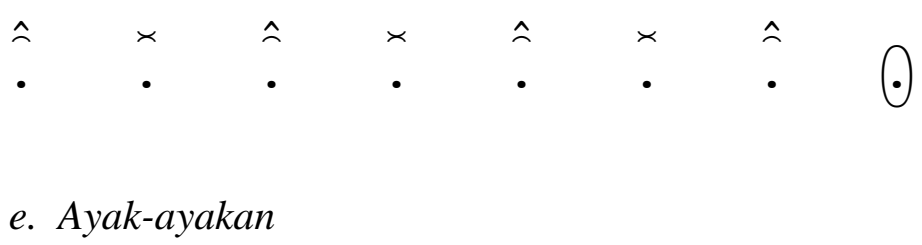

Pada bentuk gendhing ayak-ayakan, kethuk dipukul diantara pukulan kenong dan kempul. Kenong dipukul pada nada hitungan genap dan pada akhir gatra. Kempul dipukul pada akhir gatra dan gong dipukul pada setiap akhir kalimat lagu. 


\section{f. Kemuda}

Pada bentuk gendhing kemuda, kethuk dipukul pada setiap nada hitungan ganjil, kenong ditabuh pada setiap nada hitungan genap pada setiap akhir gatra. Kempul dipukul pada setiap akhir 2 gatra, dan gongan dipukul pada setiap akhir lagu.

\section{g. Ketawang}

Pada bentuk gendhing ketawang, dalam satu gongan terdiri dari 16 thuthukan balungan atau 4 gatra. Kempyang dipukul pada nada hitungan ganjil, kethuk dipukul pada di sela-sela kempyang, kenong dipukul pada akhir gatra ke-2 dan ke4, kempul ditabuh pada akhir gatra ke-3.

\section{h. Ladrang}

Pada bentuk gendhing ladrang, dalam satu gongan terdiri dari 32 thuthukan balungan, atau terdiri dari 8 gatra. Kempyang dipukul pada setiap nada ganjil, kethuk dipukul diantara kempyang, kenong dipukul pada akhir gatra nada yang genap, dan kempul dipukul pada akhir gatra ke-3, ke-5, dan ke-7.

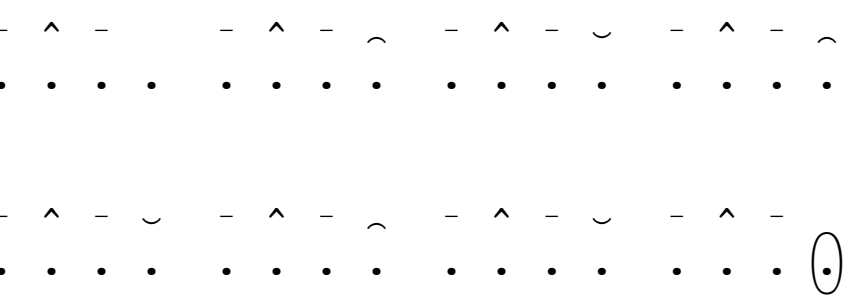


i. Merong

Merupakan gendhing lanjutan dari bentuk gendhing tertentu dan irama lancaran untuk menuju irama dados, yang terdiri dari kethuk 2 (loro atau kalih) kerep, kethuk 2 arang (atau awis), kethuk 4 (papat atau sekawan) kerep, dan kethuk 8 (wolu) kerep yang hanya terdapat pada repertoar gendhing pelog.

j. Inggah

Merupakan gendhing lanjutan dari bentuk gendhing tertentu dan irama lancaran untuk menuju irama dados, yang terdiri dari kethuk 2 (loro atau kalih), kethuk 4 (papat atau sekawan), kethuk 8 (wolu), dan kethuk 16 (nembelas) yang hanya terdapat pada repertoar gendhing pelog.

Keterangan:

$$
\begin{array}{ll}
\cdot & =\text { satu thuthukan atau satu pukulan } \\
\text { gatra } & =\text { empat thuthukan } \\
\cdot & =\text { kenong } \\
\text { - } & =\text { kethuk } \\
- & =\text { kempul } \\
- & \\
- & =\text { kempyang } \\
\text {. } \quad=\text { gong }
\end{array}
$$




\subsection{Seni dan Kesenian}

Menurut Ki Hajar Dewantara, seni merupakan hasil keindahan sehingga dapat menggerakkan perasaan indah orang yang melihatnya, oleh karena itu perbuatan manusia yang dapat memengaruhi dapat menimbulkan perasaan indah itu disebut seni. Seni adalah proses dari manusia. Oleh karena itu, seni sangat susah untuk dijelaskan dan dinilai. Seni diciptakan oleh manusia itu sendiri sehingga menimbulkan keindahan.

Seni dan masyarakat merupakan dua konsep yang masing-masing punya masalah dan punya kepentingan sendiri, walaupun diantara keduanya terdapat hubungan yang tidak dapat dipisahkan. Plato, filsuf yang terkenal dengan sebutan dewa estetika, mengatakan: bahwa seni dan masyarakat merupakan hubungan yang tak terpisahkan; seni integral dengan masyarakatnya; satu konsep yang tidak terpisahkan; baik seni dan masyarakat terwujud diantaranya hubungan tak terpisahkan antara manusia dan lingkungannya. Seni memiliki pengertian yang berbeda pada orang yang berbeda dan dalam waktu yang berbeda.

Menurut Kuntjaraningrat (1993:5), kesenian adalah suatu kompleks dari ideide, gagasan, nilai-nilai, norma-norma, dan peraturan dimana kompleks aktivitas dan tindakan berpola dari manusia dalam masyarakat biasanya berwujud bendabenda hasil manusia. Dengan kata lain, kesenian merupakan bagian dari budaya yang merupakan sarana untuk mengekspresikan rasa keindahan.

\subsection{Kesenian Tradisional}

Menurut wikipedia, seni tradisional adalah unsur kesenian yang menjadi bagian hidup masyarakat dalam suatu kaum/puak/suku bangsa tertentu. 
Jazuli (2008:62) mengemukakan bahwa, kesenian tradisional kerakyatan merupakan cermin ekspresi dari masyarakat yang hidup di luar istana atau dari kalangan rakyat jelata.

Menurut Rohidi (dalam Sarastiti, 2000:101) mengatakan bahwa kesenian tradisional atau biasa dikatakan kesenian asli Indonesia, terbagi menjadi berpuluh puluh kesenian daerah yang terdiri dari seni rakyat dan seni klasik. Seni rakyat berkembang secara beragam di desa-desa dan seni klasik berkembang terutama di pusat-pusat pemerintahan kerajaan (tempo dulu) Indonesia.

Kesenian tradisional di Indonesia tumbuh sebagai bagian dari kebudayaan masyarakat. Setiap kesenian tradisional mempunyai sifat dan ciri-ciri khusus, seperti yang dikemukakan oleh Kayam dan Bastomi (1998:95-96): (1) Kesenian tradisional bukan merupakan hasil kreativitas individu, tetapi tercipta secara anonim bersama kolektivitas masyarakat yang menunjang. (2) Kesenian tradisional mempunyai jangkauan yang terbatas pada lingkungan atau culture yang menunjang. (3) Kesenian tradisional merupakan cerminan dari suatu culture yang berkembang sangat perlahan karena dinamika masyarakat penunjangnya memang demikian. (4) Kesenian tradisional merupakan bagian dari suatu cosmos yang bulat dan tidak terbagi-bagi dalam pengotakan spesialisasi.

Dengan demikian, kesenian tradisional adalah seni yang tumbuh dan berkembang di suatu daerah tertentu, diturunkan secara turun temurun dari nenek moyang, tidak diketahui siapa penemu dan penciptanya, bersifat merakyat, dan digunakan sebagai cara untuk bertahan hidup sehingga menjadi ciri khas dari daerah itu sendiri. 


\subsection{Kesenian Barongan Blora}

Blora merupakan kota kecil di kawasan timur wilayah Jawa Tengah memiliki berbagai potensi kesenian yang masih lekat dengan kegiatan ritual. Hal ini dikarenakan Blora merupakan daerah yang penduduknya sebagian besar memiliki kepercayaan animisme, dinamisme, serta kepercayaan terhadap binatang totem. Kepercayaan ini merupakan sisa budaya primitif yaitu suatu kebudayaan yang masih tergantung dengan alam, sehingga menganggap alam masih memiliki kekuatan. Sikap yang lekat dengan alam ini yang menimbulkan adanya kepercayaan animisme dan dinamisme, sehingga manusia melakukan kegiatankegiatan ritual untuk menyeimbangi alam agar tidak mengganggu kehidupannya. Diantara kesenian yang masih lekat dengan kegiatan ritual adalah seni barongan, kehadirannya dipercaya sebagai pelindung masyarakat.

Kesenian Barong atau lebih dikenal dengan Kesenian Barongan merupakan kesenian khas Jawa Tengah. Akan tetapi dari beberapa daerah yang ada di Jawa Tengah, Kabupaten Blora lah yang secara kuantitas keberadaannya lebih banyak bila dibandingkan dengan kabupaten lainnya.

Seni Barong merupakan salah satu kesenian rakyat yang amat populer dikalangan masyarakat Blora, terutama masyarakat pedesaan. Di dalam Seni Barong tercermin sifat-sifat kerakyatan, kesederhanaan, kasar, keras, kompak, dan keberanian yang dilandasi kebenaran.

Tentang Barongan Blora tidak ada berita tertulis. Maka dari itu untuk mengetahui sejarahnya dilakukan dengan mendengarkan cerita dari generasi tua serta legenda maupun mitos-mitos yang masih hidup di masyarakat Blora. Satu 
diantara mitos itu adalah sebuah makam tua yang ada diantara Desa Beran dan Desa Kamolan, tepatnya di Kelurahan Mlangsen Kecamatan Kota Blora. Menurut tradisi lisan masyarakat setempat, makam tersebut adalah makam Singa Lodra atau Jaka Lodra (Singa Lodra identik dengan tokoh Jaka Lodra yang ada dalam cerita barongan. Jaka Lodra adalah tokoh yang mengalahkan Singabarong. Di Blora, Jaka Lodra dalam cerita barongan disebut Genderuwon, sebab wajah Jaka Lodra hitam menakutkan seperti genderuwo/ makhluk halus yang menakutkan. Kehadirannya Jaka Lodra dalam barongan selalu membawa pedang). Makam ini selalu dikaitkan dengan seni barong. Hal ini terbukti setiap organisasi yang menginginkan barongannya memiliki "daya keramat" seperti Singa, harus dimintakan berkah pada makam tersebut. Selain itu di makam tersebut dipercaya sering muncul Harimau besar jelmaan mbah Singa Lodra. Keyakinan ini semakin memperkuat kepercayaan masyarakat terhadap seni barong yang masih dianggap memiliki kekuatan magis.

Mitos lain yang mengesahkan Barongan asli sebagai kesenian Blora adalah tradisi lisan tentang Barongan merupakan jelmaan orang bernama Gembong Amijaya, yang ada dalam cerita Malat Panji, yang bersumber di Kerajaan Kediri. Mitos ini dikuatkan pula dengan tradisi lisan tentang Ibunya Candra Kirana yang pernah tinggal di Blora. Candra Kirana atau Sekartaji merupakan salah satu tokoh dalam cerita Panji yang terkait dengan cerita tentang Gembong Amijaya yang merupakan Adipati kepercayaan raja Kediri sebagai penjaga perbatasan di hutan Wengker. Tentang ibunya Candra Kirana dikuatkan pula oleh tulisan T.S. Raffles dalam bukunya yang berjudul The History of Java yang menyebutkan bahwa kuda 
Lalean menyertai ibunya Candra Kirana menuju ke barat sampai ke Blora. Ia menjadi penguasa baru di Mendang Kamulan. Mendang Kamulan atau Medang Kamulan Suripan Sadi Hutomo mengatakan, menurut legenda rakyat di Blora, bahkan legenda-legenda dan babad di luar Blora, daerah Blora dulu bernama Mendang Kamulan atau Medang Kamulan. Kesenian Barongan di Blora secara historis tidak dapat ditentukan dengan pasti, namun sedikitnya ada beberapa tulisan dan tradisi lisan yang dapar digunakan sebagai sumber. Selanjutnya legenda menceritakan, pada waktu itu Belanda mencari Naya Gimbal sebagai pengikut Diponegoro dengan cara membunuh orang-orang desa Sambeng. Pada waktu itu orang-orang desa Sambeng sedang mengiring temanten. Mereka naik dokar dengan diiringi Barongan, jedor, dan terbang. Orang-orang ini ditembaki oleh Belanda. Tempat orang-orang Sambeng tergeletak (Jawa, blasah) diberi nama desa Besah. Mengkaji legenda tersebut dapat dipahami bahwa sekitar tahun 1830 Masehi pertumbuhan Barongan di Blora telah menduduki posisi penting dalam kehidupan masyarakat. Hal ini terlihat penggunaan Barongan dalam acara ritual arak-arakan pengantin pada masa Naya Gimbal, yang terjadi masa perang Diponegoro (1925-1830).

Memahami perkembangan Barongan di atas, dapat diketahui pertumbuhan Barongan pada awalnya merupakan bentuk seni ritual sebagai warisan kepercayaan totemisme, yang sampai saat ini masih dapat dilihat dalam tradisi masyarakat seperti ruwatan, arak-arakan pengantin, arak-arakan anak khitan, dan lamporan. Selanjutnya menjadi sebuah seni tontonan yang lepas dari ikatan ritual 
yang dianggap sakral. Walaupun demikian Barongan oleh masyarakat masih tetap dianggap memiliki daya keramat (Slamet, 2003:9-10).

Kesenian Barongan berbentuk tarian kelompok yang menirukan keperkasaan gerak seekor Singa Raksasa. Peranan Singo Barong secara totalitas didalam penyajian merupakan tokoh yang sangat dominan, disamping ada beberapa tokoh yang tidak dapat dipisahkan yaitu bujangganong, pujonggo anom, joko lodro, genderuwo, pasukan berkuda, reog, noyontoko, untub. Selain tokoh tersebut, pementasan kesenian barongan juga dilengkapi dengan beberapa perlengkapan yang berfungsi sebagai instrumen musiknya, antara lain: (1) Kendhang yang disebut juga pamurbo irama, menentukan bentuk gendhing, mengatur irama dan jalannya lagu, serta mengatur mandeg dan menyuwuk gendhing; (2) Kethuk yang disebut juga pemangku irama, menguatkan kendhang dalam menentukan bentuk gendhing; (3) Bonang yang disebut pemangku lagu, tugasnya menghias lagu; (4) Kenong disebut sebagai pemangku irama yang digunakan untuk menentukan batas-batas gatra di dalam bentuk gendhing; (5) Saron disebut sebagai pemangku lagu, tugasnya sebagai pola dari lagu atau balungan; (6) Demung tugasnya sama dengan saron; (7) Kempul menentukan batas-batas gatra berdasarkan bentuk gendhingnya.

Adapun fungsi barongan bagi masyarakat Blora antara lain: (1) Keperluan upacara tradisional seperti tradisi upacara sedhekah bumi yang sering dilakukan oleh masyarakat agraris setelah musim panen, sebagai ungkapan rasa syukur dan selamatan atas keberhasilannya dalam melakukan panen dengan harapan mendapat lindungan dari Tuhan; mengarak Barongan pada acara khitanan atau 
sunat yang diharapkan untuk menambah kewibawaan anak yang sunat dan mendapat lindungan dari bala yang akan menggunakannya, terkait dengan kepercayaan Barongan memiliki kekuatan magis proteksi; mengarak Barongan pada upacara pernikahan dikarenakan oleh adanya kepercayaan dan anggapan bahwa calon pengantin nantinya seperti pamornya pengantin Raden Panji dan Candra Kirana, dengan harapan pengantin memiliki kesetiaan seperti Raden Panji dan Dewi Candra Kirana dimana dengan berbagai cobaan yang memisahkan mereka akhirnya bertemu kembali; dan sebagai penangkal wabah seperti pada tradisi lamporan, mengarak Barongan mengelilingi desa dengan maksud agar masyarakat terhindar dari mala petaka. (2) Keperluan tontonan atau hiburan dimana Seni Barongan sebagai seni tontonan digarap sedemikian rupa sesuai dengan keinginan masyarakat pendukungnya dan hanya bersifat menghibur tanpa terkait peristiwa-peristiwa yang dianggap penting atau sakral (Slamet, 2003:14$15)$.

Dari kenyataan di atas, dapat kita simpulkan bahwa Seni Barong bukan hanya sebagai pertunjukan atau hiburan semata, melainkan merupakan ritus yang sifatnya religio magis untuk menanggapi keadaan alam dan untuk menguasainya.

Elemen-elemen pertunjukan Kesenian Barongan:

1) Bentuk penyajian

Seni Barongan Blora adalah milik masyarakat secara kolektif. Ciri kesenian tradisional kerakyatan adalah sederhana, tetapi bagaimana yang sederhana itu bisa menjadi menarik. Jelas bahwa sebagai bentuk seni kerakyatan memiliki daya tarik tersendiri dalam penyajiannya. Untuk itu barongan memiliki unsur-unsur yang 
mendukung sebagai sebuah bentuk seni pertunjukan secara utuh. Kesenian ini dapat disajikan dalam bentuk pertunjukan tanpa cerita maupun dalam bentuk drama.

Pertunjukan Barongan lepas tanpa cerita dapat berbentuk atraksi tunggal macanan/kucingan dan dapat juga berbentuk pawai/arak-arakan. Bentuk penyajian yang dipertunjukkan secara arak-arakan (pawai) maupun yang disajikan di tempat yang permanen/panggung (biasanya berbentuk drama) memiliki unsur yang berbeda, namun pada dasarnya sama. Oleh karena dalam arak-arakan Barongan juga berlatar belakang cerita yang sama seperti pada drama, hanya penyajiannya tidak berbentuk cerita. Dalam bentuk ini cenderung menampilkan tokoh-tokoh cerita tersebut, namun tokoh yang ditampilkan tidak seluruhnya. Penampilan tokoh ini lebih menekankan pada peristiwa ketika Jaka Lodra mengalahkan Singabarong, sehingga hanya menampilkan tokoh Singabarong dan Gendruwon.

Selain mengambil peristiwa kekalahan Singabarong dengan Jaka Lodra/ Gendruwon, pawai sering dikaitkan dengan peristiwa arak-arakan pengantin Raden Panji. Penyajian arak-arakan ini cenderung menampilkan semua tokoh yang ada dalam cerita. Bentuk pawai seperti di atas hanya berbentuk arak-arakan biasa, tanpa menampilkan alur cerita.

Pertumbuhan Barongan selanjutnya bentuk arak-arakan dengan atraksi yang menggambarkan alur cerita seperti ini cenderung menampilkan semua tokoh yang ada. Penyajian atraksi biasanya dilakukan pada setiap perempat jalan. Arak-arakan tersebut berhenti sejenak, kemudian menyajikan cuplikan adegan seperti perang 
antara Singabarong dengan Jaka Lodra/ Gendruwon, perang antara Pujangga Anom dengan Singabarong, dan cuplikan-cuplikan adegan lain sesuai dengan alur cerita.

Bentuk Penyajian Kesenian Barongan Blora terdiri dari: (1) Pemain merupakan bagian dari aspek bentuk pertunjukan yang di dalamnya terdapat oranorang yang berperan penting dalam sebuah pementasan seni pertunjukan. Dalam hal ini, pemain yang ada dalam Kesenian Barongan ini adalah Barongan, yang berbentuk kepala singa dengan rambut berwarna hitam lebat dan kaku dari ijuk; Genderuwo, tokoh ini yang biasanya membawa pedang-pedangan yang terbuat dari kayu,berpakaian rombeng, menggunakan topeng berwarna hitam dengan mata membelalak; Penthul, tokoh ini memakai topeng dengan hidung besar dan panjang; Nggainah, tokoh ini menggunakan baju wanita dan memakai topeng dengan bibir yang merot kesamping; Penari Reog, terdiri dari perempuanperempuan yang menaiki kuda lumping. (2) Watak Tokoh yang terdiri dari Barongan berwatak galak, bringas, menyeramkan, lincah, dan sering menakutnakuti penonton; Genderuwo berwatak galak dan seram; Penthul berwatak galak, dan suka menakut-nakuti anak-anak; Nggainah berwatak lucu dan dianggap sebagai lelucon dari kesenian Barongan tersebut; Reogan adalah berupa tarian penggembira. (3) Busana/ Kostum yang terdiri dari Barongan mengenakan kostum kepala singa dari kayu berukuran besar dan kain panjang loreng-loreng seperti kulit harimau; Genderuwo mengenakan celana warok hitam selutut, dan baju rombeng, memakai topeng kayu dengan mata membelalak menyeramkan, serta rambut yang terbuat dari ijuk acak-acakan; Penthul memakai topeng kayu 
dan celana warok hitam dibawah lutut; Nggainah mengenakan baju wanita (daster, kebaya), topeng kayu dengan bibir merot; Reogan mengenakan atasan kaos dan diberi rompi, bawahannya celana dibawah lutut lalu diberi balutan jarit.

2) Urutan Penyajian

Lama pentas Barongan tergantung permintaan orang yang punya hajat. Seperti telah diuraikan di atas, bentuk penyajian dibagi menjadi dua bentuk yaitu dalam bentuk cerita atau drama dan dalam pawai atau arak-arakan. Urutan penyajian dalam arak-arakan atau pawai biasanya Barongan berada di depan arakarakan, yang urutannya Gendruwon, Barongan, musik pengiring baru disusul arak-arakan lainnya sesuai peristiwa arak-arakan tersebut. Apabila arak-arakan itu menampilkan semua tokoh yang ada dalam cerita, tokoh-tokoh tersebut berada di depan Barongan.

Berbeda dengan penyajian Reog Barongan lebih mengutamakan isi cerita sehingga penyajiannya memerlukan penggarapan yang mendukung isi dramatiknya. Penyajian dalam bentuk ini memiliki dua bentuk yaitu penyajian dalam atraksi trance dan penyajian tanpa atraksi trance. (1) Penyajian Reog Barongan tanpa trance yang pertama adalah pra-tontonan yang biasanya diisi dengan tabuhan lagu-lagu atau gendhing-gendhing pembuka; kedua adalah lawak yang berupa tarian dan dialog antara Nayantaka, Untub, dan Gainah; yang ketiga adalah masuknya Barongan dalam pentas ditandai dengan musik barongan; keempat adalah tarian oleh penari reog/ jaran, dan terdapat juga satu adegan khas yaitu nyandra yang biasa dibawakan oleh Gendruwon; yang kelima adalah inti cerita dimana terjadi pertemuan antar tokoh kemudian terjadi peperangan dan 
penyelesaian masalah; keenam adalah atraksi tari Bali yang dilakukan setelah Raden Panji dapat memenuhi permintaan Dewi Sekartaji dimana tari Bali yang dimaksud tidak seperti tari yang ada di Pulau Bali, melainkan sebuah bentuk tari semacam senam lantai; yang terakhir adalah tari Gandariya yaitu tarian semacam akrobatik diiringi dengan gendhing Gandariya. (2) Penyajian Reog Barongan dengan trancel kerasukan yang pertama adalah pra-tontonan seperti halnya penyajian reog barongan tanpa trance, hanya bedanya pada bagian ini sesaji harus sudah dipersiapkan terlebih dahulu, kemudian dikepung oleh pemain Barongan dan doa dipimpin oleh pawang; kedua adalah pementasan Barongan yang menggambarkan peperangan dimana pawang membacakan mantra agar pemain mau demonstrasi makan beling/ pecahan kaca, mengupas kelapa dengan gigi, makan padi dan sebagainya.

3) Tema Cerita

Barongan merupakan bentuk pertunjukan topeng yang mengambil cerita Panji, hal ini terkait dengan kebiasaan cerita, yang dipakai dalam pertunjukan topeng di Jawa. Adapun cerita Panji yang digunakan sudah dibahas pada halaman sebelumnya.

4) Tari dan Pola Lantai

Bentuk tari Barongan belum ada standrat gerak atau ragam gerak yang baku. Hal ini dikarenakan merupakan bentuk seni kerakyatan yang didukung oleh pola hidup rakyat yang sederhana, sehingga menimbulkan ekspresi seni yang sederhana dan bersifat komulatif milik bersama. Sifat gerak spontan dan 
improfitatif menirukan tingkah laku binatang yang dipercaya sebagai binatang totem protektif.

5) Musik Iringan

Iringan yang digunakan dalam pertunjukan Barongan tidak selengkap pada seni pertunjukan lainnya, tetapi masih menggunakan instrumen gamelan berlaras slendro. Adapun gendhing yang digunakan antara lain Ponoragan (adegan Barongan), Srepegan (Perangan), Sekar Telo (atraksi tari Bali), dan lancaran Gandariya (tari Gandariya).

Berikut adalah notasi gendhing Ponoragan:

$\begin{array}{llllllll}2 & 2 & 2 & 2 & 2 & 2 & 2 & 2 \\ & 5 & \cdot & 6 & \cdot & 5 & . & 6\end{array}$

Keterangan:

Bonang nada 2 (loro) berfungsi sebagai kethuk

Bonang nada 5 (lima) dan 6 (enem) berfungsi sebagai melodi

6) Kostum (Busana) dan Tata Rias

Busana atau kostum dan rias akan menunjukkan watak karakter peran yang dibawakan, selain itu merupakan aspek pendukung artistik dan estetik penyajian seni. Kostum para pemain sudah dijelaskan pada halaman sebelumnya.

7) Tempat Pertunjukan

Barongan sebagai bentuk kesenian rakyat dalam penyajiannya diselenggarakan di arena terbuka, dalam hal ini dapat diselenggarakan di halaman 
rumah atau di lapangan terbuka, sebab kesenian ini pada awalnya merupakan bentuk seni ritual, kemudian menjadi seni barangan.

Perkembangan selanjutnya kesenian dipertunjukkan di panggung sebagai bentuk seni tontonan panggung. Tempat pertunjukan disesuaikan event atau kepentingan penyelenggaraan peristiwa. Tempat pertunjukan memperhitungkan jumlah pemain, kenyataan ini menunjukkan bahwa tempat yang digunakan sebagai pentas dalam seni ritual maupun seni barangan telah mempertimbangkan garapan. Walaupun pada saat itu tidak terpikirkan tentang pola garap, tetapi kepentingan yang diutamakan.

Berbeda dengan seni panggung telah memperhitungkan pola garap dengan mempertimbangkan elemen-elemen pertunjukan termasuk tempat pentas, sehingga dapat memberi daya dukung tentang garapan baik dari sisi tataan maupun keindahan sajian secara total.

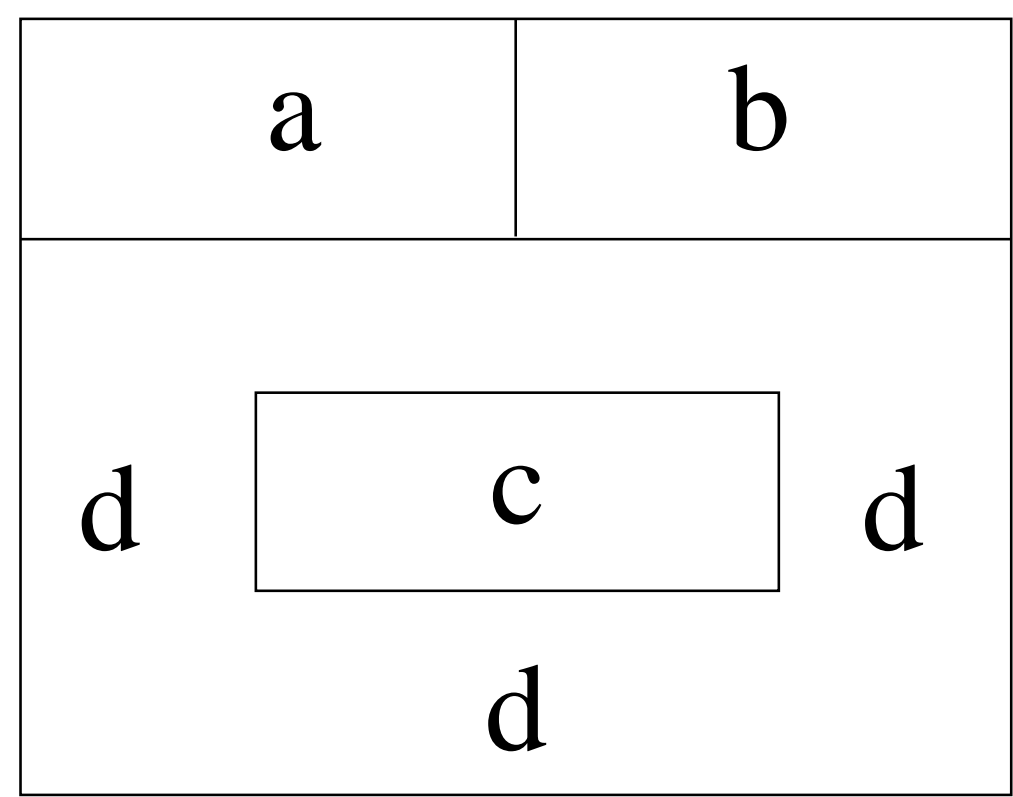

Gambar 2.1 Tempat Pentas Bentuk Arena Sumber: Barongan Blora (Slamet M.D., 2003) 
Keterangan:

a. Tempat penabuh dan penari (apabila penari merangkap penabuh)

b. Tempat penari (apabila penari tidak merangkap)

c. Arena pentas

d. Tempat penonton

\subsection{Tinjauan Pustaka}

Penelitian yang komprehensif tentang kajian yang sama, yaitu laporan yang ditulis oleh Danuardi Wijaya dengan judul Pertunjukan Musik Calung sebagai Pengiring Kesenian Tari Lengger di Desa Karanggedang Kecamatan Sidareja Kabupaten Cilacap pada tahun 2012. Di dalam tulisan tersebut penulis menjelaskan mengenai suatu rangkaian musik calung untuk mengiringi kesenian tari lengger yang meliputi gendhing Banyumas, lagu campursari, dan lagu berirama dangdut.

Dian Kristine Novitasari dalam laporannya yang berjudul Bentuk Musik iringan Kesenian Dayakan di Kota Magelang pada tahun 2013. Penelitian tersebut menghasilkan kesimpulan bahwa pola iringan yang digunakan dalam kesenian dayakan menggunakan instrumen seperti kesenian barongan sebagai musik pengiring.

Aditya Wishnu Wardhana dalam skripsinya yang berjudul Musik Pendukung Kesenian Jaran Debog di Dusun Suruhan Desa Keji Kecamatan Ungaran Barat Kabupaten Semarang pada tahun 2014. Dalam laporan tersebut dijelaskan tentang musik pendukung kesenian jaran debog yang hampir sama 
dengan pertunjukan musik kesenian kuda lumping pada umumnya dengan urutan bentuk pertunjukannya adalah: 1. Srepek Lasem laras slendro patet nem. 2. Palaran Pangkur patet nem. 3. Lelagon Kuda Debog laras pelog nem. 4. Lancaran Bendrong laras patet manyuro. 5. Sampak. 6. Iringan Musik. 7. Sampak. 8. Iringan Musik. 9. Lelagon Kuda Debog Laras pelog nem. 10. Sampak. 11. Palaran Pangkur Patet nem. 12. Sampak. 13. Srepek Lasem laras slendro patet nem. 14. Sayonara.

\subsection{Kerangka Berfikir}

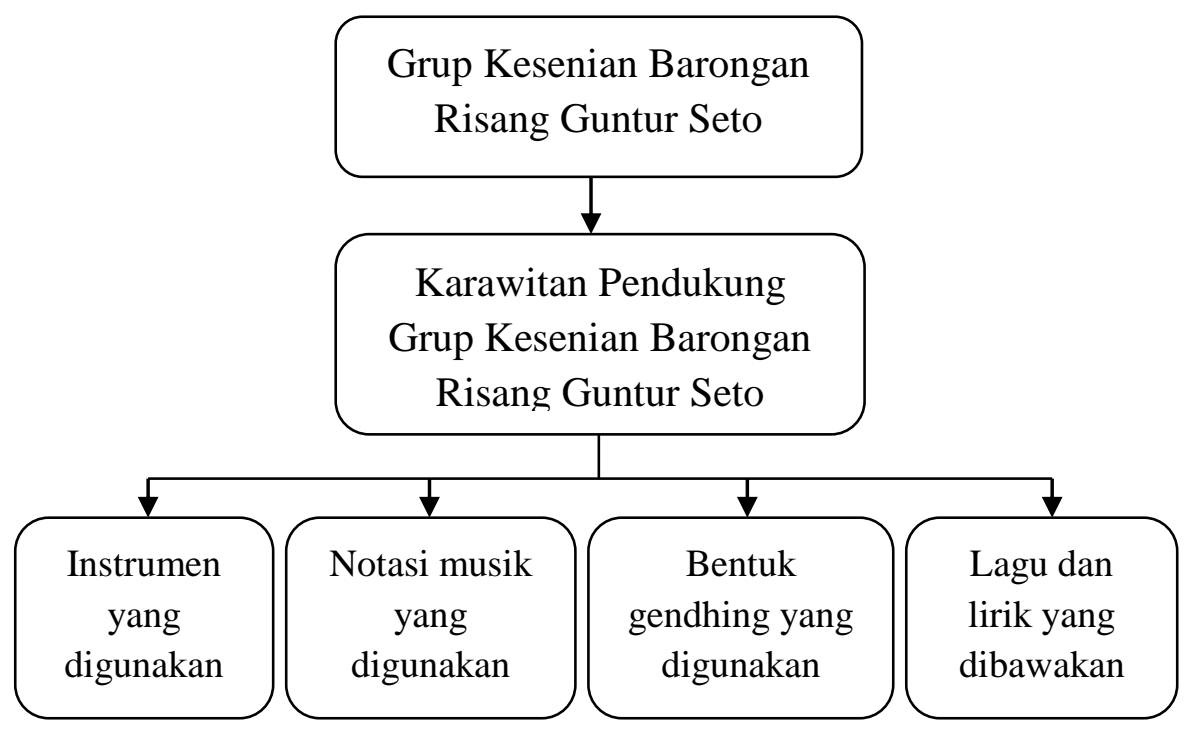

Bagan 2.1 Kerangka Berfikir (Oleh: Reni Wulansari 2015)

Pada bagan 2.1, berpangkal dari Grup Kesenian Barongan Risang Guntur Seto, peneliti melakukan penelitian guna mendapatkan informasi mengenai karawitan pendukung grup kesenian barongan Risang Guntur Seto berdasarkan instrumen yang digunakan, notasi yang digunakan, bentuk gendhing yang 
digunakan, lagu dan lirik yang dibawakan, kemudian menganalisis dan menjabarkannya satu per satu

Perkembangan kesenian barongan di Kabupaten Blora telah melahirkan grup Risang Guntur Seto sebagai grup kesenian yang dibanggakan kabupaten Blora karena sudah melalang buana mengikuti berbagai festival, pawai, dan tampil dalam pertunjukan di acara lokal maupun tingkat nasional. Grup ini menampilkan barongan yang digambarkan menyerupai singa besar penguasa hutan diiringi dengan musik pengiring barongan berupa instrumen karawitan antara lain kethuk, kenong, gong, kendhang, dan beberapa instrumen lain berlaras slendro. Musik yang dimainkan oleh grup ini memiliki ciri khas yang terdapat dalam tempo, pola iringan, lagu/gendhing yang dimainkan, dan pola permainan dalam suatu penampilan. Masyarakat setempat pun sangat antusias terhadap keberadaan grup kesenian Risang Guntur Seto dan selalu mengikuti perkembangannya. Pada penelitian ini, kerangka berfikir terfokus pada karawitan pendukung/musik iringan yang digunakan oleh grup kesenian barongan Risang Guntur Seto dalam pertunjukannya. 


\section{BAB 3}

\section{METODE PENELITIAN}

\subsection{Pendekatan Penelitian}

Pendekatan yang digunakan dalam penelitian ini adalah pendekatan karawitanologi. Pendekatan karawitanologi yaitu pendekatan musikal berwarna antropologis. Dua aspek musikologis dan antropologis dipadukan. Musik ditempatkan sebagai objek utama, sekaligus ditemukan dasar relasinya dengan persoalan-persoalan kebudayaan dan masyarakat. Soedarsono menyatakan pendekatan semacam tersebut adalah juga pendekatan multi-disiplin (pendekatan lebih dari satu disiplin, inter-disiplin atau inter-disipliner). Pendekatan karawitanologi sangat efektif digunakan untuk mengidentifikasi masalah karawitan pendukung/ karawitan pengiring kesenian barongan.

Metode penelitian yang digunakan dalam penelitian ini adalah pendekatan deskriptif kualitatif. Menurut Bogdan dan Taylor (1975:5) metodologi kualitatif adalah prosedur penelitian yang menghasilkan data deskriptif berupa kata-kata tertulis atau lisan dari orang-orang dan perilaku yang dapat diamati.

Sejalan dengan definisi tersebut, Kirk dan Miller (1986:9) mendefinisikan bahwa penelitian kualitatif adalah tradisi tertentu dalam ilmu pengetahuan sosial yang secara fundamental bergantung dari pengamatan pada manusia baik dalam kawasannya maupun dalam peristilahannya.

Denzin dan Lincoln (1987) menyatakan bahwa penelitian kualitatif adalah

penelitian yang menggunakan latar alamiah, dengan maksud menafsirkan 
fenomena yang terjadi dan dilakukan dengan jalan melibatkan berbagai metode yang ada. Sehinggga dapat ditarik kesimpulan bahwa penelitian kualitatif adalah penelitian yang bermaksud untuk memahami fenomena tentang apa yang dialami oleh subjek penelitian misalnya perilaku, persepsi, motivasi, tindakan, dll., secara holistik, dan dengan cara deskripsi dalam bentuk kata-kata dan bahasa, pada suatu konteks khusus yang alamiah dan dengan memanfaatkan berbagai metode alamiah.

Metode penelitian kualitatif inilah yang digunakan peneliti untuk mendeskripsikan tentang karawitan pendukung kesenian barongan Risang Guntur Seto di Kabupaten Blora.

Studi kasus adalah merupakan salah satu strategi dalam sebuah penelitian kualitatif. Menurut John W. Creswell (dalam Halimi, 2014), studi kasus merupakan strategi penelitian dimana di dalamnya peneliti menyelidiki secara cermat suatu program, peristiwa, aktivitas, proses, atau sekelompok individu. Kasus-kasus dibatasi oleh waktu dan aktivitas, dan peneliti mengumpulkan informasi secara lengkap dengan menggunakan berbagai prosedur pengumpulan data berdasarkan waktu yang telah ditentukan

Desain penelitian inilah yang digunakan dalam penelitian ini adalah, yaitu kasus pada kesenian barongan Blora Risang Guntur Seto. Peneliti menggunakan desain penelitian studi kasus karena peneliti berusaha memusatkan perhatian pada suatu kasus secara intensif dan rinci yaitu karawitan pendukung/ karawitan pengiring. 


\subsection{Sasaran dan Lokasi Penelitian}

\subsubsection{Lokasi Penelitian}

Peneliti akan mengambil lokasi di Jalan Gunung Wilis Nomor 12A Kelurahan Kunden, Kecamatan Blora, Kabupaten Blora. Alasan pengambilan penelitian di lokasi tersebut karena pertimbangan sebagai berikut: 1) Grup Kesenian Barongan Blora Risang Guntur Seto lahir, tumbuh, dan berkembang di Desa Kunden Blora Jawa Tengah hingga sampai saat ini; 2) Sebagian besar masyarakat Blora memiliki antusias yang tinggi terhadap kesenian barongan Blora khususnya terhadap grup Risang Guntur Seto.

\subsubsection{Sasaran Penelitian}

Sasaran kajian dalam penelitian ini adalah karawitan pendukung kesenian barongan Risang Guntur Seto di Kabupaten Blora. Adapun narasumber dalam penelitian ini adalah pihak-pihak yang bersangkutan dan bertanggung jawab dalam grup kesenian barongan Risang Guntur Seto.

\subsection{Data dan Sumber Data}

Untuk keperluan analisis data, peneliti mencari sumber data penelitian antara lain:

\subsubsection{Data Primer}

Data Primer adalah data yang diperoleh secara langsung dari objek penelitian. Dalam hal ini peneliti mengambil data langsung kepada narasumber yaitu grup kesenian barongan Blora Risang Guntur Seto antara lain ketua grup dan anggota grup guna mendapatkan informasi mengenai musik pendukung/ musik 
pengiring barongan, setelah itu mengolah data tersebut menjadi data-data yang berkaitan dengan penelitian.

\subsubsection{Data Sekunder}

Data sekunder merupakan sumber data penelitian yang diperoleh peneliti secara tidak langsung melalui media perantara atau pihak lain. Dalam hal ini peneliti memperoleh data dari sumber bacaan atau melalui kegiatan studi kepustakaan, membaca jurnal dan contoh laporan tugas akhir yang terkait dengan penelitian. Serta browsing menggunakan internet yang memiliki hubungan dengan masalah yang diteliti oleh penulis.

\subsection{Teknik Pengumpulan Data}

Data akan dikumpulkan dengan teknik :

\subsubsection{Observasi}

Observasi adalah pengamatan yang dilakukan untuk melacak secara sistematis dan langsung mengenai gejala-gejala yang terkait dengan objek penelitian (Pawito 2007:111).

Menurut Sugiyono (2005:64), observasi adalah dasar semua ilmu pengetahuan. Para ilmuwan hanya dapat bekerja berdasarkan fakta mengenai dunia kenyataan yang diperoleh melalui observasi.

Alasan secara metodologis bagi penggunaan teknik pengamatan/ observasi adalah: (1) pengamatan mengoptimalkan kemampuan peneliti dari segi motif, kepercayaan, perhatian, perilaku tak sadar, kebiasaan, dan sebagainya; (2) pengamatan memungkinkan peneliti untuk melihat dunia sebagaimana dilihat 
oleh subjek penelitian, hidup pada saat itu, menangkap arti fenomena dari segi pengertian subjek, menangkap kehidupan budaya dari segi pandangan dan anutan para subjek pada waktu itu; (3) pengamatan memungkinkan peneliti merasakan apa yang dirasakan oleh subjek, sehingga memungkinkan pula peneliti sebagai sumber data; (4) pengamatan memungkinkan pembentukan pengetahuan yang diketahui bersama, baik dari pihaknya maupun dari pihak subjek.

Dalam hal ini, peneliti akan menggunakan teknik pemeranserta sebagai pengamat/ observasi non partisipatif, yaitu peranan peneliti sebagai pengamat dalam hal ini tidak sepenuhnya sebagai pemeranserta tetapi melakukan fungsi pengamatan. Peneliti mengamati sendiri pertunjukan kesenian barongan Risang Guntur Seto dengan fokus karawitan pendukung/ iringannya.

\subsubsection{Wawancara}

Wawancara adalah percakapan dengan maksud tertentu. Jenis wawancara yang dikemukakan oleh Patton (1980:197) sebagai berikut: (a) wawancara pembicaraan informal, (b) pendekatan menggunakan petunjuk umum wawancara, dan (c) wawancara baku terbuka.

Dalam hal ini, jenis wawancara yang dipakai oleh peneliti adalah wawancara pembicaraan informal. Pada jenis wawancara ini pertanyaan yang diajukan sangat bergantung pada pewawancara itu sendiri, tergantung pada spontanitasnya dalam mengajukan pertanyaan kepada narasumber. Hubungan antara pewawancara dan narasumber adalah dalam suasana biasa, wajar. Sedangkan pertanyaan dan jawabannya berjalan seperti pembicaraan biasa dalam kehidupan sehari-hari saja. Bahkan sewaktu proses wawancara berlangsung, 
narasumber tidak menyadari bahwa ia sedang diwawancara. Dalam hal ini peneliti mewawancara beberapa narasumber yaitu ketua grup Risang Guntur Seto, salah satu pemusik grup Risang Guntur Seto, dan seseorang yang pernah menanggap grup Risang Guntur Seto sebagai pengisi acara.

\subsubsection{Dokumentasi}

Menurut Arikunto (1983:188), dokumentasi adalah mencari data yang berasal dari catatan, buku, traskrip, surat kabar, majalah, notulen, dan agenda yang berhubungan dengan objek yang diteliti.

Dalam hal ini peneliti akan mengumpulkan data-data mengenai karawitan pendukung kesenian Barongan di Kabupaten Blora, mendokumentasikan dalam bentuk rekaman pertunjukan kesenian Barongan, yang kemudikan dijabarkan secara deskriptif.

\subsection{Teknik Analisis Data}

Analisis data merupakan proses penyusunan data dengan menelaah seluruh data yang terdiri dari berbagai sumber, yaitu dari wawancara, pengamatan yang sudah dituliskan dalam catatan lapangan, dokumen pribadi, dokumen resmi, gambar, foto, dan sebagainya (Moleong 2007:247).

Analisis data kualitatif (Bogdan \& Biklen 1982) adalah upaya yang dilakukan dengan jalan bekerja dengan data, mengorganisasikan data, memilahmilahnya menjadi satuan yang dapat dikelola, mensintesiskannya, mencari dan menemukan pola, menemukan apa yang penting dan apa yang dipelajari, dan memutuskan apa yang dapat diceritakan kepada orang lain. 
Analisis data kualitatif (Seiddel 1998), prosesnya berjalan sebagai berikut: (1) Mencatat yang menghasilkan catatan lapangan, dengan hal itu diberi kode agar sumber datanya tetap dapat ditelusuri. (2) Mengumpulkan, memilah-milah, mengklasifikasikan, mensintesiskan, membuat ikhtisar, dan membuat indeksnya. (3) Berpikir, dengan jalan membuat agar kategori data itu mempunyai makna, mencari dan menemukan pola dan hubungan-hubungan, dan membuat temuantemuan umum.

Sedangkan dalam hal ini, teknik yang digunakan oleh peneliti adalah: (a) Reduksi Data yang berarti merangkum, memilih hal-hal pokok, memfokuskan pada hal-hal penting, mencari tema dan polanya dan membuang yang tidak perlu (Sugiyono 2006:338); (b) Penyajian Data yang dimaksudkan sebagai langkah pengumpulan informasi yang tersusun dan memberikan kemungkinan adanya penarikan kesimpulan dan pengambilan tindakan (Moleong 2007: 251); (c) Verifikasi atau Penarikan Kesimpulan yaitu merupakan langkah terakhir dalam analisis data yang diharapkan adalah merupakan temuan baru yang sebelumnya belum pernah ada.

Tujuan analisis data kualitatif yaitu agar peneliti mendapatkan makna hubungan variabel-variabel sehingga dapat digunakan untuk menjawab masalah yang dirumuskan dalam penelitian. Hubungan antar semantis sangat penting karena dalam analisis kualitatif, peneliti tidak menggunakan angka-angka seperti pada analisis kuantitatif. Prinsip pokok teknik analisis data kualitatif ialah mengolah dan menganalisis data-data yang terkumpul menjadi data yang sistematik, teratur, terstruktur dan mempunyai makna. 


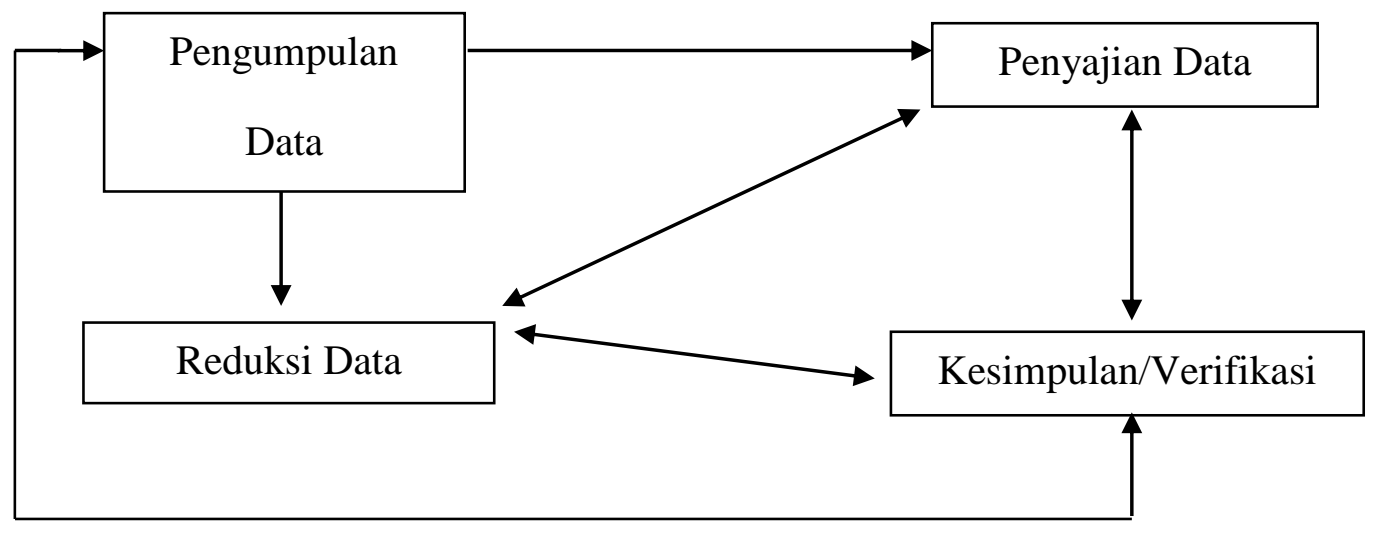

Bagan 3.1 Analisis Data Kualitatif

Sumber: Analisis Data Kualitatif (Miles \& Huberman dalam Sumaryanto, 2010:106)

\subsection{Teknik Pemeriksaan Keabsahan Data}

Untuk menetapkan keabsahan data dalam penelitian kualitatif diperlukan pemeriksaan. Pelaksanaan teknik pemeriksaan didasarkan atas sejumlah kriteria tertentu. Kriteria/standar keabsahan data kualitatif yang penulis pergunakan dalam penelitian ini adalah derajad kepercayaan (credibility). Kriteria ini menuntur penelitian kualitatif agar dapat dipercaya oleh pembaca yang kritis dan dapat dibuktikan oleh orang-orang yang menyediakan informasi yang dikumpulkan selama penelitian berlangsung (Wagiman, 2011:51).

Dalam penelitian ini, peneliti akan menggunakan teknik triangulasi, yaitu pengecekan derajat kepercayaan beberapa sumber data, agar hasil upaya penelitian itu benar-benar dapat dipertanggungjawabkan dari segala segi. Triangulasi adalah verifikasi penemuan melalui informasi dari berbagai sumber dan menggunakan multi metode dalam pengumpulan data. Untuk menguji keabsahan data dipergunakan triangulasi data. Pengujian dilakukan dengan cara: 
(1) membandingkan data hasil wawancara dengan kepala sekolah dan guru seni musik, (2) membandingkan data hasil observasi dengan data hasil wawancara dengan guru seni musik, dan (3) membandingkan hasil wawancara dengan dokumen yang ditemukan (Moleong dalam Wagiman, 2011:51).

Trianggulasi merupakan teknik pengecekan keabsahan data yang didasarkan pada sesuatu diluar data untuk keperluan mengecek atau sebagai pembanding terhadap data yang telah ada (Moleong,2004). Trigulasi yang digunakan adalah trigulasi dengan sumber, yaitu membandingkan data hasil observasi, hasil pekerjaan siswa dan hasil wawancara terhadap subjek yang ditekankan pada penerapan metode bantuan alat pada efektif membaca. Ketekunan pengamatan dilakukan dengan teknik melakukan pengamatan yang diteliti, rinci dan terus menerus selama proses pembelajaran berlangsung yang diikuti dengan kegiatan wawancara secara intensif terhadap subjek agar data yang dihasilkan terhindar dari hal-hal yang tidak diinginkan. Pengecekan teman sejawat/kolega dilakukan dalam bentuk diskusi mengenai proses dan hasil penelitian dengan harapan untuk memperoleh masukan baik dari segi metodologi maupun pelaksanaan tindakan. 


\section{BAB 4}

\section{HASIL PENELITIAN DAN PEMBAHASAN}

Pada hasil penelitian ini akan dikemukakan gambaran umum lokasi penelitian, sejarah grup kesenian barongan Blora Risang Guntur Seto, susunan pengurus grup Risang Guntur Seto, dan penyajian kesenian barongan Risang Guntur Seto yang meliputi persiapan pemain dan urutan penyajian karawitan pendukung kesenian barongan Risang Guntur Seto.

Gambaran umum lokasi penelitian menguraikan tentang lokasi grup kesenian barongan Blora Risang Guntur Seto berada berikut dengan denah lokasinya. Bagian sejarah grup kesenian barongan Blora Risang Guntur Seto menguraikan tentang bagaimana awal mula grup ini berdiri dan mengenai orangorang yang berada di belakangnya. Dalam susunan pengurus grup ditampilkan nama-nama orang yang turut berperanserta dalam kegiatan yang dilakukan grup kesenian barongan Risang Guntur Seto. Penyajian kesenian barongan Risang Guntur Seto menguraikan tentang persiapan pemain sebelum pertunjukan dimulai dan urutan penyajian karawitan pendukung kesenian barongan itu sendiri dari awal pertunjukan sampai akhir pertunjukan.

\subsection{Gambaran Umum Lokasi Penelitian}

Kabupaten Blora adalah kabupaten di Provinsi Jawa Tengah. Ibukotanya adalah Blora, sekitar $127 \mathrm{~km}$ sebelah timur Semarang. Berada di bagian timur Jawa Tengah, Kabupaten Blora berbatasan langsung dengan Provinsi Jawa Timur. 
Kabupaten ini berbatasan dengan Kabupaten Rembang dan Kabupaten Pati di utara, Kabupaten Tuban dan Kabupaten Bojonegoro (Jawa Timur) di sebelah timur, Kabupaten Ngawi (Jawa Timur) di selatan, serta Kabupaten Grobogan di barat.

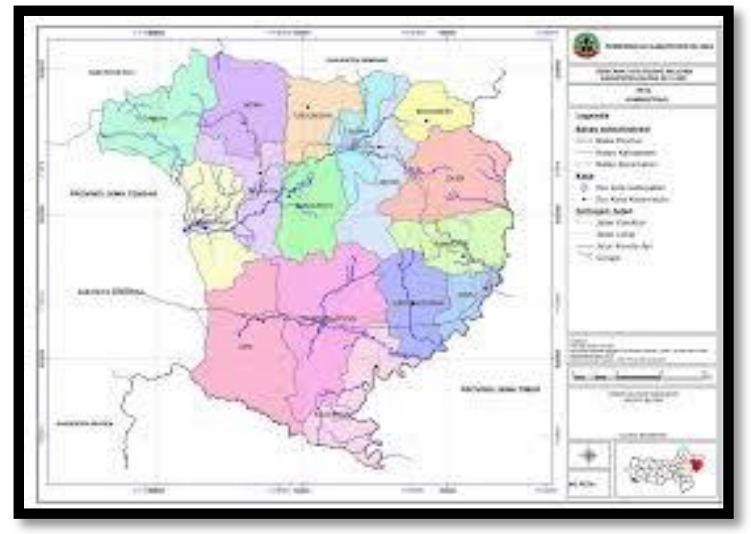

Gambar 4.1 Peta Kabupaten Blora (Reni Wulansari, 2015)

Blora adalah sebuah kecamatan di Kabupaten Blora, Provinsi Jawa Tengah, Indonesia. Kecamatan Kota Blora ini berbatasan di sebelah utara dengan Kabupaten Rembang, di sebelah timur dan selatan dengan Kecamatan Jepon, di sebelah barat dengan Kecamatan Banjarejo dan Kecamatan Tunjungan. Blora juga merupakan ibu kota Kabupaten Blora.

Desa Kunden merupakan salah satu desa yang terdapat di Kecamatan Blora. Grup Kesenian Risang Guntur Seto terletak sekitar 500m dari pusat kota Kabupaten Blora.

Adapun batas desa/kelurahan adalah sebagai berikut: sebelah utara berbatasan dengan Kelurahan Gempolrejo, sebelah selatan berbatasan dengan 
Kelurahan Jetis, sebelah barat berbatasan dengan Kelurahan Sonorejo, sebelah timur berbatasan dengan Kelurahan Tempelan.

Berikut ini adalah denah lokasi dari grup kesenian barongan Blora Risang Guntur Seto:

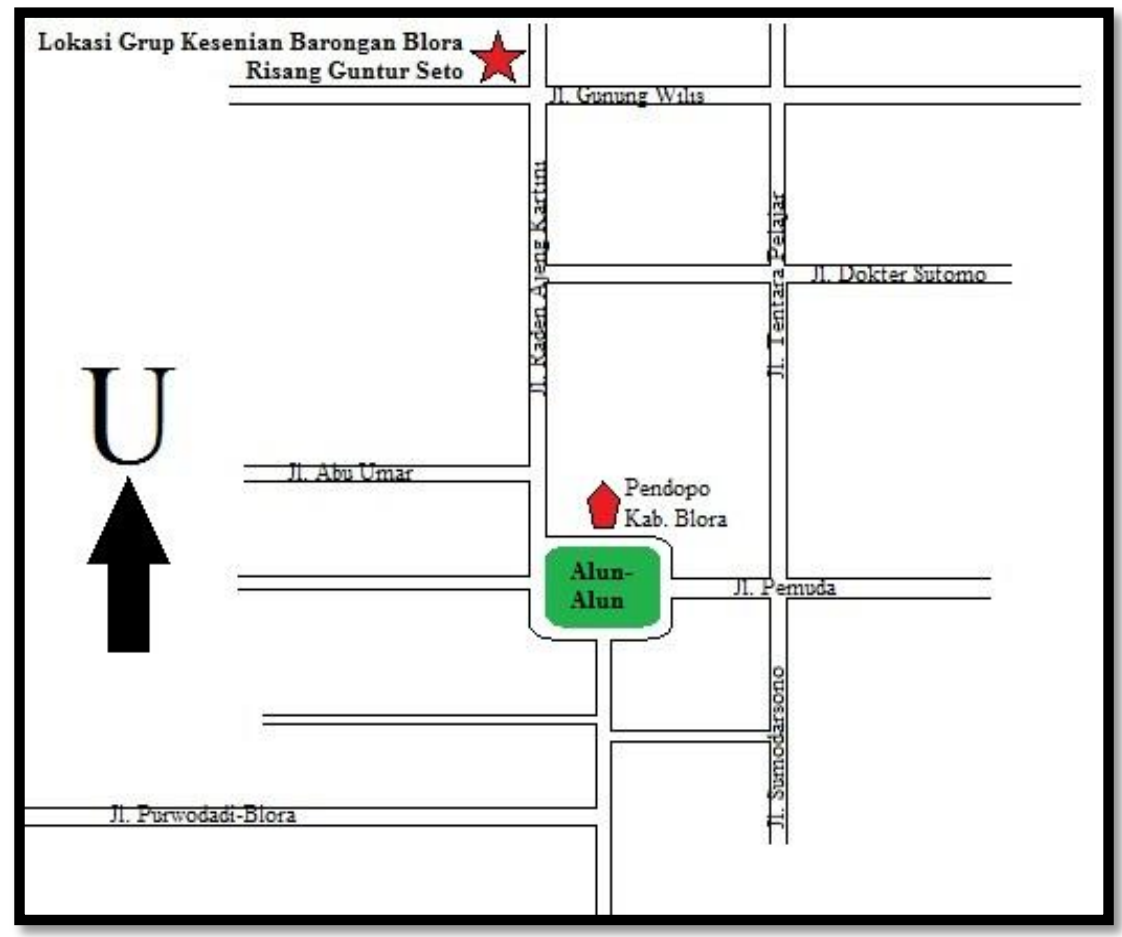

Gambar 4.2 Denah Lokasi Grup Kesenian Barongan Risang Guntur Seto (Sumber: Reni Wulansari, Juni 2015)

Lokasi Grup Kesenian Barongan Blora Risang Guntur Seto adalah merupakan rumah biasa seperti pada umunya. Alat-alat gamelan dan pranti barongan disimpan dalam gudang, dan latihan biasanya diadakan di halaman depan rumah. 
Berikut ini adalah gambar lokasi grup kesenian barongan Blora Risang Guntur Seto:

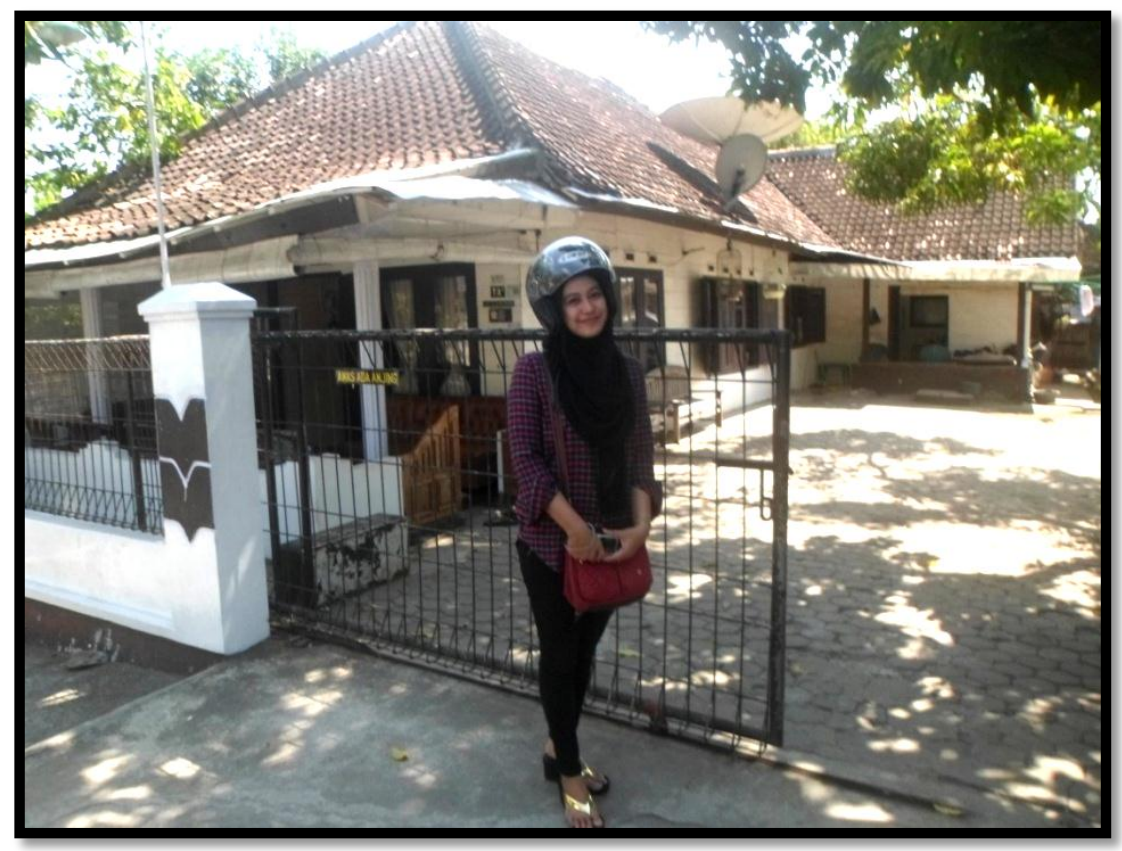

Gambar 4.3 Bagian Luar Lokasi Grup Risang Guntur Seto (Foto Reni Wulansari, 17 Mei 2015)

\subsection{Sejarah Grup Kesenian Barongan Blora Risang Guntur Seto}

Pada tahun 1999, Pak Adi Wibowo atau biasa dikenal dengan panggilan Pak Didik berbincang-bincang dengan Pak Ugi yang pada saat itu sedang berada di Ponorogo mengenai keinginannya untuk mengembangkan barongan Blora sehingga dikenal dengan masyarakat umum dan menjadi kesenian Blora, seperti macamnya Reog Ponorogo. Pada saat itu barongan Blora hanya merupakan barongan desa. Kemudian pada tanggal 20 Mei 1999 didirikanlah Grup Kesenian Barongan Blora Risang Guntur Seto oleh Pak Didik selaku ketua. Beliau menceritakan riwayat berdirinya grup Risang Guntur Seto: 
"Saya ketika mendirikan grup ini tanggal 20 Mei 1999, bulannya Suro dan malam Jumat Legi, h-2 sebelum barongan tak gebyakke, waktu itu saya sedang mandi tiba-tiba muncullah nama Risang Guntur Seto. Lalu setelah berfikir dan berfikir, saya artikan bahwa Risang Guntur Seto adalah niat kumoro yang resik." (wawancara dengan Pak Didik 19 Mei 2015)

Kemudian berdirilah grup kesenian barongan Blora Risang Guntur Seto seperti yang kita kenal sampai saat ini. Grup ini selain tampil di acara khitanan, ulang tahun, pernikahan, syukuran, dll, grup ini juga sering mewakili Kabupaten Blora dalam acara festival kesenian tradisional, festival Barongan Nasional, dll. Jadi sudah tidak diragukan lagi kualitas penampilannya dari segi musik maupun tariannya.

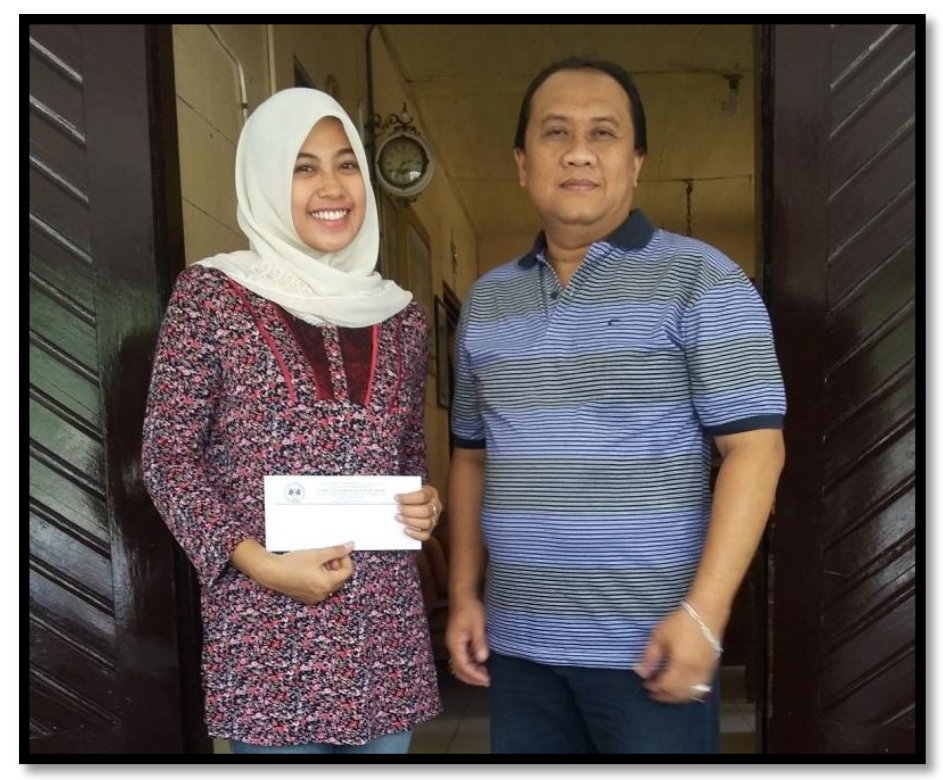

Gambar 4.4 Foto Peneliti dengan Ketua Grup Risang Guntur Seto (Dok. Reni, Oktober 2015) 


\subsection{Susunan Pengurus Grup Kesenian Barongan Risang Guntur Seto}

$\begin{array}{ll}\text { Ketua } & : \text { Adi Wibowo } \\ \text { Wakil Ketua } & : \text { Suprapto } \\ \text { Sekertaris } & : \text { Imam Ponco Santoso } \\ \text { Wakil Sekertaris } & : \text { Eko Purnomo } \\ \text { Bendahara } & : \text { Sugiharto } \\ \text { Wakil Bendahara } & : \text { 1. Supardi } \\ \text { Seksi Perlengkapan } & \text { 2. Jani Sumaryono } \\ \text { Penata Gerak dan Gendhing } & : \text { 1. Wiji Suharto } \\ & \text { 2. Edy Prabowo } \\ \text { 3. Budiyono } \\ \text { Transportasi }\end{array}$

\subsection{Penyajian Kesenian Barongan Grup Risang Guntur Seto}

Musik pendukung sangat berperan penting dalam suatu pertunjukkan kesenian, begitu pula dalam pertunjukan kesenian barongan Risang Guntur Seto. Seperti yang disampaikan oleh Pak Didik (19 Mei 2015), roh dari pertunjukan barongan terdapat pada gamelannya, musik iringannya. Alat musik yang digunakan pada awalnya hanya bonang, kempul, dan kendhang. Lalu ditambah lagi ada kedhuk, gong suwuk, saron, demung, jedor/drum, dan terompet. 


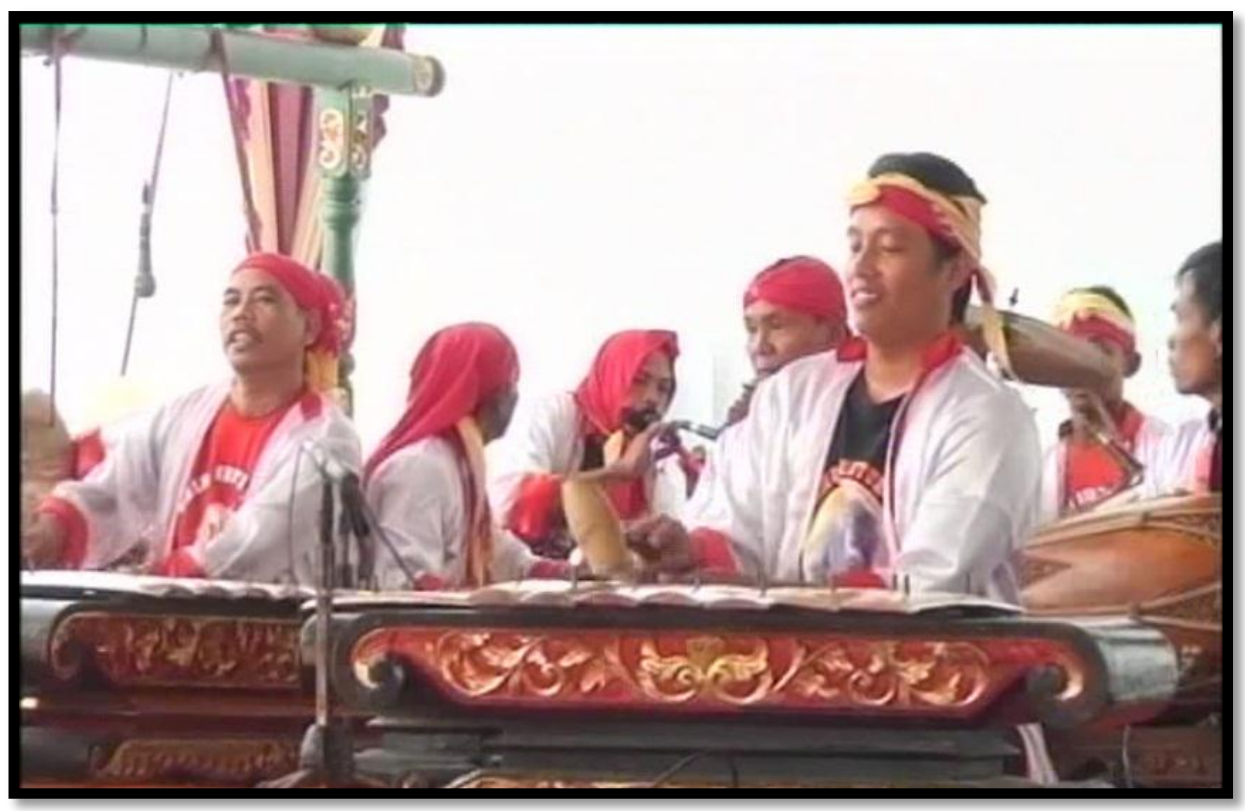

Gambar 4.5 Alat Musik Pendukung Barongan Risang Guntur Seto (Dok. Reni, April 2015)

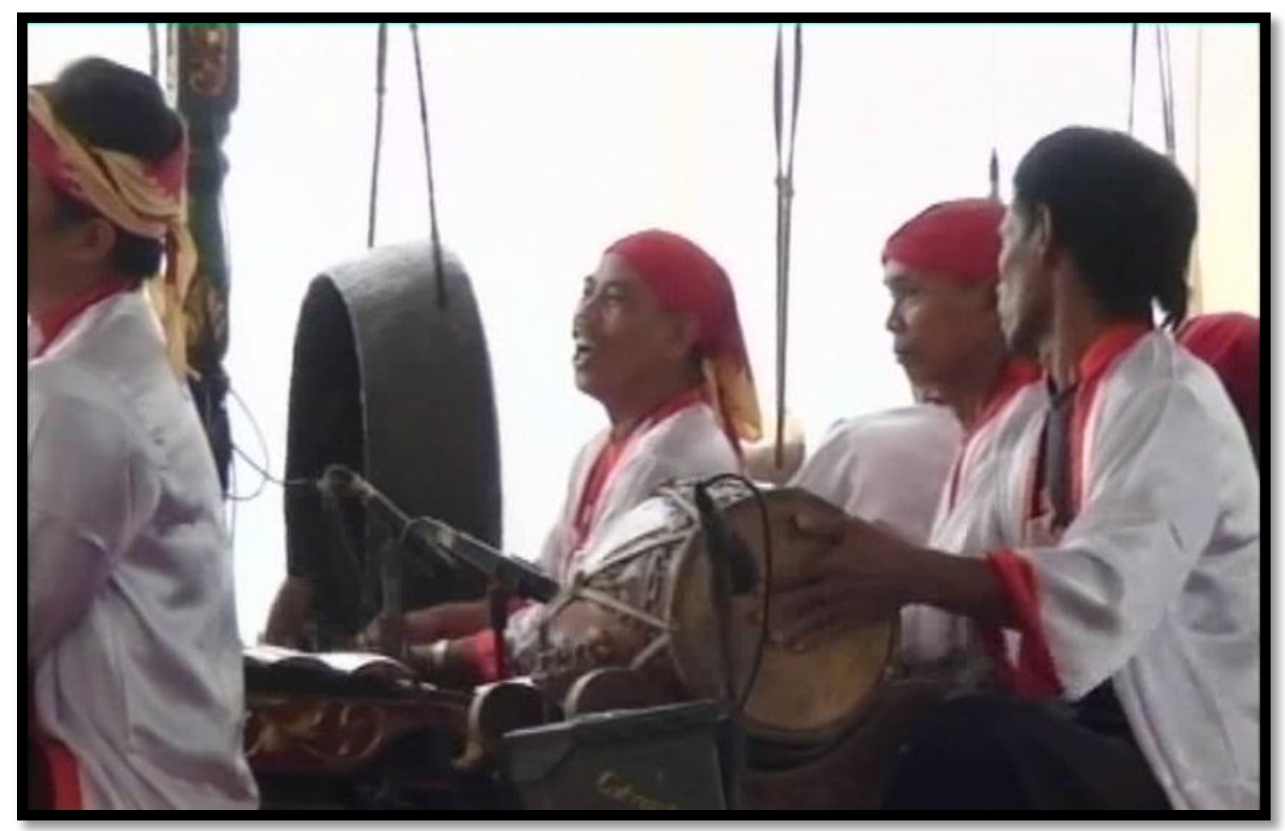

Gambar 4.6 Alat Musik Pendukung Barongan Risang Guntur Seto (Dok. Reni, April 2015) 
Peneliti mengambil sampel dari pertunjukan kesenian barongan Blora Risang Guntur Seto pada tanggal 11 April 2015, di acara khitanan putra dari Bapak Sigid Ariyanto di Rembang Jawa tengah. Pada pertunjukan itu, peneliti menyaksikan langsung di lokasi, sehingga memudahkan langsung untuk meneliti komposisi musik iringannya.

Iringan musik kesenian barongan Risang Guntur Seto menggunakan aransemen musik jawa mulai dari tembang macapat sampai lagu-lagu jawa populer masa kini sebagai hiburan di sela-sela pertunjukan. Musik iringan kesenian barongan Risang Guntur Seto menggunakan gamelan jawa berlaras pelog dan slendro, namun sebagian besar menggunakan laras slendro.

\subsubsection{Persiapan Pemain}

Sebelum pertunjukan dimulai, pemain melakukan persiapan mulai dari pengecekan panggung, alat musik, sound system, kostum dan tata rias. Busana atau kostum dan rias akan menunjukkan watak karakter peran yang dibawakan, selain itu merupakan aspek pendukung artistik dan estetik penyajian seni. Dalam penyajian barongan secara lengkap biasanya pengrawit menggunakan busana seragam, demikian juga pawang memakai busana tersendiri untuk membedakannya.

Pada seni barongan busana sangat memengaruhi karakter dari tokoh-tokoh yang ada di dalamnya. Namun demikian, busana yang ada dalam seni barong antara organisasi satu dengan lainnya memiliki corak yang berbeda, namun tidak 
menutup kemungkinan untuk dikembangkan lebih lanjut, sehingga memiliki ciri khas tersendiri.

Peneliti sempat masuk ke dalam ruang dimana para pemain melakukan persiapan kostum dan tata rias. Sebagian besar para pemain musik dan penari lakilaki, melakukan persiapan sendiri, karena kostum dan riasnya yang cukup sederhana. Pemain musik hanya menggunakan kaos seragam, celana panjang komprang berwarna hitam, rompi berwarna putih, dan ikat kepala modangan.

Berikut ini adalah contoh pemakaian kostum penabuh gamelan:

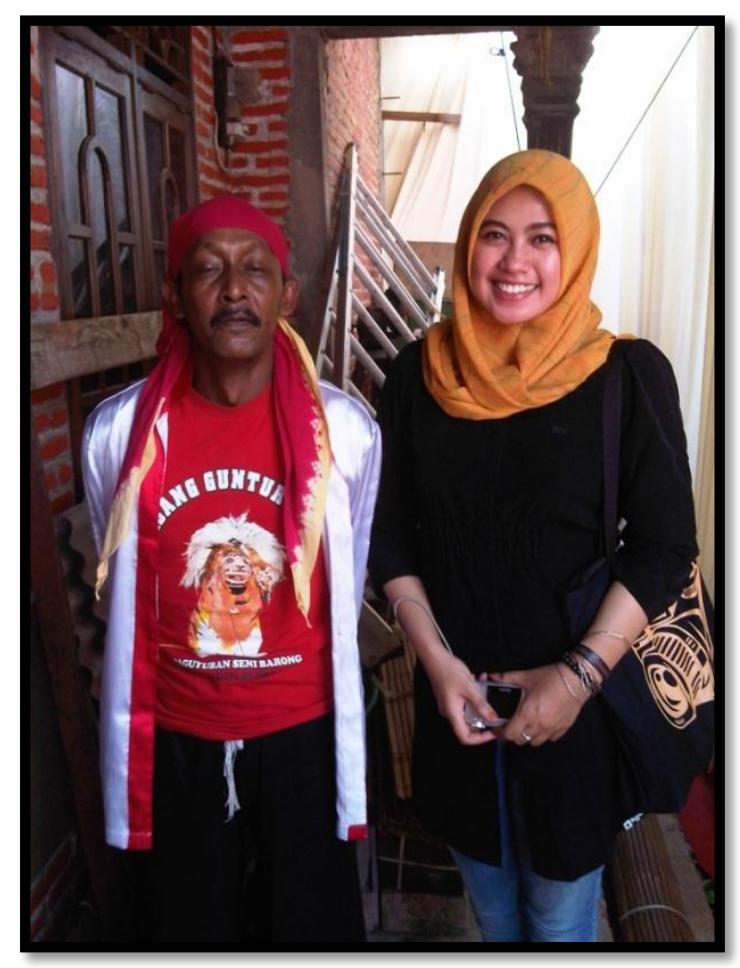

Gambar 4.7 Kostum Pengrawit Grup Risang Guntur Seto (Dok. Reni, April 2015)

Kostum yang dipakai oleh penari jaranan adalah ikat kepala/ jamang, sumping, kelat bahu, kalung kace, baju merah tanpa lengan, sabuk kamus timang, 
kain/ nyamping bermotif parang, benggel, sampur/ sonder. Sedangkan tata rias yang dipakai merupakan tata rias tari pada umumnya.

Berikut ini adalah contoh pemakaian kostum penari jaranan:

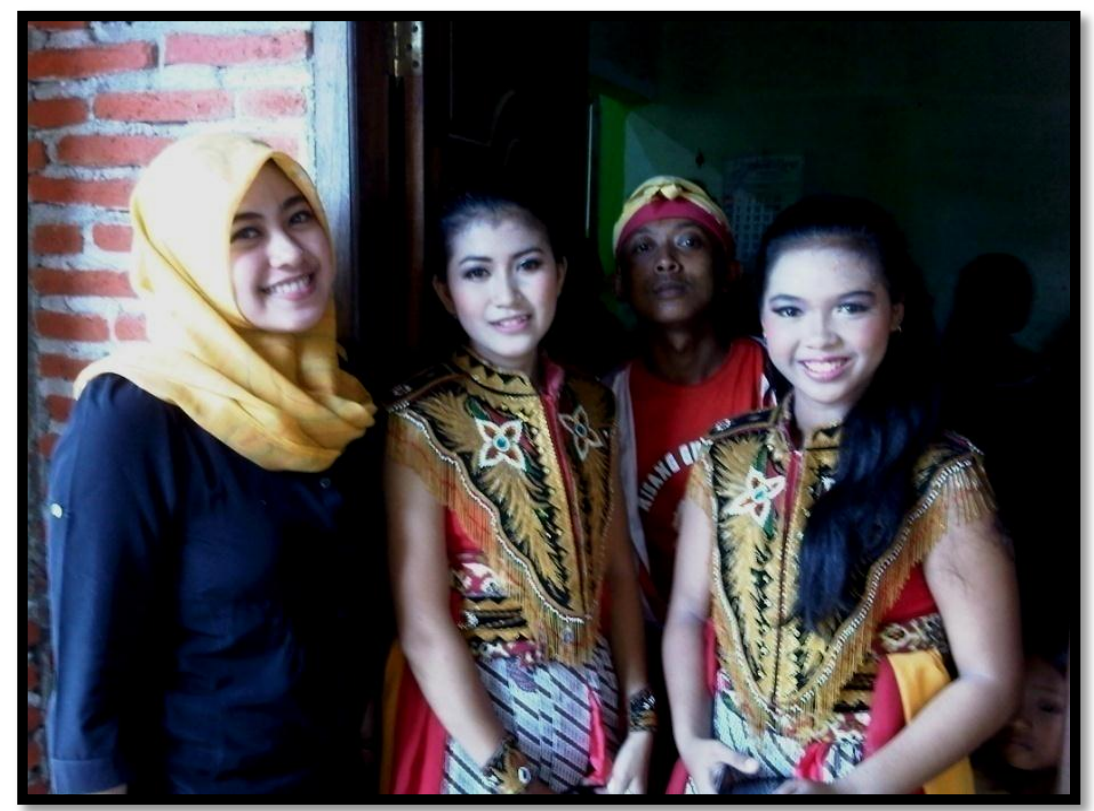

Gambar 4.8 Kostum Penari Jaranan Grup Risang Guntur Seto (Dok. Reni, April 2015)

Kostum dan tata rias yang dipakai oleh penari topeng seperti bujangganong, untub, nayantaka adalah celana sebatas lutut, rompi, ikat kepala dan topeng sesuai karakter masing-masing. Sedangkan kostum dan tata rias yang dipakai oleh penari barongan adalah celana sebatas lutut, kaos, dan barongan. Kostum yang dipakai sinden adalah kebaya dan jarik dengan riasan penyanyi seperti pada umumnya dan bersanggul. 


\subsubsection{Urutan Penyajian Karawitan Pendukung Kesenian Barongan Risang Guntur Seto}

Berikut urutan penyajian musik pendukung/ musik iringan grup kesenian barongan Blora Risang Guntur Seto. Sebagai musik pembuka, diawali dengan iringan barongan (bonang mo-nem slendro) dan diikuti oleh instrumen lain. Kendhang sebagai instrumen penentu tempo dan dinamika iringan. Diselingi dengan alok 'hak e hokya' oleh penggerong dan sinden. Alok yang dibunyikan umunya tidak beraturan atau tidak memiliki pola tertentu, sehingga penggerong dan sinden bersahut-sahutan menghidupkan suasana secara spontan. Alok yang dibunyikan dapat berupa 'e e e hokya', 'hak e hokya hak e hokya', 'lololololo', 'yaaaaaaa', dan sebagainya. Pada bagian ini, musik digunakan untuk mengiringi penari masuk ke area panggung, dan untuk menggugah semangat penonton. Kemudian dilanjutkan dengan gendhing-gendhing tayub berlaras slendro yang dinyanyikan oleh sinden. Gendhing-gendhing tayub sering dibawakan karena mencerminkan ciri khas kesenian tradisional kabupaten Blora. Berikut pola iringan Barongan bonang mo-nem laras slendro:

$\begin{array}{llllllll}\wedge & \hat{5} & \wedge & \hat{1} & \wedge & \hat{1} & \wedge & \hat{6}\end{array}$

Menurut cerita dari Pak Sigid, salah satu penata musik barongan Risang Guntur Seto, pola iringan bonang mo-nem memiliki sejarah untuk trans pemanggil roh agar masuk dan ketika fokus memainkan bonang mo-nem dapat memudahkan dalam konsentrasi untuk mengundang roh dimensi lain. 


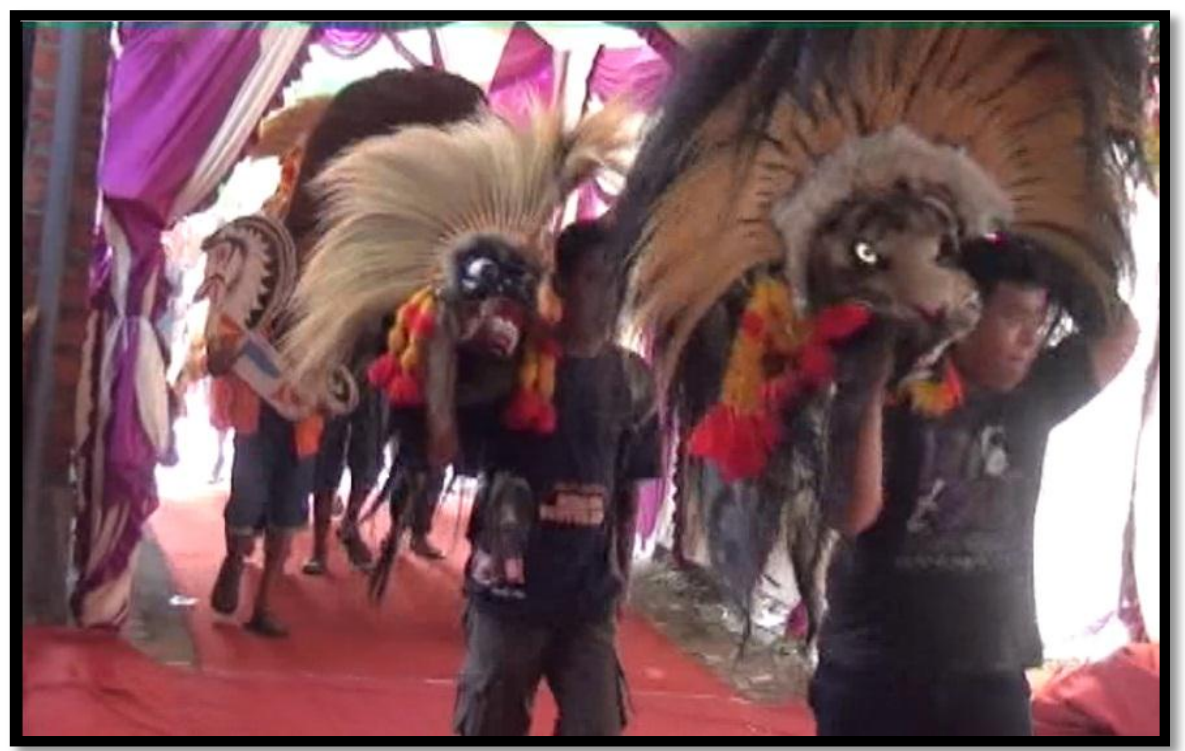

Gambar 4.9 Penari Masuk ke Area Panggung

(Dok. Reni, April 2015)

Setelah semua pemusik dan penari siap di area panggung, pertunjukan pun dimulai. Sebagai lagu pembuka, sinden menyanyikan lagu Guntur Seto, yang intinya berisi tentang grup kesenian barongan Blora Risang Guntur Seto itu sendiri. Berikut titi laras dan cakepan lancaran pambuka Guntur Seto laras pelog pathet 5:

Buka: Balungan

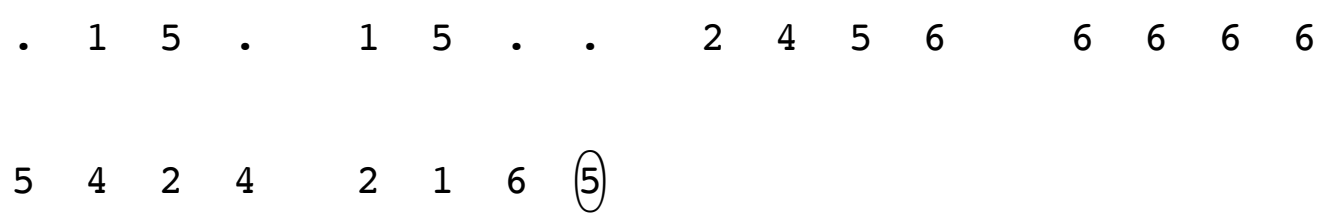

Umpak (balungan mlaku):

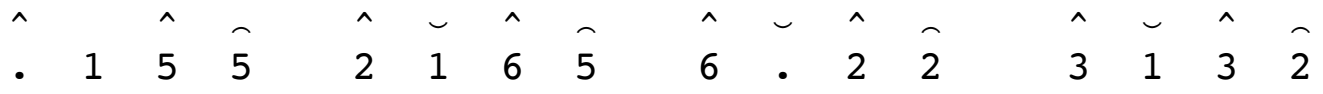




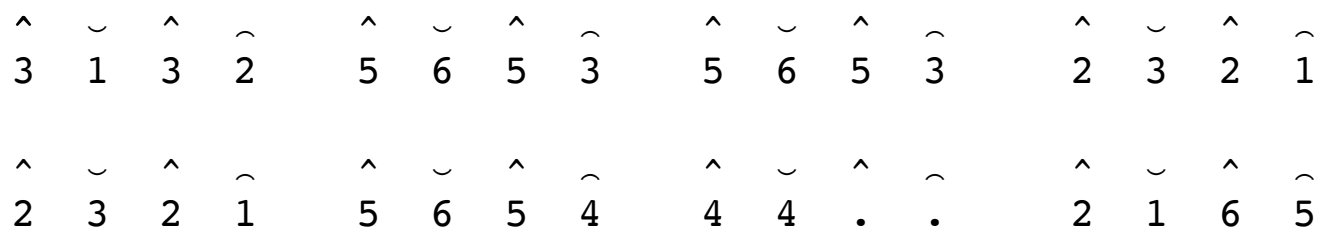

Lagu (balungan nibani):

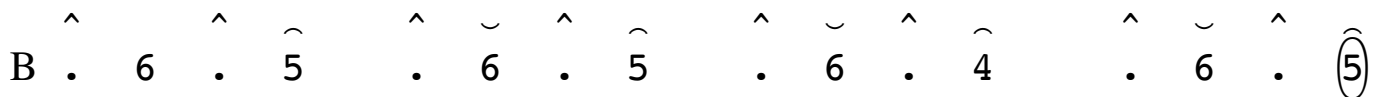

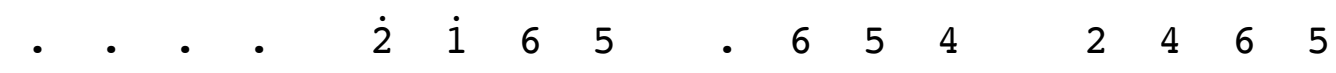

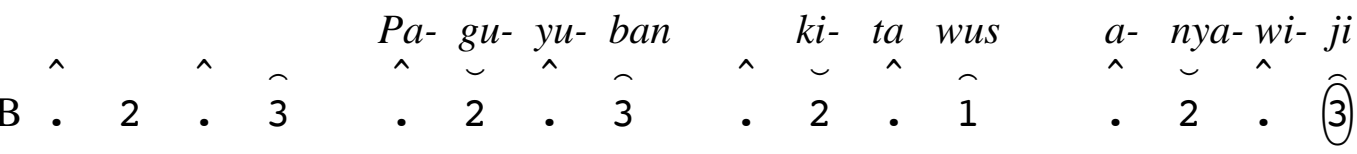

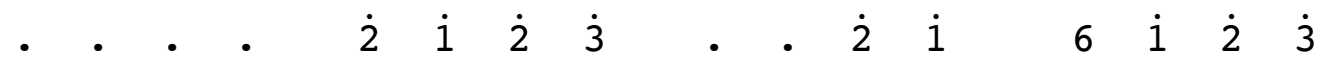
Mbu-di-da- ya ke-se- ni- an ki- ta

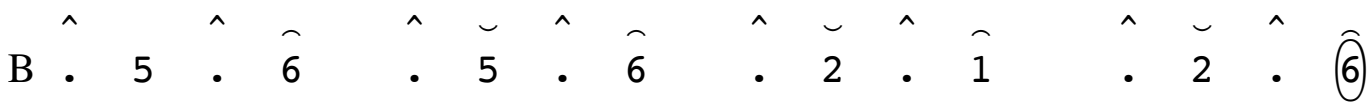

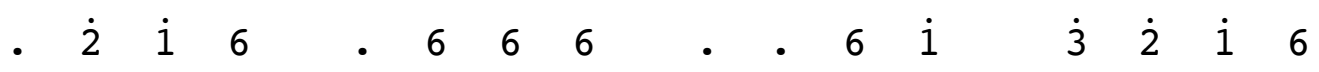
Pam-rih-e su-pa- ya tan-sah ang-rem-ba-ka

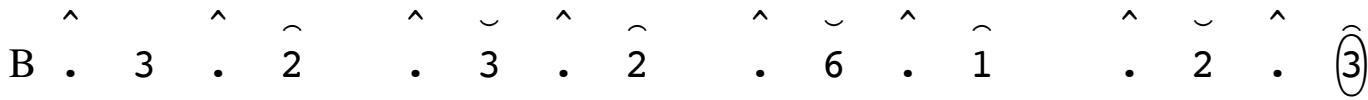

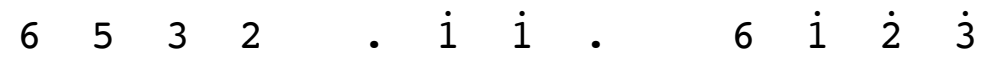
Se- ni ba-rong Ri-sang Gun-tur Se-to

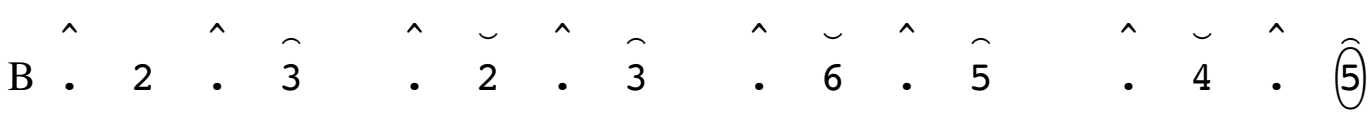

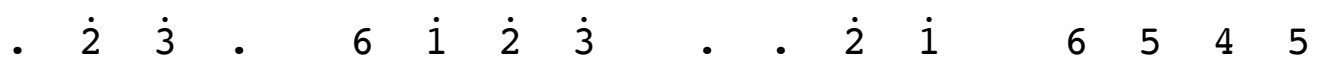
Si- grak pe-na-buh-e ram-pak pe-na-ri-ne 


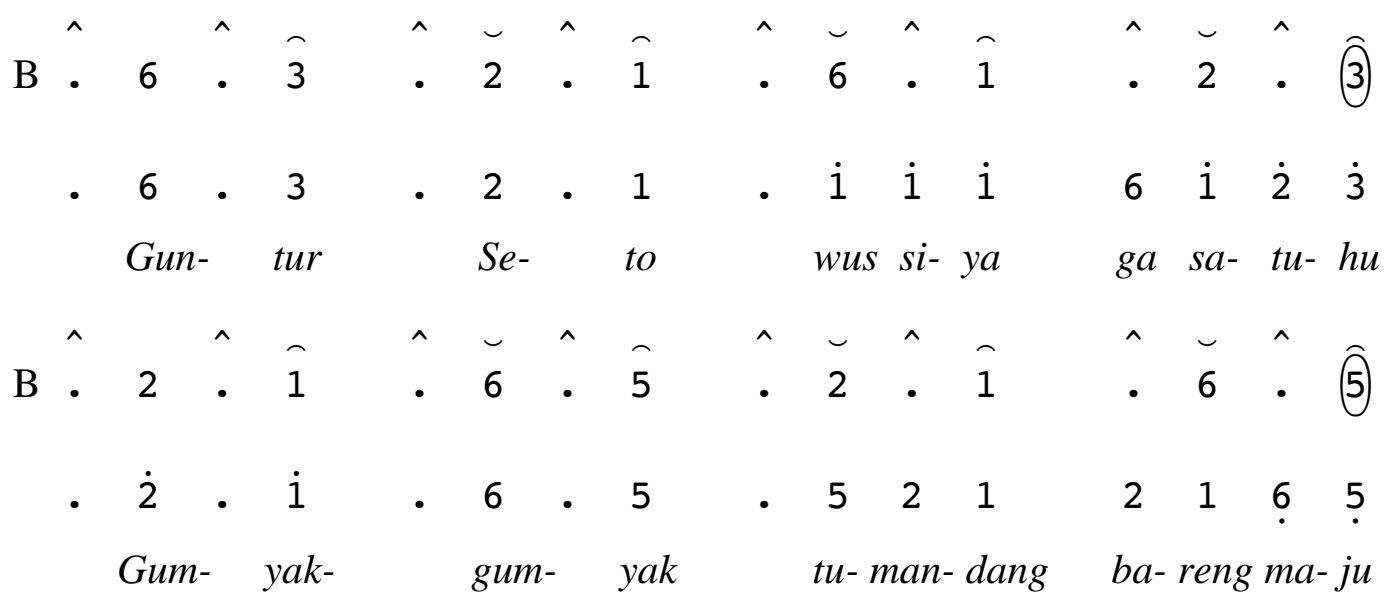

Keterangan:

Balungan Mlaku $\quad$ : Balungan dipukul di tiap ketuk

Balungan Nibani $\quad$ : Balungan dipukul hanya pada hitungan genap

Gendhing ini bisa dikatakan gendhing lancaran karena dilihat dari susunan balungannya dimana dalam satu gongan terdapat 4 gatral 16 ketukan. Kethuk ditabuh pada nada hitungan ganjil, yaitu pada hitungan ke 1,3,5,7,9,11,13,15 dalam satu gatra. Kenong ditabuh disetiap akhir gatra/ 4 ketuk sekali. Dan kempul ditabuh pada nada genap setelah gatra pertama, yaitu pada hitungan ke $6,8,10,12,14$, dan 16 bersamaan dengan gong.

Setelah lancaran pambuka Guntur Seto dinyanyikan, Pak Didik selaku ketua grup (pawang) kesenian barongan Blora Risang Guntur Seto masuk ke area panggung, dengan posisi memeluk barongan satu per satu seperti memunculkan aura mistis, dan diiringi dengan macapat Asmarandhana laras slendro pathet sanga (miring) sebagai berikut: 
Pola Gangsaran:

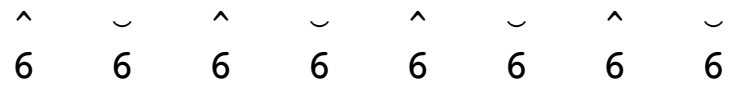

Intro:

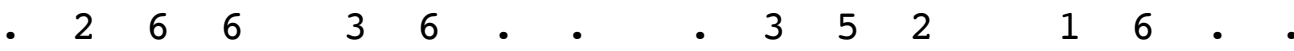

• $\quad \begin{array}{lllllll} & 5 & 6 & \mathrm{i} & \cdot & & \end{array}$

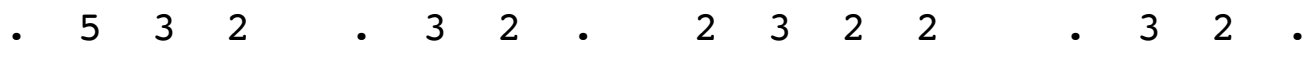

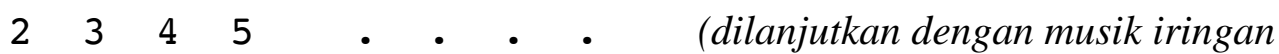
barongan seperti pola pada halaman sebelumnya)

Lagu:

$\begin{array}{llllllll}1 & 2 & 3 & 5 & 5 & 5 & 5 & 5\end{array}$

A- mur- wa- ni a- mi- wi- $t i$

$\begin{array}{llllllllll}5 & i & \dot{2} & \dot{3} & i & i & 5 & 5\end{array}$

$\mathrm{Pi}^{-}$ne- thik ca- ri- ta- ni- $\mathrm{ra}$

$\begin{array}{lllllllll}3 & 2 & 1 & 5 & z & 2 & z & 1 & 2\end{array}$

Kya- $i \quad$ gem-bong a- mi- ja- ya

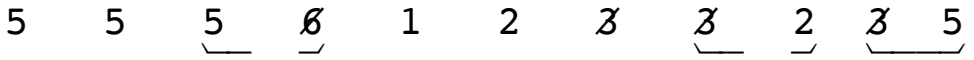

A- las weng- ker kang ri- nek- sa

$\begin{array}{llllllll}3 & 2 & 2 & 2 & 2 & 3 & 2 & 1\end{array}$

Ri- na- kit da- dya bu- da- ya 


$\begin{array}{lcccccccc}5 & 1 & 2 & 2 & 2 & \underbrace{3} & 5 & \underbrace{3} \\ \text { Se- } & n i & b a- & \text { ro- } & \text { ngan } & \text { tu- } & h u \\ 6 & 6 & 6 & 6 & 1 & 2 & z & \underbrace{2} & 1 \\ \text { Kun- ca- } & \text { ra } & \text { ba- } & \text { ro- } & \text { ngan } & \text { Blo- } & \text { ra }\end{array}$

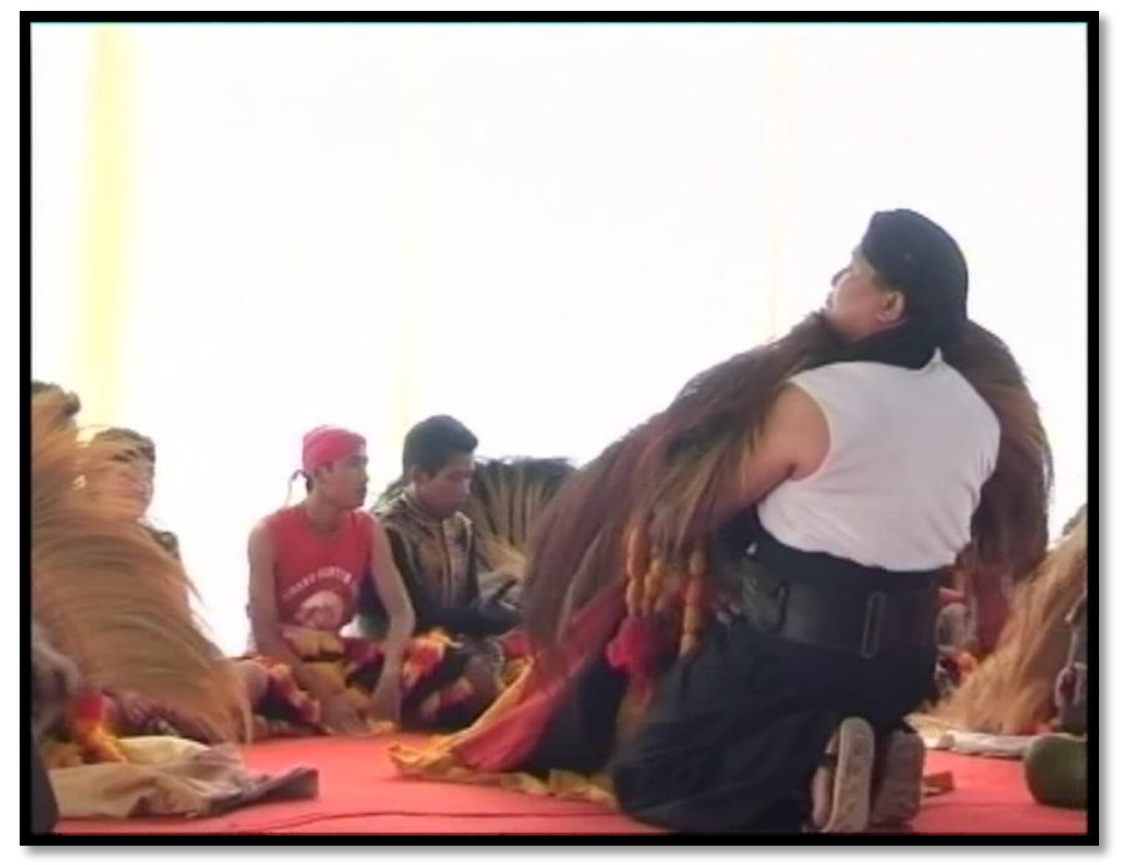

Gambar 4.10 Pawang dan Barongannya

(Dok. Reni, April 2015)

Macapat tersebut bisa dikatakan macapat Asmarandhana karena memiliki guru gatra yang dilihat dari jumlah baris dalam 1 bait ada 7 baris. Kemudian macapat tersebut memiliki guru lagu i,a,e,a,a,u,a. Namun dalam macapat Asmarandhana di atas terdapat sedikit perbedaan pada guru lagu yaitu i,a,a,a,a,u,a.

Selanjutnya sinden menyanyikan lancaran Barongan Blora, yang menceritakan tentang asal usul barongan Blora itu sendiri. Berikut titi laras dan cakepan lancaran Barongan Blora: 
Umpak:

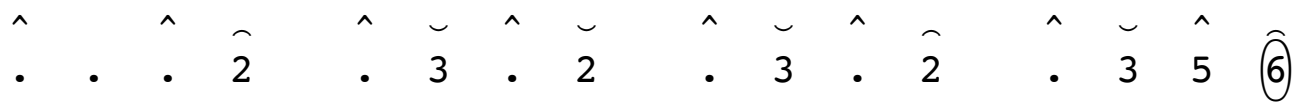

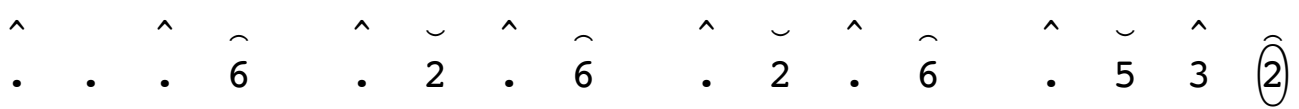

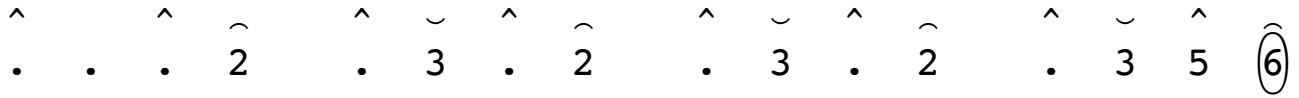

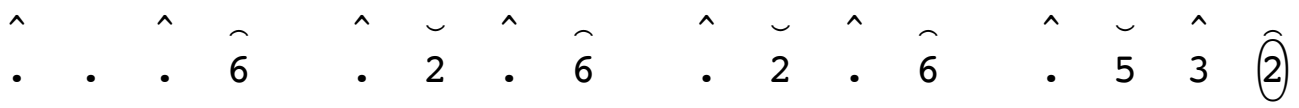

Lagu:

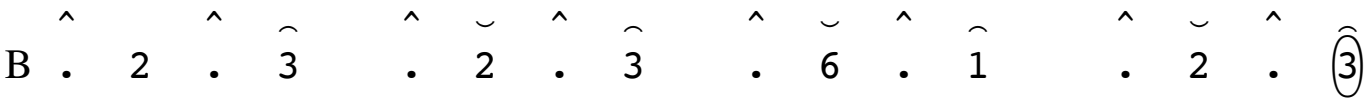

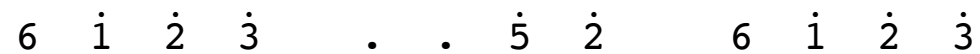

$$
\begin{aligned}
& \text { Si- nu- ra-sa ang-ge- lar bu-da- ya }
\end{aligned}
$$

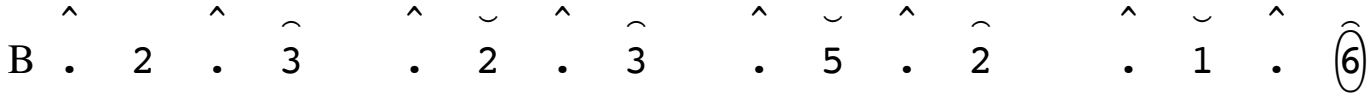

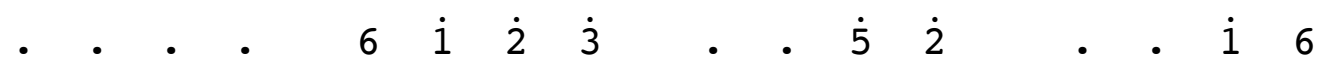

$$
\begin{aligned}
& \text { Se- ni ba-rong ki- tha Blo-ra }
\end{aligned}
$$

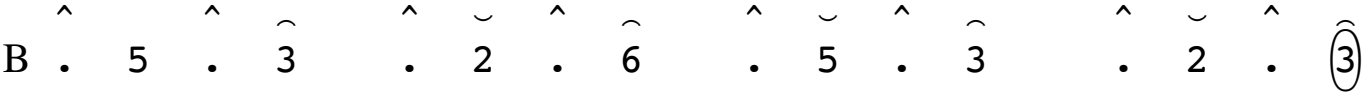

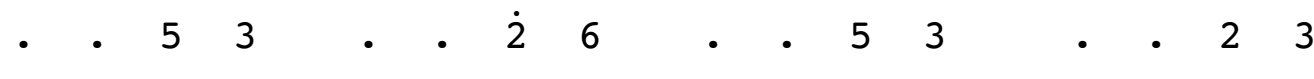

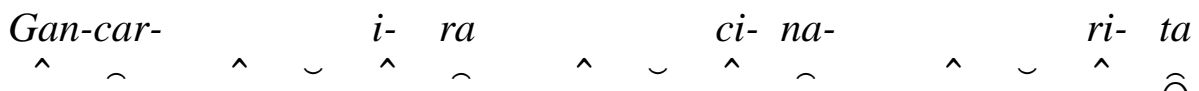

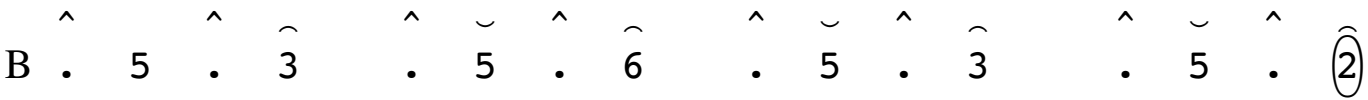

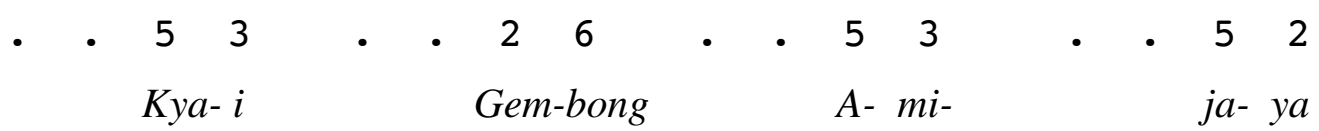




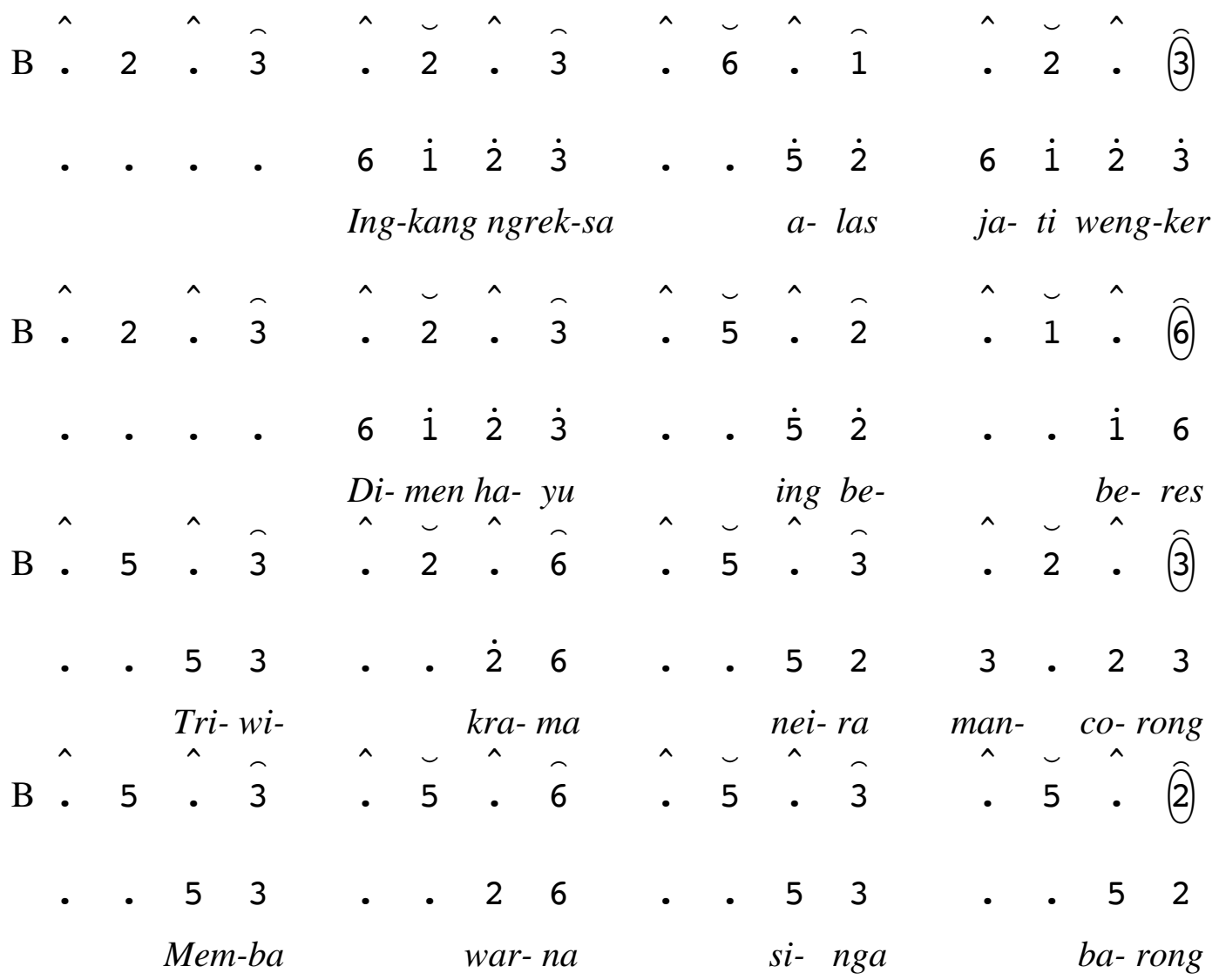

Kemudian disambung dengan lancaran bujangganong sebagai berikut:

Umpak:

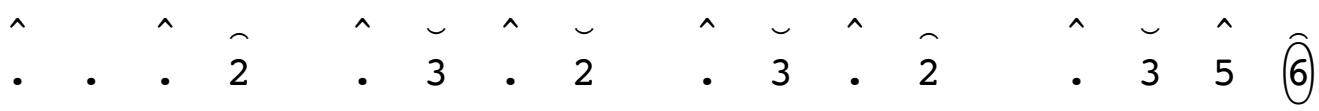

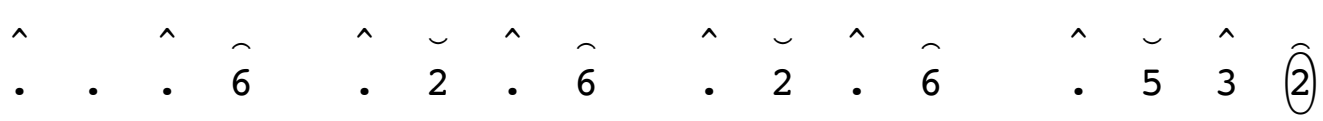

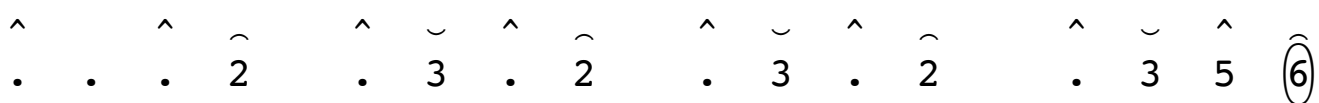

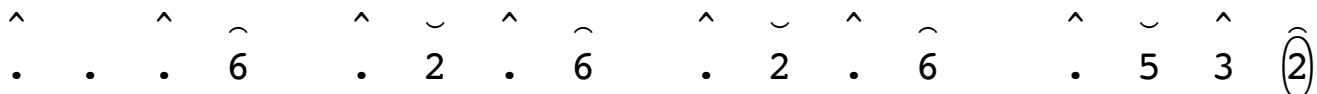


Bk. CELUK

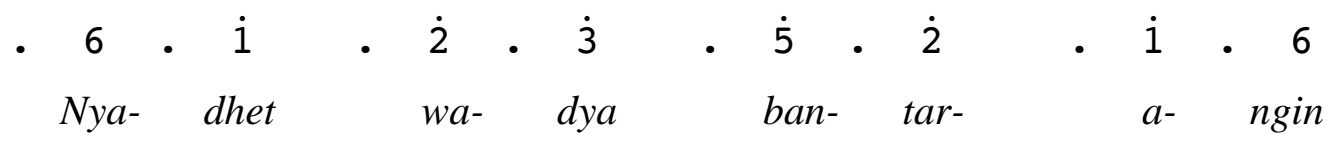

Rambatan:

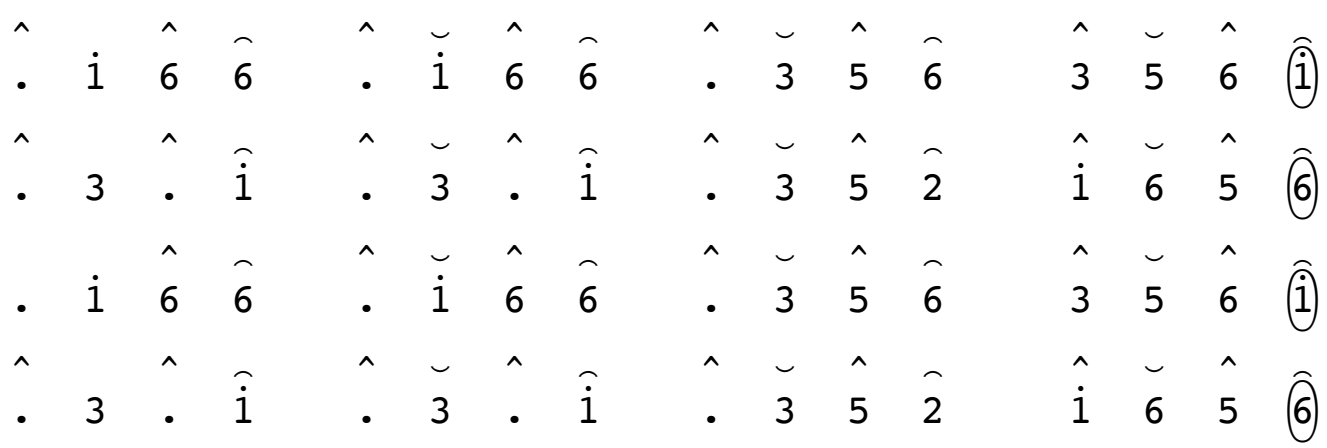

Lagu:

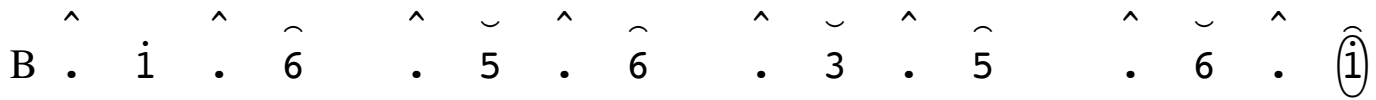

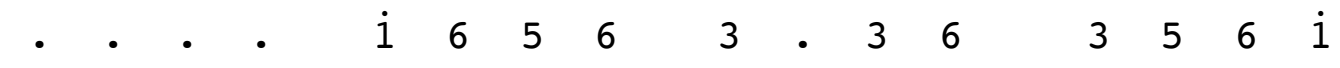

Ka-pan-dhe-gan sang pa-tih bu-jang-ga-nong Si-nga ba-rong ^ung-gul $\quad$ A $y u$ - $d a$

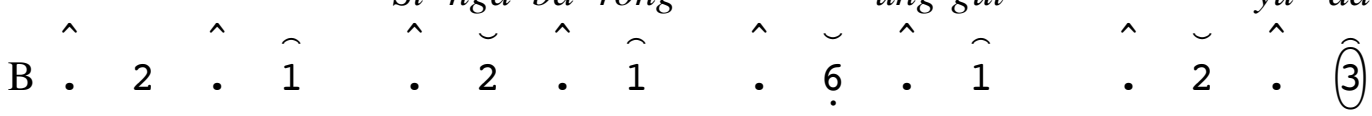

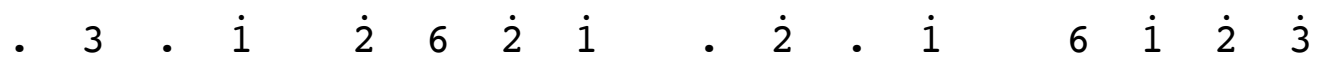

Wa- dya ni- tih ku-da won- ten ca-tur war-na Tan- $k a \quad$ nya- na prap- teng ja-ka lo-dra

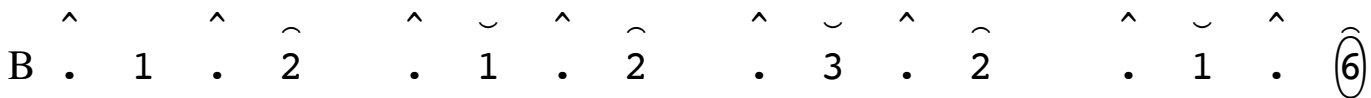

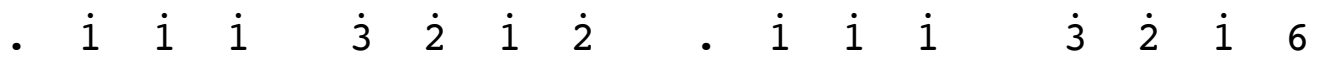

La-re-an lan pa-ne-gar pa-nyi- sih lan sang-sa-ngan Ka-wen-tar ing gen-dru-won kang da- dya se-sing-lon 


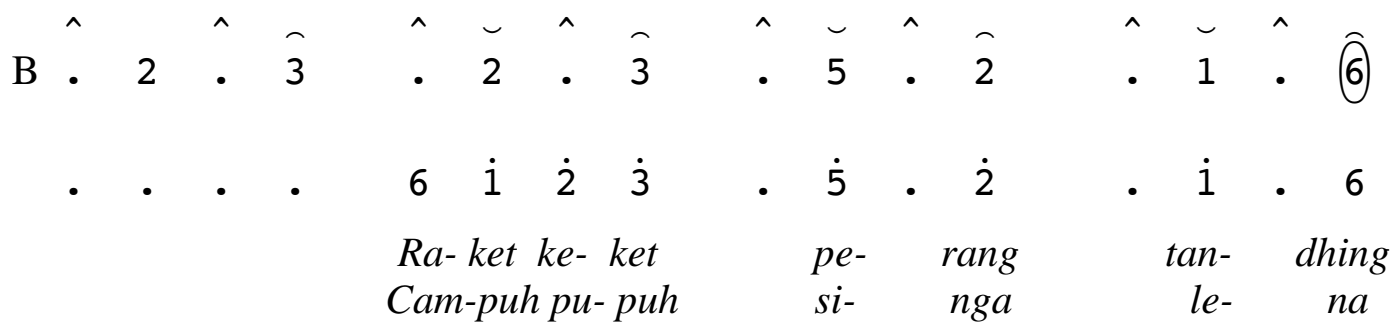

Setelah lancaran bujangganong selesai dinyanyikan, dilanjutkan dengan gendhing-gendhing wayang, sambil pawang masih terus melanjutkan ritualnya dengan barongan-barongan seolah-olah sedang ngudang barongan. Di depannya terdapat pecut besar milik pawang yang pangkalnya direndam dalam satu butir buah kelapa, yang kemudian nanti air kelapanya akan diminum sendiri oleh pawang, bergantian dengan pemain barongan.

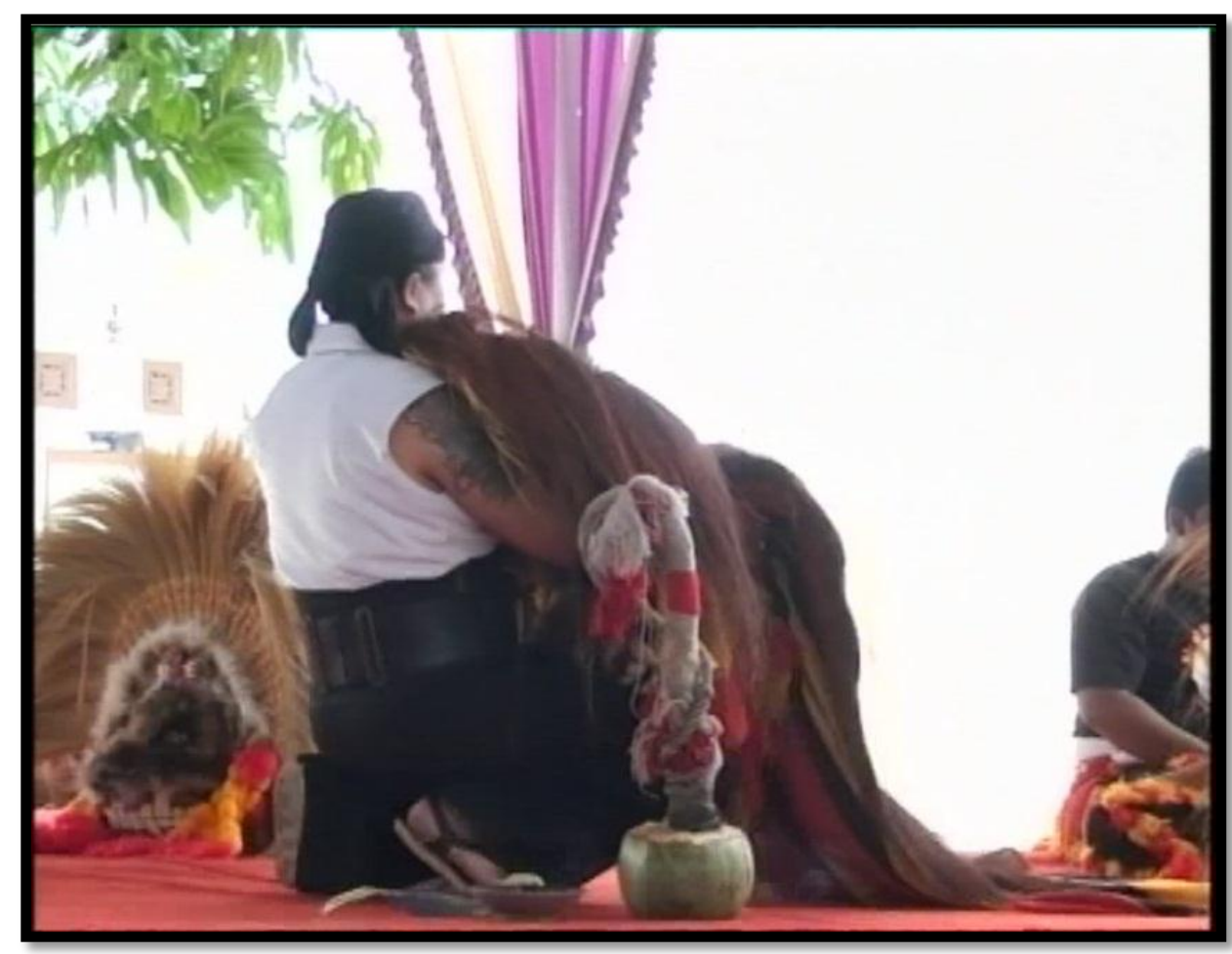

Gambar 4.11 Pawang Ngudang Barongan

(Dok. Reni, April 2015) 
Selanjutnya 3 orang penari barong mulai memasuki masing-masing barongan yang telah selesai diritualkan. Musik iringan barongan mulai dimainkan dan tetap diselingi dengan alok-alokan. Musik iringan barongan (bonang mo-nem) dalam bagian ini dimainkan dalam tempo yang cepat dan dinamika yang keras.

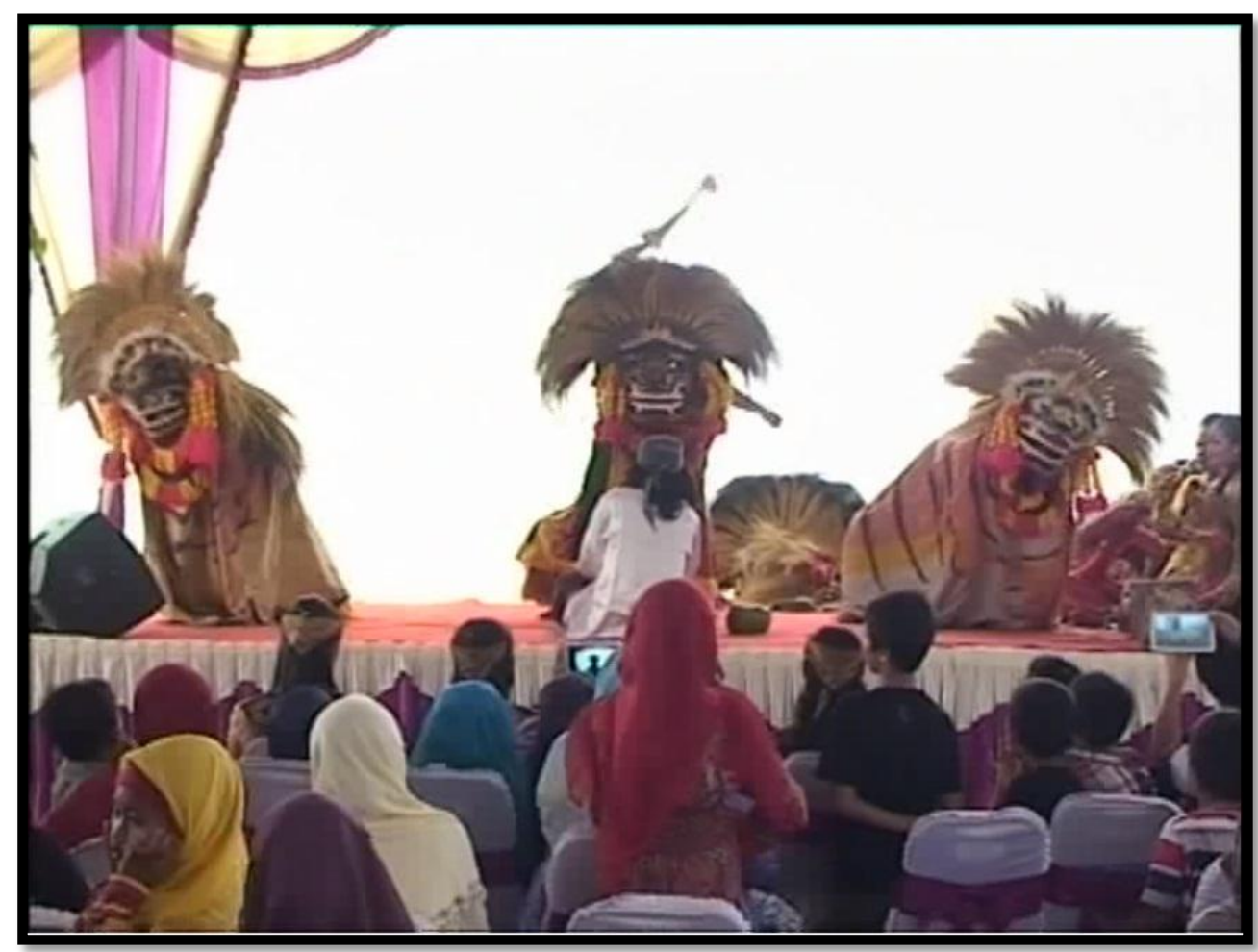

Gambar 4.12 Barongan Mulai Berdiri dan Menari

(Dok. Reni, April 2015) 
Kemudian penthul bujangganong mulai menguasai panggung dan menari. Pada bagian ini, instrumen gamelan yang paling membutuhkan keahlian khusus dan konsentrasi penuh adalah kendhang. Karena dalam hal ini, musik iringanlah yang mengikuti penari, bukan penari yang mengikuti musik. Seperti yang dikatakan Pak Didik dan Pak Ugi bahwa kendhang merupakan nafas, jiwa, dan rohnya suatu gamelan. Sehingga yang bisa mengangkat atau menghentikan penari dan pemusik itu sendiri adalah instrumen kendhang. Musik yang dimainkan hanya berupa musik iringan Barongan tanpa cakepan yang diisi dengan alok bersahutan antara penggerong dan sinden, terkesan ramai, rancak, dan semangat. Sesekali diisi dengan lagu-lagu anak populer seperti Pok Ame-ame.

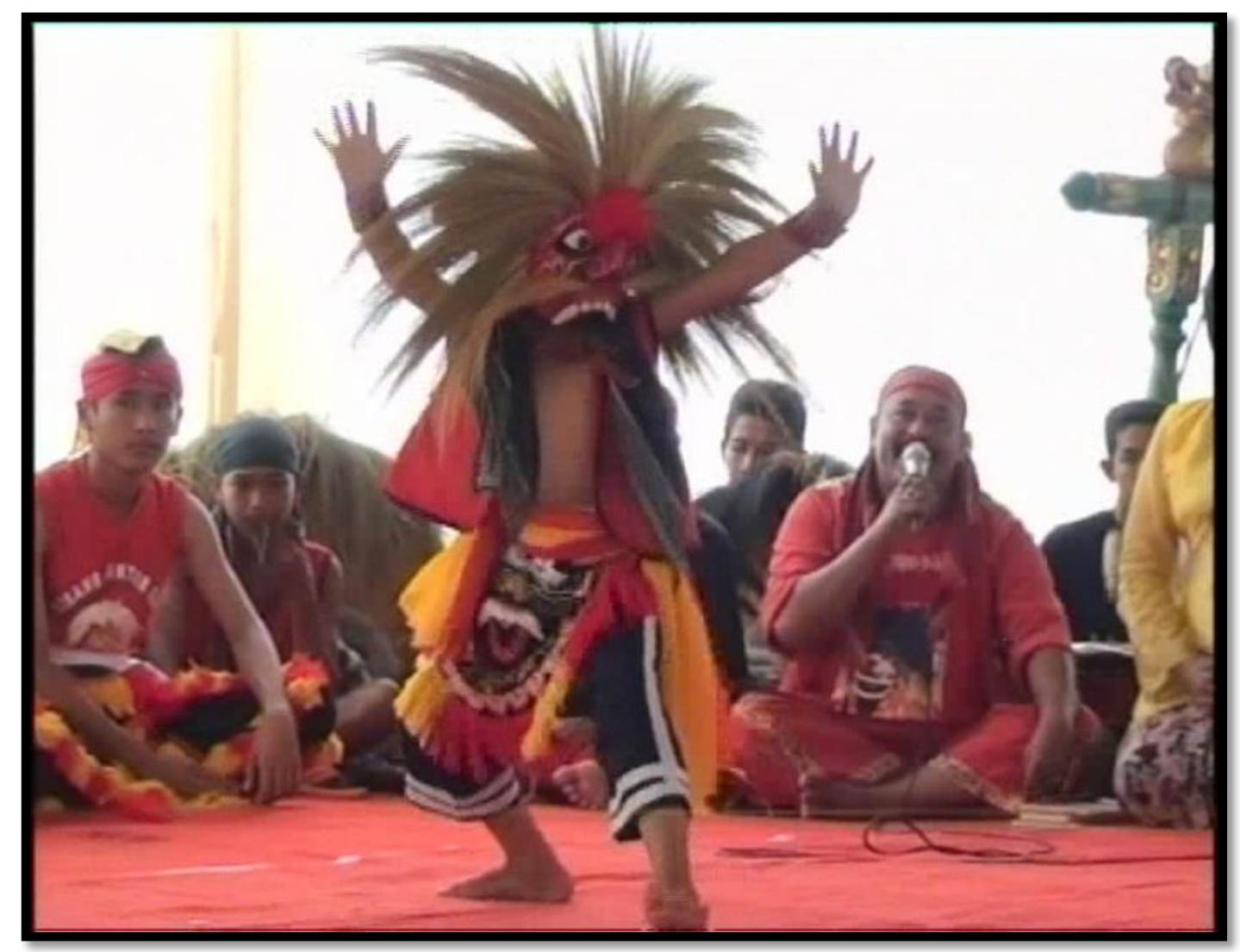

Gambar 4.13 Penthul Bujangganong

(Dok. Reni, April 2015) 
Setelah aksi dari bujangganong selesai, sebagai tambahan biasanya diselingi dengan lagu-lagu langgam atau campursari populer. Kemudian pasukan penari jaranan mulai naik ke area panggung, berbaris rapi. Lalu genderuwo datang, diiringi dengan musik bernuansa seram dan tegang. Bonang mo-nem selalu dibunyikan sepanjang pertunjukkan, kecuali pada saat break. Oleh karena itu, penabuh bonang mo-nem pun juga harus memiliki konsentrasi tinggi, karena bila konsentrasi buyar sedikit saja musik pun akan terdengar pincang. Pada bagian ini terjadi kolaborasi tarian nyandra antara penari jaranan dan genderuwo. Ketika penari jaranan menarikan tariannya, diiringi dengan musik tanpa cakepan dan sesekali diisi dengan gendhing-gendhing, tergantung suasanya tariannya.

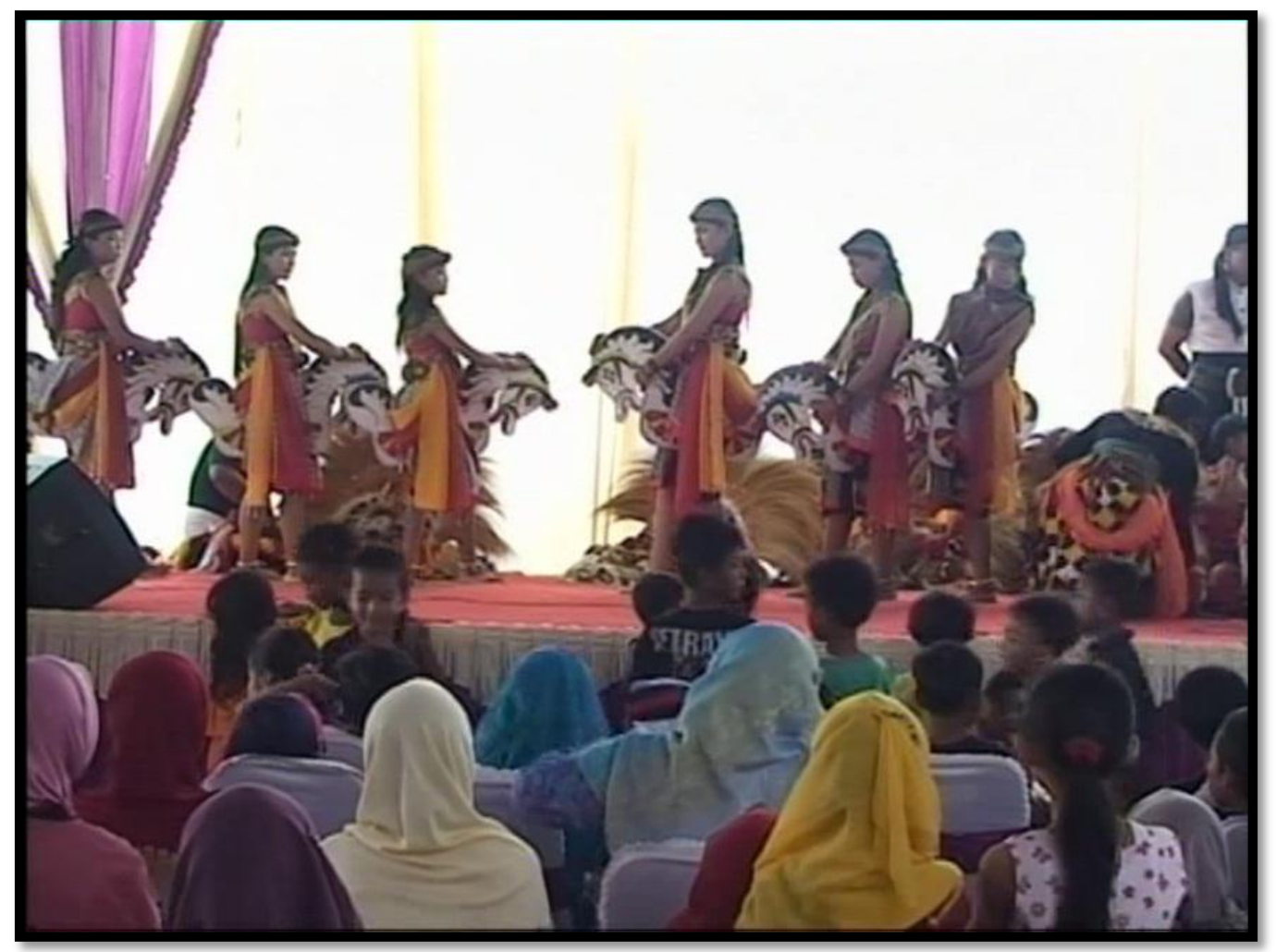

Gambar 4.14 Penari Jaranan

(Dok. Reni, April 2015) 
Pada bagian selanjutnya, muncullah Nggainah, penthul menyerupai wanita dengan bibir merot dan menggunakan daster, untup dan nayantaka (prajurit dari Raden Panji), sebagai lawakan.

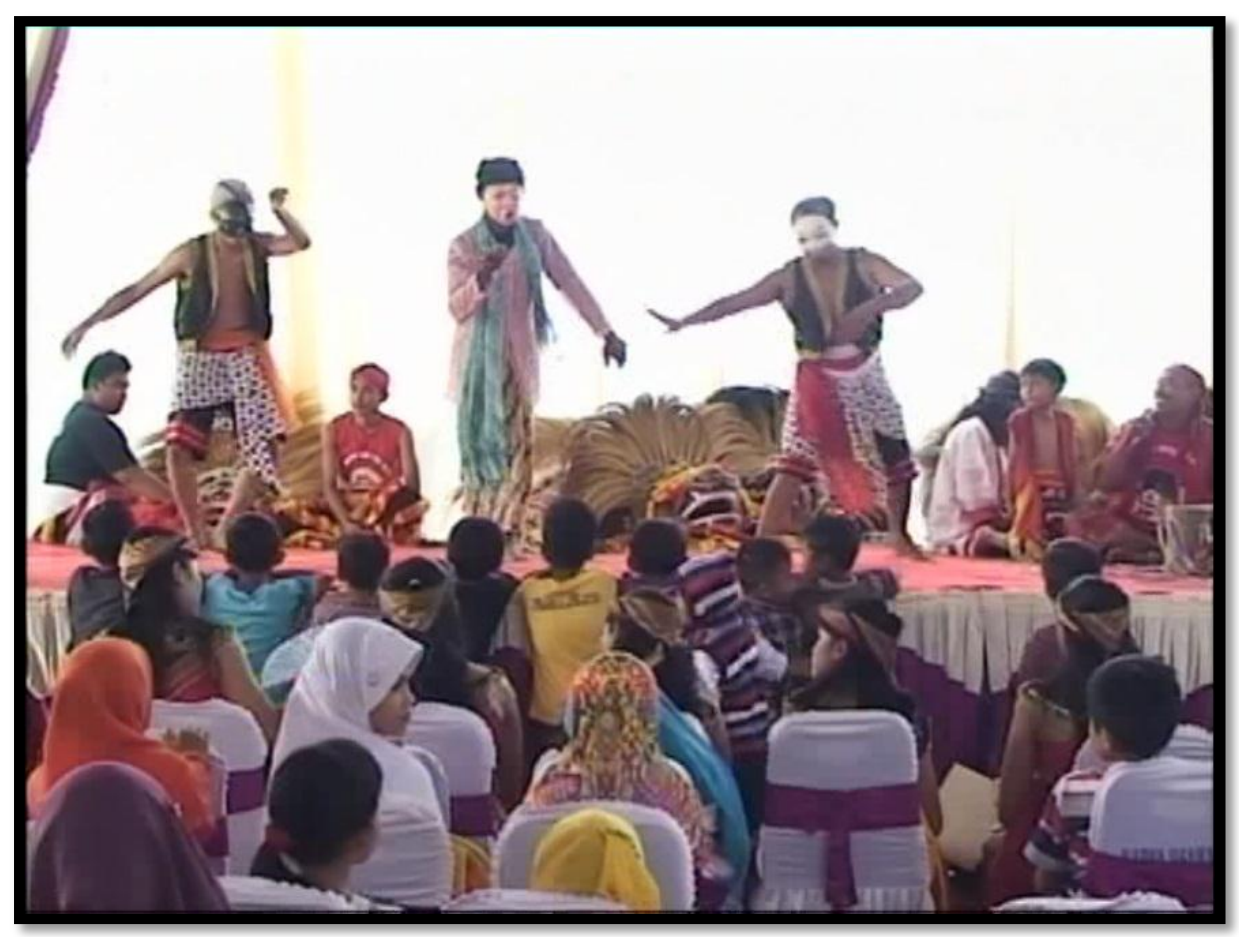

Gambar 4.15 Nggainah, Untub, dan Nayantaka

(Dok. Reni, April 2015)

Untuk menyambut kedatangannya, sinden menyanyikan lancaran gainah sebagai berikut:

Umpak:

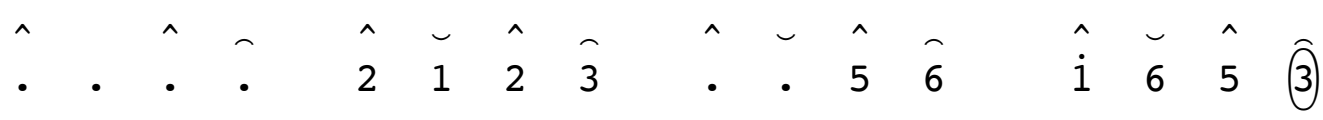

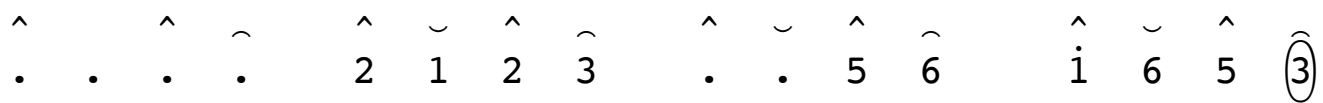




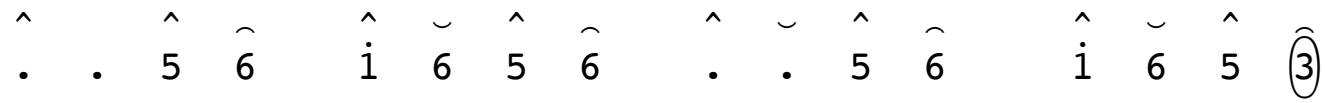

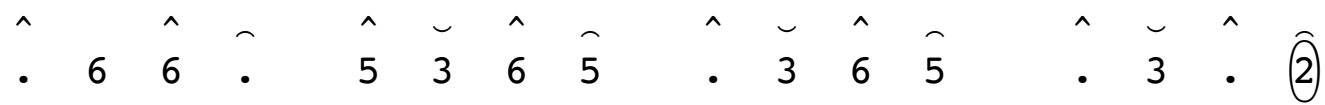

Lagu:

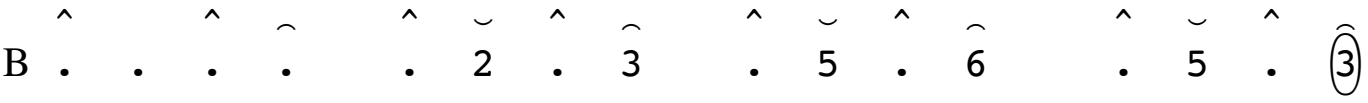

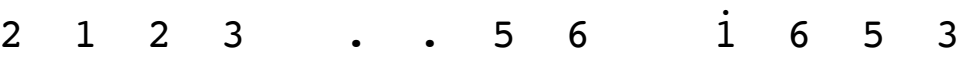

$$
\begin{aligned}
& K a-c a-r i-t a \quad \text { } \quad p a-n a-\quad k a-w a n-i-r a
\end{aligned}
$$

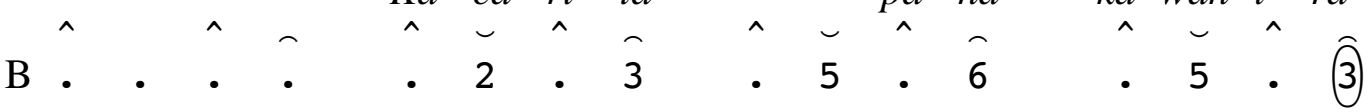

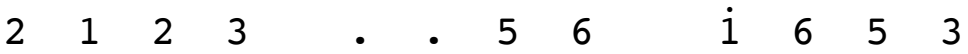

$$
\begin{aligned}
& \text { Nyi ga- } i \text { - nah un- tub na-yan-ta-ka }
\end{aligned}
$$

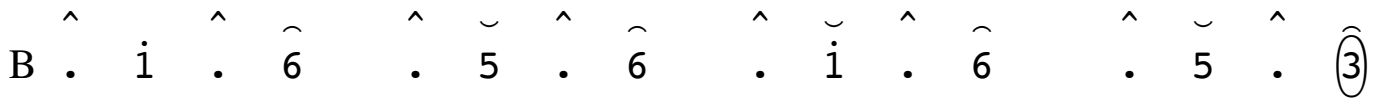

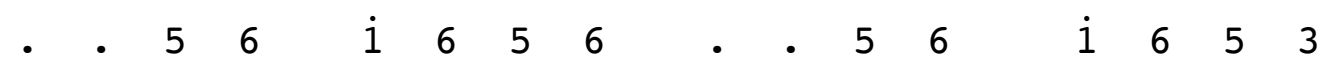

$$
\begin{aligned}
& \text { Ge-cul ku-ma-ru-cul amba-nyol am-be ba-nyol } \\
& \text { В }
\end{aligned}
$$

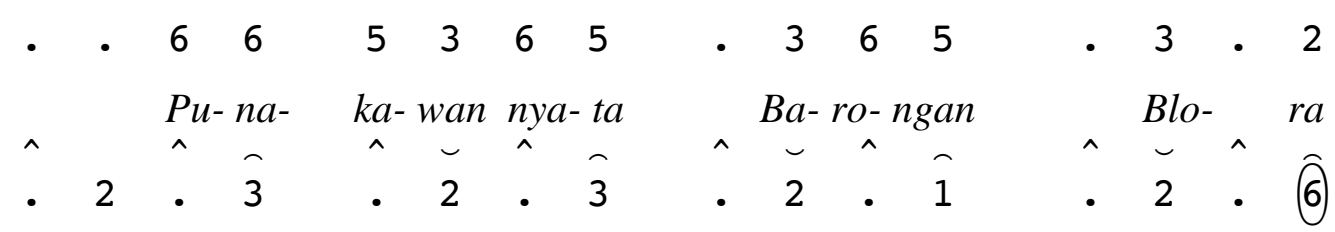

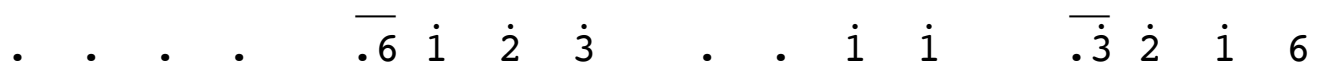

$$
\begin{aligned}
& \text { Se-ni Ba-rong nya-ta ga-we bom-bong }
\end{aligned}
$$

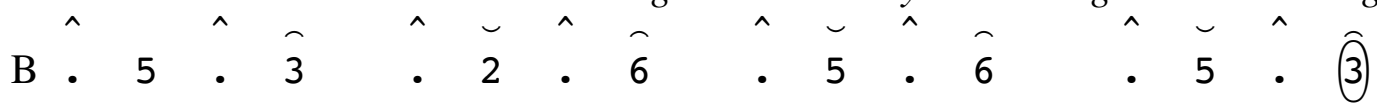

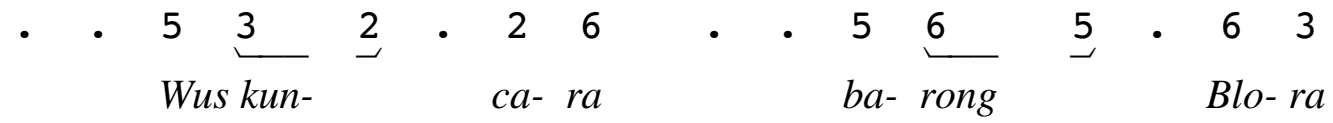




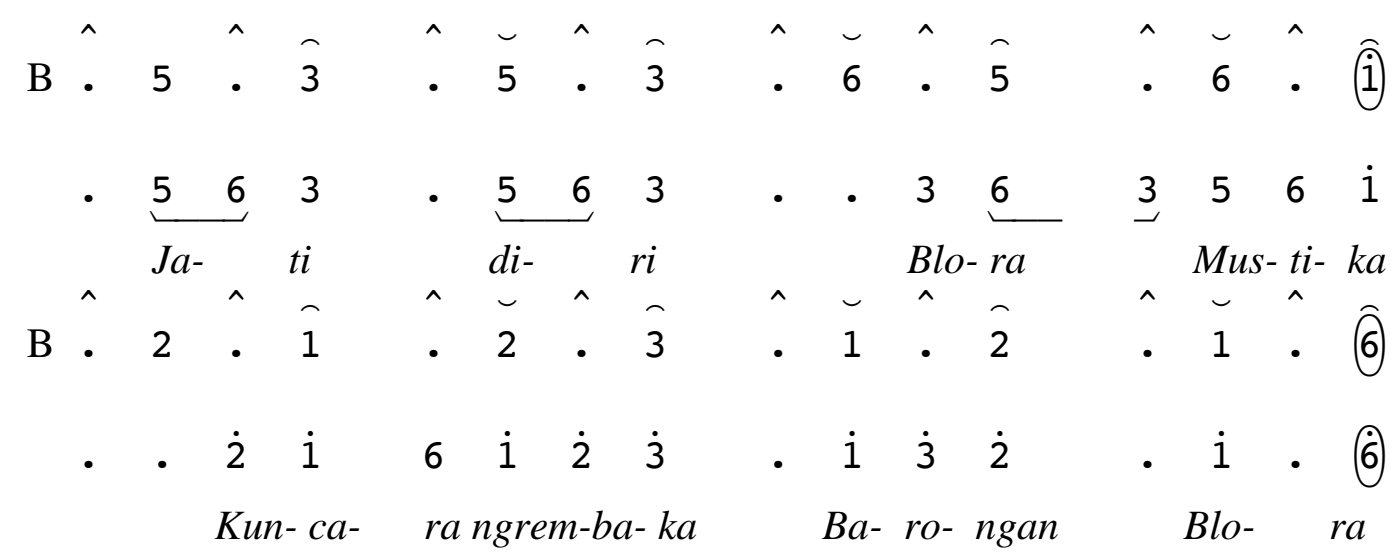

Pada bagian terakhir sebagai penutupan, ditampilkan kolaborasi tarian antara semua penari, mulai dari barongan, jaranan, nggainah, genderuwo, untub, nayantaka, tidak ketinggalan bujangganong, dan diiringi dengan musik iringan barongan menggunakan gamelan berlaras slendro dan dengan dinamika yang semakin keras semakin cepat semakin semangat hingga pada klimaksnya yang menggambarkan kondisi peperangan antara singo barong dengan para prajurit.

Berdasarkan musik pendukung yang telah dipaparkan di atas, dapat dijelaskan bahwa karawitan pendukung kesenian barongan Blora Risang Guntur Seto dengan rincian sebagai berikut:

1. Instrumen yang digunakan sebagai musik iringan dalam penyajian kesenian barongan Risang Guntur Seto adalah kendhang, kethuk, kenong, bonang, saron, demung, kempul, gong, jedor/ drum, dan terompet.

2. Musik iringan kesenian barongan Risang Guntur Seto menggunakan gamelan jawa berlaras pelog dan slendro, namun sebagian besar menggunakan laras slendro. 
3. Inti dari musik iringan kesenian barongan Risang Guntur Seto adalah musik barongan bonang mo-nem laras slendro yang dimainkan dalam tempo yang cepat dan terus menerus kecuali pada saat iringan tembang dan lagu-lagu. Ketika musik ini dimainkan, penggerong dan sinden bersahutan memberikan alok.

4. Sebagian besar gendhing nya berbentuk lancaran. Namun ada pula tembang macapat dan lagu populer anak-anak sebagai selingan.

5. Lagu-lagu yang dibawakan menceritakan tentang sejarah barongan, liriknya berisi tentang keperkasaan dari barongan itu sendiri, dan musiknya mencerminkan ciri khas Kabupaten Blora.

Sebagai informasi, pertunjukan kesenian barongan Risang Guntur Seto dalam acara ini berlangsung lama sekitar 2,5 jam. Namun terdapat pengulangan gerak di beberapa bagian, seperti penampilan singo barong yang berulang-ulang. Oleh sebab itu, peneliti meringkas inti urutan penyajian kesenian barongan Blora Risang Guntur Seto menjadi sedemikian rupa. 


\section{BAB 5}

\section{PENUTUP}

\subsection{Kesimpulan}

Berdasarkan hasil penelitian yang berjudul "Karawitan Pendukung Kesenian Barongan Risang Guntur Seto di Kabupaten Blora” dapat disimpulkan bahwa instrumen yang digunakan sebagai musik iringan dalam penyajian kesenian barongan Risang Guntur Seto adalah kendhang, kethuk, kenong, bonang, saron, demung, kempul, gong, jedor/ drum, dan terompet; musik iringan kesenian barongan Risang Guntur Seto menggunakan gamelan jawa berlaras pelog dan slendro, namun sebagian besar menggunakan laras slendro; inti dari musik iringan kesenian barongan Risang Guntur Seto adalah musik barongan bonang mo-nem laras slendro yang dimainkan dalam tempo yang cepat dan terus menerus kecuali pada saat iringan tembang dan lagu-lagu. Ketika musik ini dimainkan, penggerong dan sinden bersahutan memberikan senggakan; sebagian besar gendhing nya berbentuk lancaran, namun ada pula tembang macapat dan lagu populer anak-anak sebagai selingan; lagu-lagu yang dibawakan menceritakan tentang sejarah barongan, liriknya berisi tentang keperkasaan dari barongan itu sendiri, dan musiknya mencerminkan ciri khas Kabupaten Blora.

Keberadaan musik pendukung dalam grup kesenian barongan Blora Risang Guntur Seto sangat penting, bahkan menjadi jiwa/roh pada pertunjukan barongan, dan tidak mudah menjadi penabuh gamelan barongan. Musik pendukung dalam grup kesenian barongan Risang Guntur Seto hampir sama seperti grup barongan lainnya yang ada di Blora, karena pada dasarnya musik iringan barongan hanya 
bonang mo-nem. Tetapi, grup kesenian Risang Guntur Seto memiliki ciri khas dalam hal musik iringannya dari pola iringan, tempo maupun koleksi lagu yang beragam.

Dari segi musik iringan, grup Risang Guntur Seto memiliki ciri khas yang dapat dilihat dari gendhingnya. Cakepan yang digunakan pun banyak berisi tentang sejarah barongan Blora dan cerminan sifat-sifat barongan berupa kerakyatan, kesederhanaan, kasar, keras, kompak, dan keberanian yang dilandasi kebenaran, yang dimiliki juga oleh masyarakat Blora. Tempo yang digunakan pada musik iringan grup kesenian barongan Blora Risang Guntur Seto juga dominan cepat. Sehingga sangat dibutuhkan konsentrasi penuh dan keterampilan khusus untuk menjadi penabuh musiknya. Karena bisa dikatakan musik iringan gamelanlah yang menjadi penentu gerak barongan. Makin cepat tempo penabuh, makin energik pula gerak barongan, begitu pula sebaliknya.

\subsection{Saran}

Terkait dengan simpulan tersebut, maka saran yang dapat diberikan kepada grup kesenian barongan Risang Guntur Seto sebagai sumbangan pemikiran adalah agar lebih mengkreasikan musik iringan seperti menambah jenis bentuk gendhing yang lain sehingga koleksi lagu pun bertambah. Serta mempertahankan kekompakan antar pemain. 


\section{REFERENCES}

Arikunto, S. (1983). Prosedur Penelitian, Suatu Pendekatan Praktik. Jakarta: Bina Aksara.

Dharsono. (2007). Kritik Seni. Bandung : Rekayasa Sains.

Harsana, S. (2007). Musik Iringan Kesenian Kuntulan Desa Kasirejo Kecamatan Bodeh Kabupaten Pemalang Kajian Tentang Analisis Struktur Bentuk Musiknya. Semarang: UNNES.

Jamalus. (1988). Pembelajaran Musik Melalui Pengalaman Musik. Jakarta: Dirjen Dikti.

Ambarwangi, S., \& Suharto, S. (2014). REOG AS MEANS OF STUDENTS' APPRECIATION AND CREATION IN ARTS AND CULTURE BASED ON THE LOCAL WISDOM. Harmonia: Journal Of Arts Research And Education, $14(1)$, doi:http://dx.doi.org/10.15294/harmonia.v14i1.2789

$37-45$.

Suharto, S., \& Aesijah, S. (2014). THE LESUNG MUSIC IN THE VILLAGE OF LEDOK BLORA REGENCY. Harmonia: Journal Of Arts Research And Education, $14(1)$,

$65-71$. doi:http://dx.doi.org/10.15294/harmonia.v14i1.2851

Putra, B. (2013). PENGEMBANGAN MODEL KONSERVASI KESENIAN LOKAL SEBAGAI KEMASAN SENI WISATA DI KABUPATEN SEMARANG. Harmonia: Journal Of Arts Research And Education, 12(2). doi:http://dx.doi.org/10.15294/harmonia.v12i2.2525

Irianto, A. (2016). The Development of Jathilan Performance as an Adaptive Strategy Used by Javanese Farmers. Harmonia: Journal Of Arts Research And Education, 16(1), 38-48. doi:http://dx.doi.org/10.15294/harmonia.v16i1.5213

Hapsari, L. (2014). FUNGSI TOPENG IRENG DI KURAHAN KABUPATEN MAGELANG. Harmonia: Journal Of Arts Research And Education, 13(2). doi:http://dx.doi.org/10.15294/harmonia.v13i2.2780

Widodo, B. (2011). SLENDRO PELOG: SUATU KETERASINGAN DI DUNIA ANAK. Harmonia: Journal Of Arts Research And Education, 1(1). doi:http://dx.doi.org/10.15294/harmonia.v1i1.837

Widodo, W. (2011). Nuansa Laras Diatonik dalam Macapat Semarangan (Diatonic Scale Atmosphere in Semarang Style Macapat).. Harmonia: Journal Of Arts Research And Education, 7(1). doi:http://dx.doi.org/10.15294/harmonia.v7i1.751 
Wiyoso, J. (2011). PENGARUH DIFUSI DALAM BIDANG MUSIK TEHADAP KARAWITAN (The Influence Diffusion of Music to Karawitan). Harmonia: Journal Of Arts Research And Education, 3(2). doi:http://dx.doi.org/10.15294/harmonia.v3i2.687

Wiyoso, J. (2017). Puppet Visual Adaptation on Playing Cards as Educational Media. Harmonia: Journal Of Arts Research And Education, 16(2), 182191. doi:http://dx.doi.org/10.15294/harmonia.v16i2.5816

Budiarti, M. (2011). MENGUBAHÂ CITRA LENGGER MENJADIÂA MEDIA EKSPRESIÂA ESTETIS (To Change the Image of Lengger Into Esthetic $\hat{A}$ Medium of Expression). Harmonia: Journal Of Arts Research And Education, 4(2). doi:http://dx.doi.org/10.15294/harmonia.v4i2.708

Jazuli, M. (1994). Telaah Teoritis Seni Tari. Semarang: IKIP Press.

Joseph, W. (2001). Teori Musik 1. Semarang: UNNES.

Koentjaraningrat. (1993). Kebudayaan Jawa. Jakarta: Gramedia.

Koentjaraningrat. (2009). Pengantar Ilmu Antropologi Edsi Revisi. Jakarta: Rineka Cipta.

M.D, S. (2003). Barongan Blora. Surakarta: STSI Press Surakarta.

Martapengrawit. (1975). Catatan Pengetahuan Karawitan I. Surakarta: ASKI Surakarta.

Miller, H. M. (2001). Apresiasi Musik. Yogyakarta: Yayasan Lentera Budaya.

Moleong, L. (2007). Metodologi Penelitian Kualitatif Edisi Revisi. Bandung: PT. Remaja Rodaskarya.

Novitasari, D. K. (2013). Skripsi: Bentuk Musik Iringan Kesenian Dayakan di Kota Magelang. Semarang: Unnes.

Pawito. (2007). Penelitian Komunikasi Kualitatif. Yogyakarta: PT. LKIS Pelangi Aksara.

Sinaga, S. S. (2005). Efekrifitas Metode Singing dan Ear Training untuk Meningkatkan Prestasi Belajar Vokal SMP ditinjau dari Kemampuan Musikal. Semarang: UNNES.

Sugiyono. (2005). Memahami Penelitian Kualitatif. Bandung: Alfabeta.

Sugiyono. (2006). Metode Penelitian Pendidikan. Bandung: Alfabeta.

Sumaryanto, T. (2010). Metodologi Penelitian 2. Semarang: UNNES. 
Supanggah, R. (2002). Bothekan Karawitan I. Jakarta: Masyarakat Seni Pertunjukan Indonesia.

Tasman, A. (1997). Pengembangan Tari di Indonesia. Surakarta: Akademi Seni Karawitan Indonesia.

Wardhana, A. W. (2014). Skripsi: Musik Pendukung Kesenian Jaran Debog di Dusun Suruhan Desa Keji Kecamatan Ungaran Barat Kabupaten Semarang. Semarang: Unnes.

Wijaya, D. (2012). Skripsi: Pertunjukan Musik Calung Sebagai Pengiring Kesenian Tari Lengger di Desa Karanggedang Kecamatan Sidareja Kabupaten Cilacap. Semarang: Unnes. 
Lampiran 1

\section{PEDOMAN OBSERVASI}

1. Letak lokasi penelitian

2. Kondisi lokasi dilihat dari lingkungan alam

3. Sarana dan prasarana yang dimiliki oleh grup Kesenian Barongan Risang Guntur Seto

4. Situasi dan kondisi saat pertunjukan

5. Instrumen apa saja yang digunakan

6. Jenis gendhing dan lagu-lagu yang dimainkan pada saat pementasan

7. Urutan penyajian grup Kesenian Barongan Risang Guntur Seto 
Lampiran 2

\section{PEDOMAN WAWANCARA}

\section{Tujuan Wawancara}

Wawancara dalam penelitian ini dimaksudkan untuk mengetahui karawitan pendukung kesenian barongan Risang Guntur Seto di Kabupaten Blora.

\section{Pembatasan Masalah}

Dalam pelaksanaan wawancara ini, peneliti hanya membatasi masalah pada:

2.1 Musik iringan/ karawitan pendukung Kesenian Barongan

2.2 Bentuk lagu-lagu yang dibawakan untuk mengiringi Kesenian Barongan

2.3 Fungsi musik pengiring Kesenian Barongan

\section{Pembatasan Narasumber}

Dalam penelitian ini, peneliti hanya melakukan wawancara pada beberapa narasumber, yaitu:

3.1 Pimpinan grup kesenian barongan Risang Guntur Seto

3.2 Penabuh grup kesenian barongan Risang Guntur Seto

3.3 Masyarakat sekitar yang pernah menonton pertunjukan Kesenian Barongan atau yang pernah menanggap Kesenian Barongan

\section{Daftar Pertanyaan}

4.1 Daftar pertanyaan untuk pimpinan grup kesenian barongan Risang Guntur Seto:

1) Nama, usia, pekerjaan? 
2) Apakah nama grup Kesenian Barongan ini?

3) Mengapa Anda memberikan nama itu?

4) Bagaimanakah riwayat berdirinya grup Kesenian Barongan ini?

5) Berapakah jumlah personil dalam grup Kesenian Barongan ini?

6) Setiap berapa sekali grup ini melakukan latihan rutin?

7) Dalam acara apa sajakah grup Kesenian Barongan ini dipentaskan?

8) Alat musik apa saja yang dipakai dalam musik pengiringnya?

9) Lagu-lagu apa yang biasa dibawakan?

10) Apa ciri dari musik pengiring grup Kesenian Barongan ini?

11) Apa fungsi musik pengiring dalam Kesenian Barongan menurut Anda? Seberapa penting?

\subsection{Daftar pertanyaan untuk penabuh grup kesenian Risang Guntur Seto:}

1) Nama, usia, pekerjaan?

2) Berapa lama bergabung di grup Risang Guntur Seto?

3) Apa yang menjadi motivasi Anda untuk bergabung di grup Risang Guntur Seto?

4) Apa instrumen yang Anda mainkan?

5) Kendala apa yang biasa dialami pada saat latihan?

\subsection{Daftar pertanyaan untuk masyarakat sekitar yang pernah menanggap} Kesenian Barongan:

1) Nama, usia, pekerjaan?

2) Mengapa Anda memilih untuk menanggap Kesenian Barongan Blora? 
3) Untuk keperluan apa Anda menanggap Kesenian Barongan Blora?

4) Bagaimana menurut Anda pertunjukan Kesenian Barongan Blora?

5) Apa yang Anda sukai dari pertunjukan Kesenian Barongan Blora?

6) Bagaimana perasaan Anda setelah menyaksikan pertunjukan Kesenian Barongan Blora? 
Lampiran 3

\section{PEDOMAN DOKUMENTASI}

Dalam pengumpulan data, peneliti mendokumentasi:

1) Foto wawancara peneliti dengan narasumber

2) Foto alat/ instrumen musik yang dipakai

3) Foto pada saat pertunjukan Kesenian Barongan

4) Foto masyarakat pada saat menyaksikan pertunjukan Kesenian Barongan 
Lampiran 4

\section{TRANSKRIP WAWANCARA}

\section{KETUA GRUP RISANG GUNTUR SETO}

\section{Wawancara dengan Pak Didik selaku Ketua Grup Kesenian Barongan} Risang Guntur Seto (tanggal 19 Mei 2015)

P (Peneliti) : "Siapa nama Bapak?"

N (Narasumber) : : "Adi Wibowo atau biasa dipanggil Pak Didik."

P : "Usia berapa Pak Didik sekarang?"

N : "Saya kelahiran tahun 1971, berarti sekarang ya 34 tahun."

P : "Pekerjaan Pak Didik?"

N : "Swasta."

P : "Pak, mengapa Pak Didik memberi nama grup ini dengan Risang Guntur Seto?"

N : "Nah pertanyaan yang bagus ini. Risang Guntur Seto itu artinya kalau kami mengartikan, orang mungkin melihat Risang itu Pangeran, Guntur Seto itu bledhek putih (petir putih), oke boleh. Tapi bagi saya yang memperoleh nama itu artinya Risang oke, Guntur pemikiran saya begini kalau kita melihat petir atau guntur, orang pasti kan melihat kilatnya pasti langsung 'wah', putih itu bersih, artinya kilat itu kumoro. Jadi filosofinya Guntur Seto itu niat kumoro yang resik. Kalau Anda tanya lagi darimana saya mendapatkan nama ini, lha ini, saya nggak percaya ghaib, bukan nggak percaya. Barongan ini saya bikin manajemen yang benar. Tetapi mungkin salah satu bentuk ghaib di Guntur 
Seto, saya ketika mendirikan grup ini 20 Mei 1999, itu tau-tau saya ketika mandi ada nama Risang Guntur Seto. Ini serius. Saya konsul sama orang yang paham tentang ilmu tua, itu belum jadi barongan saya, terus kebetulan ketika jadi 20 Mei 1999 itu saya nggak tahu, bulannya Suro, mohon maaf saya kan non muslim jadi kurang paham, tau-tau ini jadi pas bulan Suro 'yowis nek ngono sesuk dimainna' itu malam Jumat Legi. Saya ingat betul nama itu saya dapat ketika saya mandi 2 hari sebelum barongan tak gebyakke. Jadi Risang Guntur Seto itu nama yang ada di fikiran langsung. Terus ini yang nggak diketahui orang, sesanti atau semboyan kami Nglanglanging Sukmo Pinjunjul, kata-kata itu muncul juga ketika saya bangun tidur. Pehamaman saya pribadi, nglanglanging itu kan pengembaraan atau melalang buana, sukmo itu niat, pinunjul itu bersih. Jadi pencarian atau pengembaraan niat yang suci, yang saya ajarkan ke anak buah saya bahwa pemahaman saya nglanglanging sukmo pinunjul itu pencarian niat yang bersih, belajar. Jadi di Guntur Seto itu nggak ada kata nggak belajar, selalu belajar dan tidak pernah puas diri."

P : "Bagaimana riwayat berdirinya grup ini? Berarti tanggal 20 Mei 1999 ya, Pak?"

N : "Iya, betul."

P : "Lalu berapa jumlah personil dalam grup ini?"

$\mathrm{N}$ : "Kalau diitung dengan angka, anggota tetapnya ada 32. Tetapi kalau diminta seperti acara pawai, karnaval, ya sesuai kebutuhan itu bisa lebih bisa sampai 40-60, tergantung konsep karya yang digarap. Festival barong kemarin kita sampai 80, 100 pun siap. Artinya, disini ada regenerasi dan hebatnya anak-anak 
menurut saya itu ora sak wayah-wayah tak jak pun mau. Karena disini juga berlaku persaingan. Misalnya kudanya itu ada 25 anak, tetapi kan yang saya pakai hanya 8-12, kadang-kadang di rolling kadang-kadang ya mereka bersaing."

P : "Setiap berapa hari sekali grup ini melakukan latihan rutin?"

$\mathrm{N}$ : “Kalau latihan yang pasti itu sebelum pentas. Tetapi kalau yang rutin, jujur sekarang ini kami jarang latihan karena kepentok jadwal temen-temen, jadi 2 minggu sekali.”

P : "Dalam acara apa sajakah grup Risang Guntur Seto biasanya tampil?"

$\mathrm{N}$ : "Ya biasanya di acara orang punya kerja, nikahan, khitanan, terus event-event penyambutan tamu, hari jadi kabupaten, mewakili festival-festival, dll.”

P : "Alat apa saja yang digunakan sebagai musik pengiring kesenian barongan?"

$\mathrm{N}$ : "Yang utama di barongan itu kan kendhang, bonang dengan laras mo-nem. Nah ini yang membedakan dengan barongan manapun. mo-nem bonang slendro, kedhuk, kempul nem, lalu di kami ditambah lagi ada gong suwuk, saron, demung, jedor/drum, dan terompet. Jadi karena perkembangan untuk mengiringi gendhing-gendhing atau tarian jaranannya itu saron, demung agar tidak menjenuhkan. Tetapi rohnya barongan ya caranya orang Blora 'tholekthogling tholekthogling' nah mo-nem mo-nem mo-nem, slendro. Kalau barongan ponorogo kan nem-mo pelog. Barongan lain beda lagi 'thong thek thong thong gling thong'. Kan sebenernya yang menjadikan Barongan Spirit of Life dari orang Blora itu sebenarnya ya 'tholekthogling tholekthogling' dinamis, keras, energik, itulah yang menggambarkan ekspresi orang Blora.” 
P : "Lagu apa saja yang biasa dibawakan pada saat pementasan?"

$\mathrm{N}$ : "Kalau gendhing disesuaikan dengan permainan. Jadi kalau penthulan ya gendhingnya penthulan kami punya sendiri, jaranan juga ada sendiri gendhingnya. Kecuali pada saat selingan, nah itu ada gendhing-gendhing yang sekarang-sekarang misalnya Caping Gunung, dll. Tapi yang pakem ya Genderuwo Momong itu ketika barongan berjalan di tengah."

P : "Lalu apa ciri khas dari musik pengiring Grup Kesenian Risang Guntur Seto yang menjadi pembeda dengan grup kesenian yang lain?”

N : "Ritme. Kecepatan. Nah ini. Sak mBlora itu harusnya sama, mo-nem mo-nem mo-nem. Tetapi ada yang lebih spesifik grup kami yaitu tempo. Jadi pengendhang tau, ini kok barongannya semakin kendho, jadi ditambah lagi iringannya makin cepat makin semangat, dan itu biasanya tidak bisa di grup lain. Karena makin cepat tempo penabuh, barongannya semakin keras dalam arti geraknya semakin energik. Pemainpun harus pintar berfikir gerakan mana yang membuang energi percuma dan mana yang tidak. Jadi kalau tidak terbiasa ya bisa ngos-ngosan."

P : "Menurut Pak Didik, seberapa penting fungsi musik pengiring dalam kesenian barongan?"

$\mathrm{N}$ : "O sangat penting. Justru rohnya ya di gamelan itu, musik pengiringnya. Yang membuat barongan ameh niba tangi ameh jungkir walik ya musik pengiringnya. Dan tidak gampang lho jadi pengiring musik barongan itu.”

P : "Baik Pak, terima kasih." 
Lampiran 5

\section{TRANSKRIP WAWANCARA \\ PENGRAWIT GRUP RISANG GUNTUR SETO}

\section{Wawancara dengan Mas Ugi selaku pengrawit grup kesenian Risang Guntur} Seto tanggal (6 Juni 2015)

P (Peneliti) : "Maaf sebelumnya siapa nama Bapak?"

N (Narasumber) : "Nama saya mas Sugiarto, panggilan akrab mas Ugi."

P : "Pekerjaan Bapak?"

N : "Swasta."

P : "Usia?"

N : "Usia sekitar 43."

P : "Sudah berapa lama Bapak bergabung di grup kesenian Risang Guntur Seto?"

N : "Risang Guntur Seto termasuk saya sudah dari awal, mbak. Jadi memang dulu itu ceritanya sama mas Adi Wibowo selaku ketua, saya kan termasuk orang yang mendirikan Risang Guntur Seto disitu. Kalau dari Risang Guntur Seto lho ya. Kalau dulu kan awalnya barongan itu dari barongan desa, setelah desa ini merasa istilahnya kurang berkembang kita berusaha sama mas Didik bagaimana caranya kita itu orang Blora punya kesenian Blora kita bisa mengembangkan kesenian barongan itu bisa dikenal di masyarakat umum. Akhirnya terus kita sama mas Didik bercita-cita, waktu itu saya di Ponorogo, pie carane barongan iki iso koyok reog Ponorogo. Jadi dari awal tahun 1999, saya dibantu temen-temen yang dulu anggota belum seperti ini. Anggota 
sebagian masih orang-orang kita sendiri terus akhirnya kita itu bisa merekrut mereka-mereka itu dengan bertahap gitu. Akhirnya ya bisa terkumpul menjadi grup seperti yang kita kenal saat ini."

P : "Berarti dari awal ya Bapak bergabung?"

$\mathrm{N}$ : "Dari awal saya. Termasuk anak saya juga dulu dari kecil dari nol sampai sekarang dia ikut jadi pengrawitnya Guntur Seto."

P : "Lalu motivasi Bapak untuk bergabung di grup Risang Guntur Seto itu apa? Apakah hanya sekedar hobi atau dijadikan sebagai profesi?"

$\mathrm{N}$ : "Begini mbak. Namanya orang seni itu tidak bisa nuwun sewu ya, dikatakan seni ya seni dikatakan tidak ya tidak. Tapi dari kecil saya itu ibaratnya sudah mendarah daging dengan barongan. Dimana dengar suara tholekthoging tholekthoging kita pasti cari. Jadi kita bukan untuk suatu kita harus ngikut ada grup atau apa kita harus nyoh iki gajimu sakmene tidak seperti itu. Jadi kalau mas iki ana dana sakmene mas turahane dinggo kas karek sakmene ya kita tampung kita terima nggak papa. Ibaratnya teman kita satu grup itu ada yang punya kerja mas diaturi main teng mrika dengan apa adanya kita dikasih makan dikasih napa cukup, ya nggak masalah. Itu hanya untuk suatu kekompakan supaya terjalin grup ini bisa dalam akses yang tetap dan nggak pecah. Kalau bisa kan ini akhirnya inti-inti dari grup Risang Guntur Seto ini kan masih bisa berkembang. Kalau yang lain ini kita bisa merekrut mereka untuk mendidik mereka supaya dia itu kalau dulu namanya wong ngerti barongan iku kesane kok koyok kesenian yang terlalu arrogant kan, kalau sekarang ya kita kemas kayak gitu. Jadi kalau saya, jadi penabuh di grup 
Risang Guntur Seto kalau hobi ya tetep hobi, kalau profesi ya kalau kita hanya mengandalkan barongan aja kan ya tidak bisa tercukupi, kita sama cari pekerjaan yang lain. Contohnya yang ada aja, jadi tidak hanya pegawai swasta, pemain Risang Guntur Seto PNS pun juga ada. Jadi itu hanya suatu jiwa yang sudah melekat dengan barongan."

P : "Lalu Bapak sendiri di grup kesenian Risang Guntur Seto memegang alat musik apa?"

N : "Saya bonang."

P : “Apakah setiap pemusik itu bisa memainkan alat musik yang lain?”

$\mathrm{N}$ : "Jadi maaf ya mbak, kita ini bukan dari grup yang benar-benar sudah terlatih dalam arti kata tau daripada nada dan sebagainya, tetapi kan kalau barongan sifatnya hanya itu-itu aja, bonang kendhang. Tetapi disini kalau saya pegang bonang khusus bonang ya saya bonang. Saya nggak bisa pegang yang lain kecuali kethuk dan kempul. Tetapi kalau paten, kendhang, itu harus satu orang, karena pemahamannya kendhang itu kan artinya yang bisa ngangkat bisa menghentikan bisa menetralisir semuanya itu kendhang. Nafas daripada gamelan barongan itu ada di kendhang. Walaupun penunjang utamanya tholekthogling tholekthogling itu juga gitu mbak, salah kita mukul satu kali aja, lainnya bubar. Itu pasti. Karena dulu alat musik yang ada itu kan hanya kendhang, bonang, kempul. Gitu aja. Tetapi dengan pembaharuan saat ini untuk merespon pemain supaya seneng kita kasih bedhug, saron demung, drum, nah seperti itu." 
P : "Berarti alat musik yang membutuhkan keahlian tertentu itu kendhang ya, Pak?"

$\mathrm{N}$ : "Iya. Kalau kendhang kan memang nafasnya gamelan kan disitu, baik wayang, tayub, atau barongan. Dan itu sangat sulit dan butuh ketekunan untuk mencermati daripada iringan sendiri. Jadi kalau iringan tayub seperti ini, iringan wayang seperti ini, iringan barongan juga seperti ini."

P : “Apakah jumlah penabuh lebih banyak daripada jumlah alat musiknya? Jadi seumpama ada yang tidak bisa hadir ada yang menggantikan, atau gimana?"

$\mathrm{N}$ : "Mayoritas paling tidak kita itu punya cadangan. Namanya orang kan itu ya pasti punya kebutuhan atau keperluan mendadak, kita butuh. Kalau di Risang Guntur Seto kan sudah ada. Seperti saya, penabuh bonang, anak saya pun di belakang saya akan mengikuti, bagaimana caranya. Misal saja saya tidak bisa hadir, anak saya bisa menggantikan. Kalau anak saya kan dia kendhang bisa, bonang juga bisa, kempul bisa, bedhug apalagi. Dia kan pembedhugnya pak dalang Sigid. Jadi saya juga bangga ini, tidak hanya alat musik yang ada di barongan dia bisa, tapi wayang pun dia juga ikut tampil."

P : "Dengan adanya kreasi iringan musik dari barongan Risang Guntur Seto yang baru, apakah semua pemain itu bisa mengikuti? Apa kendalanya?"

$\mathrm{N}$ : "Semua itu harus dituntut untuk bisa mengikuti. Karena kalau penabuh itu kan mengikuti penari. Kalau selama penari ini tidak bisa memahami daripada iringan, ya njenengan pirsa sendiri, ada yang sedang ngangkat kaki tiba tiba dher!! ada yang lagi goyang kiri dher!! belum pas. Jadinya kita harus tetap menyesuaikan, iringan segini penari harus ngikuti segini. Kalau memang 
penari ini merasa keberatan, tolong istilahnya temponya diturunkan sedikit. Kalau ukuran segini kita juga harus menyesuaikan enak apa nggak ya didengar. Kalau didengar nggak enak, kenapa kita yang menabuh tidak bisa menyelaraskan. Jadi akhirnya kita ya memang harus menyesuaikan sendiri antara penari dan penabuh, dan itu juga butuh waktu lama paling tidak $3 \mathrm{x}$ latihan. Itupun kadang ada yang bisa ada yang tidak." P : "Baik pak, terima kasih." 
Lampiran 6

\section{TRANSKRIP WAWANCARA \\ PENANGGAP GRUP RISANG GUNTUR SETO}

\section{Wawancara dengan Pak Sigid selaku penanggap kesenian barongan Risang \\ Guntur Seto dalam acara khitanan putranya, sekaligus penata musik tanggal} (10 Mei 2015)

P (Peneliti) : "Baik sebelumnya siapa nama Bapak?”

N (Narasumber) : : "Sigit Ariyanto"

P : "Usia?"

N : "36 nek ora kleru."

P : "Pekerjaan?"

N : "Dalang."

P : "Mengapa Bapak memilih untuk menanggap kesenian barongan Blora Risang Guntur Seto?

$\mathrm{N}$ : "Secara umum saya dan anak saya senang dengan barongan, lebih-lebih Risang Guntur Seto karena ada kedekatan teman antara saya dengan Mas Didik sejak dulu. Secara khusus karena dulu saya nadzar 'kalau anak saya khitan tak tanggapke Risang Guntur Seto. Jadi pas wingi tak tanggapke tenan.”

P : "Jadi keperluan menanggap ini pas kemarin acara khitan ya, Pak?"

N : "Iya khitanan anak saya, Awang."

$\mathrm{P}$ : "Bagaimana menurut Bapak pertunjukan kesenian barongan Risang Guntur Seto?" 
N : "Menurut pengamatan saya, Risang Guntur Seto itu memiliki nilai plus dibanding grup kesenian barongan yang lain. Bahkan Risang Guntur Seto menjadi trend center garapan apa saja baik musik maupun tariannya. Karena Risang Guntur Seto juga barongane ora sak-sak e, ora awur-awuran, sudah ditata mulai dari koreografi dan iringannya."

P : "Berarti ada perbedaan iringan ya dari Risang Guntur Seto dengan yang lain?"

N : "Sangat berbeda. Karena Risang Guntur Seto itu didukung skill yang mampu, bukan seniman awur-awuran, bahkan grup saya Cakraningrat pun sebagian ada yang ikut Risang Guntur Seto. Jadi untuk latihan garapan yang agak sulit pun sebentar saja sudah bisa, sudah terbiasa."

P : “Apa yang Bapak sukai dari pertunjukan kesenian barongan Risang Guntur Seto?"

$\mathrm{N}$ : "Yang saya sukai? Nggak ada yang khusus ya, secara global saya suka barongan. Terutama barongan itu kan ada perbandingannya dengan reog, barongan dan reog kalau dipelajari dari segi musiknya itu lebih rancak dan lebih dinamis barongan."

P : "Bagaimana perasaan Bapak setelah menyaksikan pertunjukan Risang Guntur Seto?"

$\mathrm{N}$ : “Seneng, seneng banget kemarin pas menyaksikan grupnya Mas Didik, puas lah puas banget. Pertunjukannya kemarin bagus. Kan biasanya barongan pertunjukannya lesehan, panggunge sak-sak $e$, nah kemarin saya buatkan 
panggung khusus dan depannya saya beri kursi jadi seolah-olah seperti nonton konser."

P : "Pak Sigid cerita dong mengenai musiknya barongan Risang Guntur Seto."

N : "Musiknya? Oke. Musik barongan iku kan mung bonang, kempul, kendhang. Mo-nem mo-nem mo-nem, karo kendhang thok, belum ada balungan, kempul e nem, suwukan loro, terus gong gedhi nem perkembangannya, pakai terompet, sok pakek jeglug. Sejarahnya kan dinamisnya mo-nem mo-nem mo-nem dulu kan memang untuk trans pemanggil roh agar masuk, konsentrasi untuk mengundang roh dimensi lain. Jadi ketika fokus mo-nem mo-nem mo-nem, itu memudahkan kita untuk konsentrasi. Kalau garapan saya kan itu tambahan, soalnya nek barongan kan tetep tetakndhangndhanggling .. (membunyikan suara kendhang buko) terus ana asmarandhana .. nanana, cakepan itu yang bikin saya. Terus ada nggainah, untub, nayantaka itu kan yang bikin juga saya. Terus gudhangan madyambantarangin itu kan yang buat saya. Itu polanya sudah lancaran, dan garapannya slendro semua. 
Lampiran 7

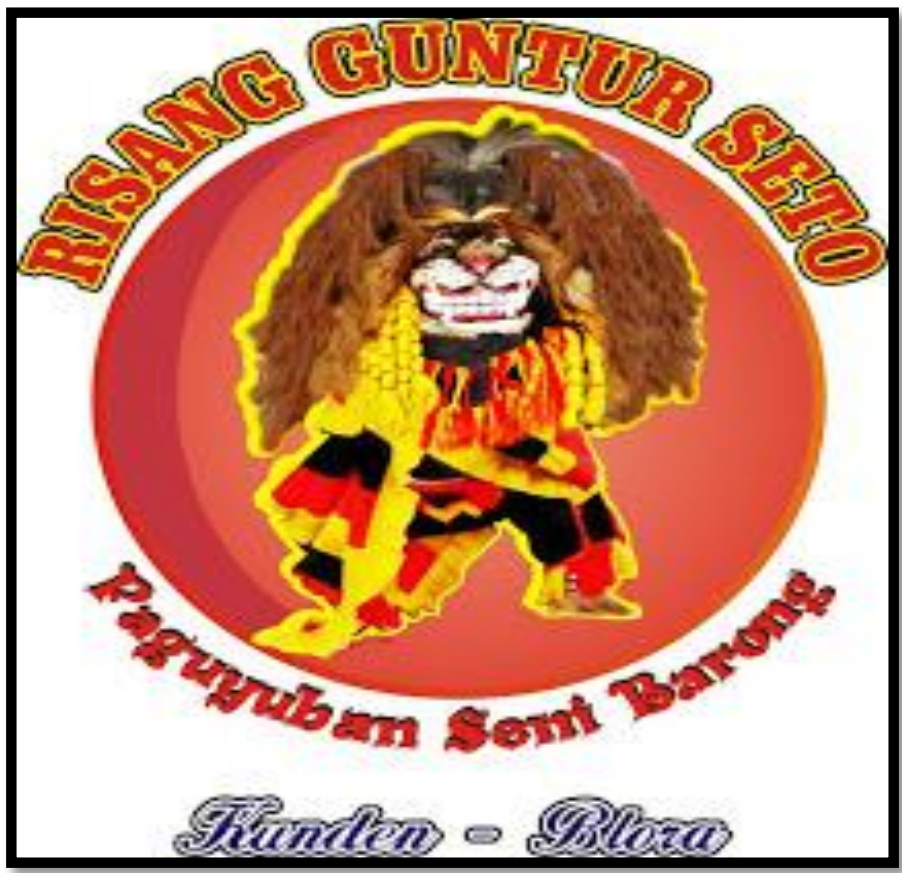

Gambar 1 Logo Grup Risang Guntur Seto

(Sumber: dok. Reni, 2015)

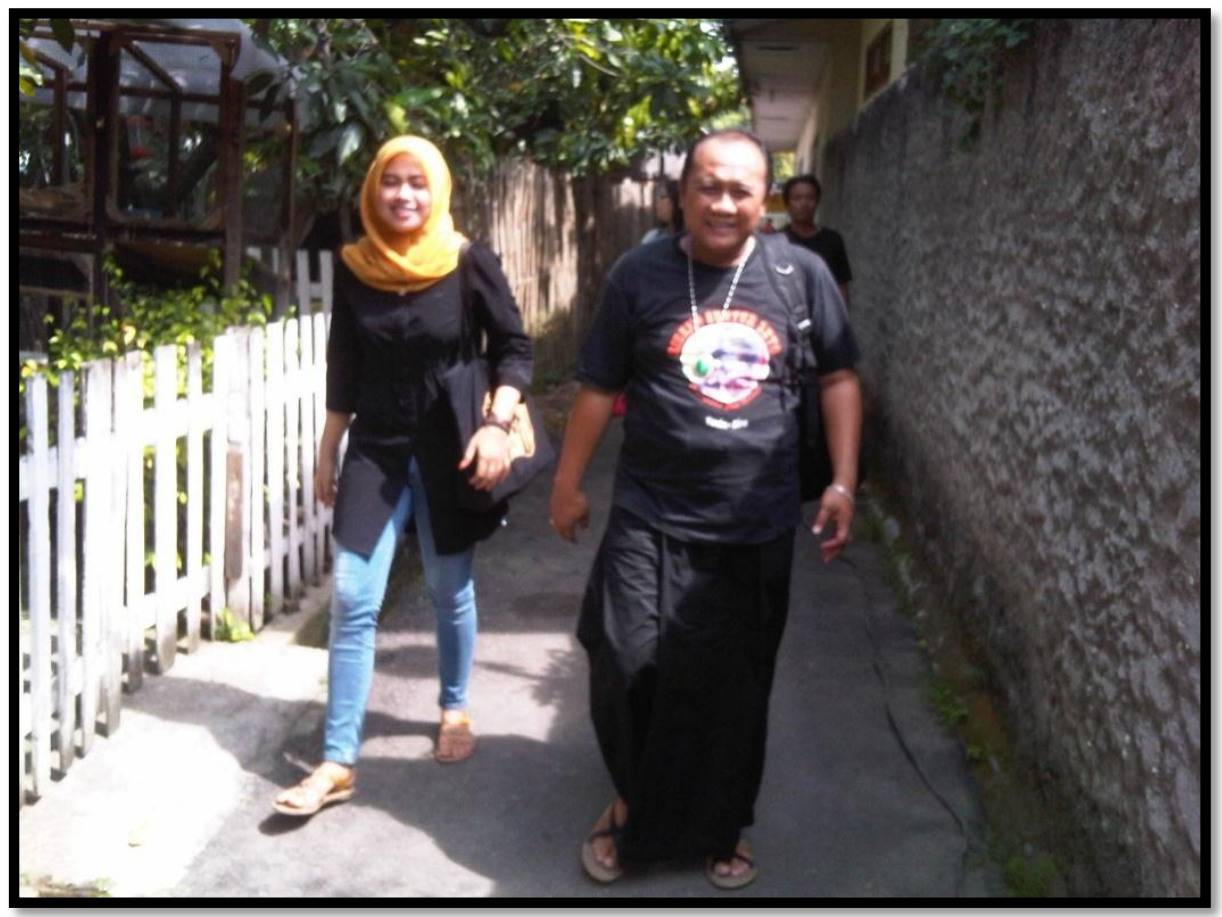

Gambar 2 Menuju lokasi pementasan (peneliti dengan ketua grup) (Sumber: Foto Reni, 2015) 


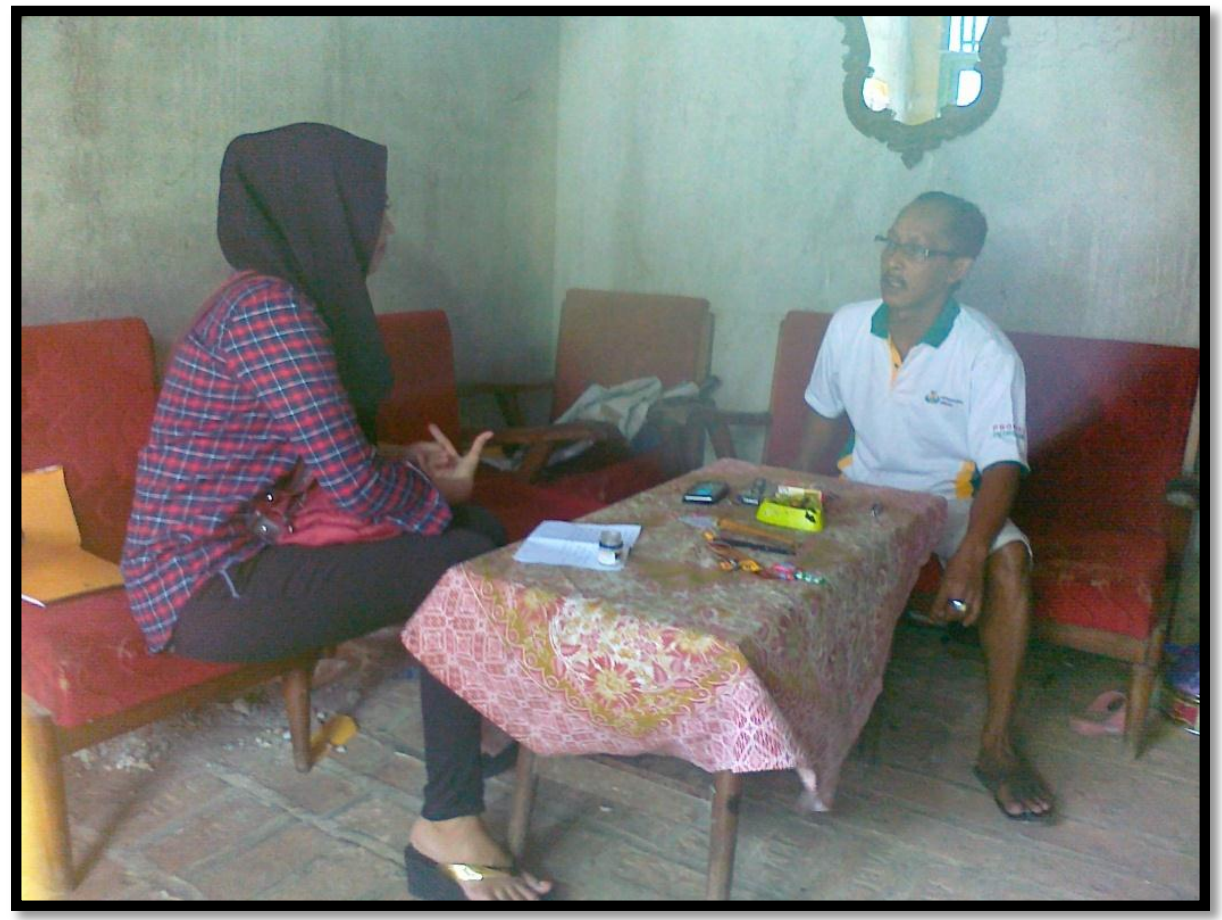

Gambar 3 Wawancara dengan Pak Ugi (penabuh barongan) (Sumber: Foto Reni, 2015)

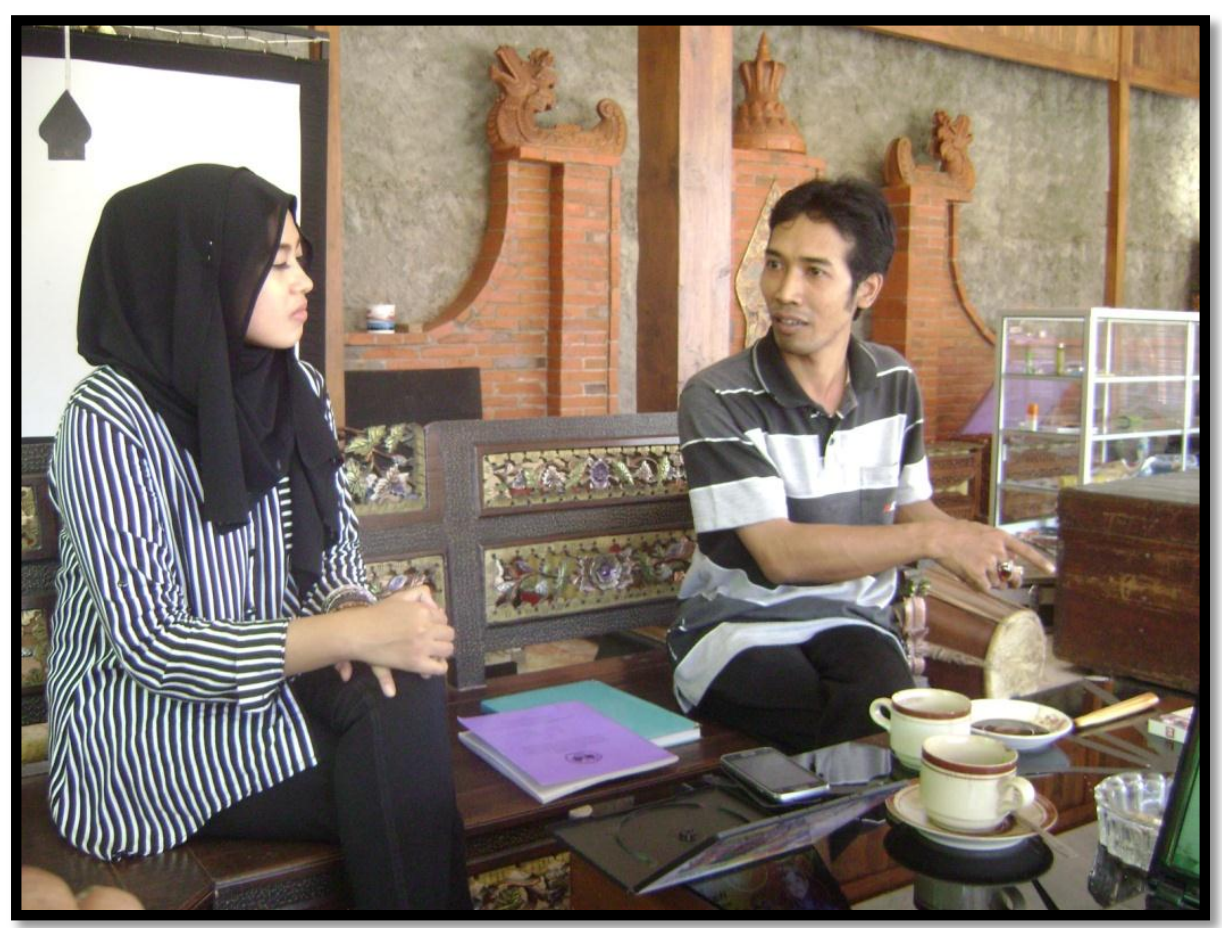

Gambar 4 Wawancara dengan Pak Sigid (penanggap barongan) (Sumber: Foto Reni, 2015) 


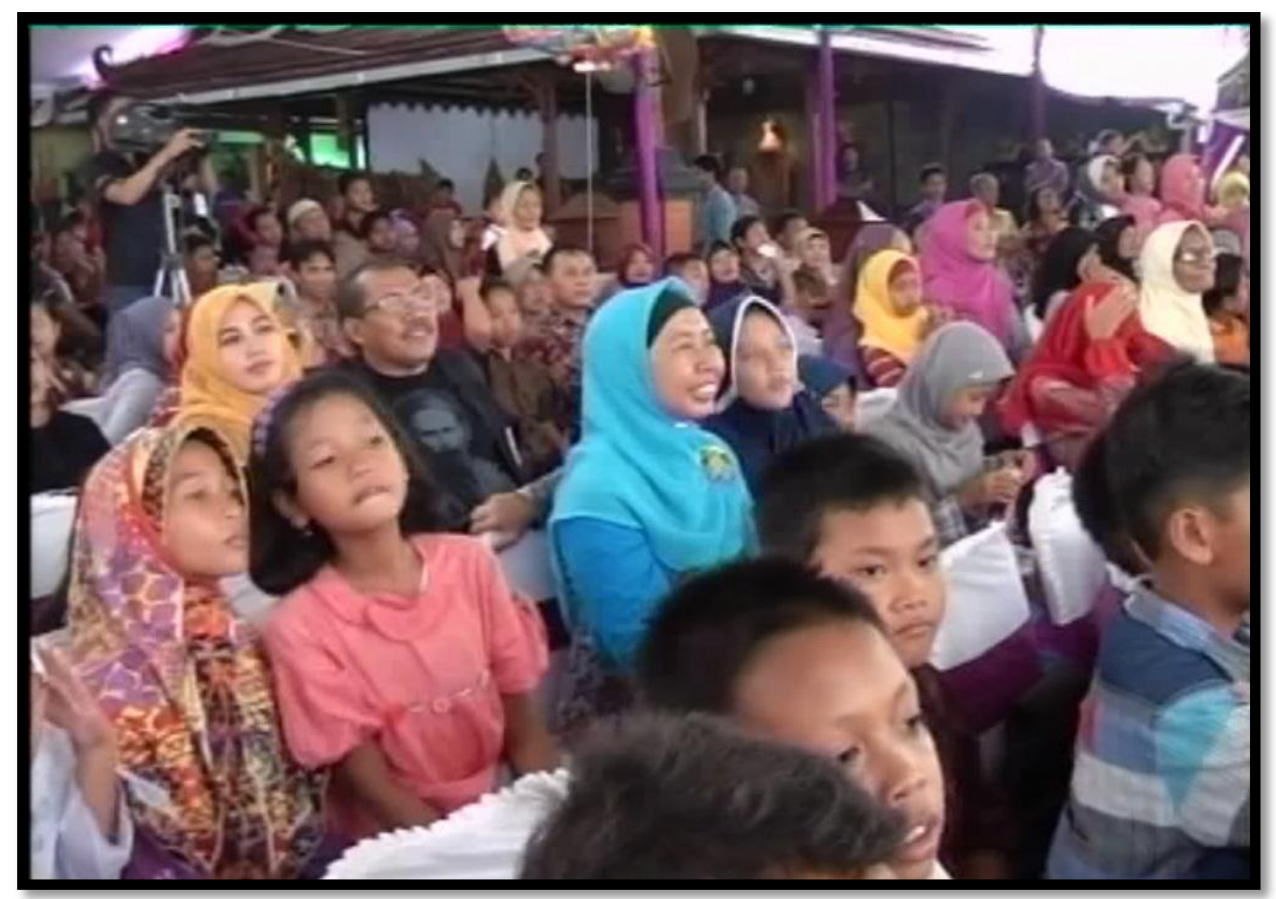

Gambar 5 Penonton pertunjukan kesenian barongan Risang Guntur Seto (Sumber: dok. Reni, 2015)

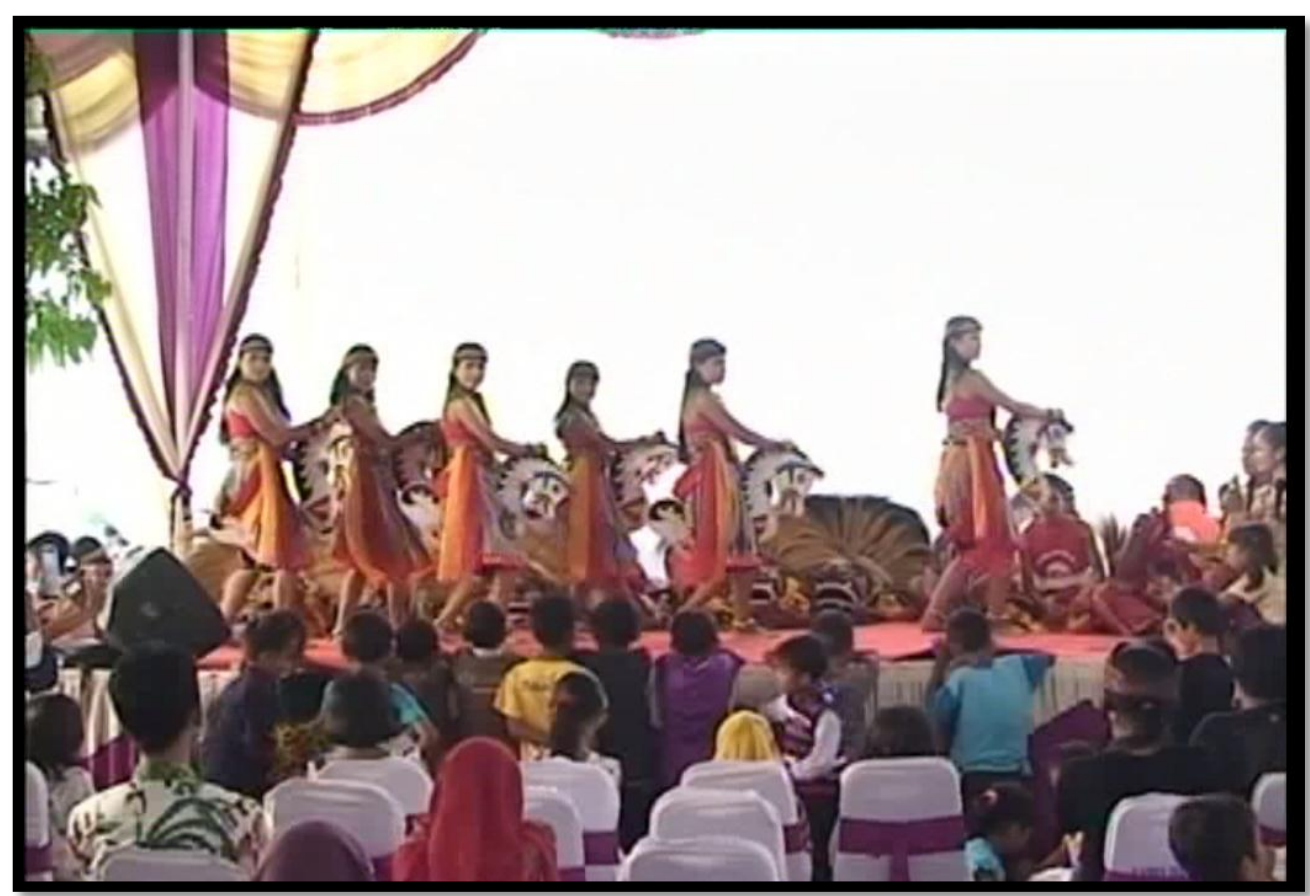

Gambar 6 Antusias penonton

(Sumber: dok. Reni, 2015) 
Lampiran 8

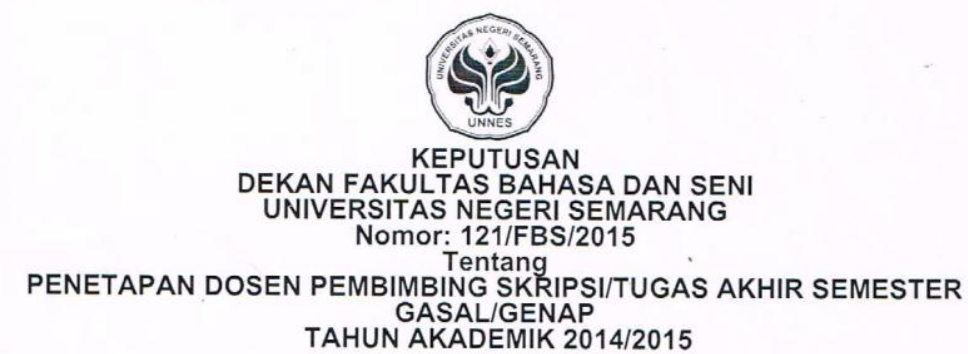

Menimbang : Bahwa untuk memperlancar mahasiswa Jurusan/Prodi Seni Drama, Tari, dan Musik/Pend Sendratasik Fakultas Bahasa dan Seni membuat Skripsi/Tugas Akhir, maka perlu menetapkan Dosen-dosen Jurusan/Prodi Seni Drama, Tari, dan Musik/Pend. Sendratasik Fakultas Bahasa dan Seni UNNES untuk menjadi pembimbing.

Mengingat : 1. Undang-undang No.20 Tahun 2003 tentang Sistem Pendidikan Nasional (Tambahan Lembaran Negara RI No.4301, penjelasan atas Lembaran Negara RI Tahun 2003 Nomor 78)

2. Peraturan Rektor No. 21 Tahun 2011 tentang Sistem Informasi Skripsi UNNES

3. SK. Rektor UNNES No. 164/O/2004 tentang Pedoman penyusunan Skripsi/Tugas Akhir Mahasiswa Strata Satu (S1) UNNES;

4. SK Rektor UNNES No.162/O/2004 tentang penyelenggaraan Pendidikan UNNES;

Menimbang : Usulan Ketua Jurusan/Prodi Seni Drama, Tari, dan Musik/Pend. Sendratasik Tanggal 8 Januari 2015

Menetapkan

\section{MEMUTUSKAN}

PERTAMA : Menunjuk dan menugaskan kepada:

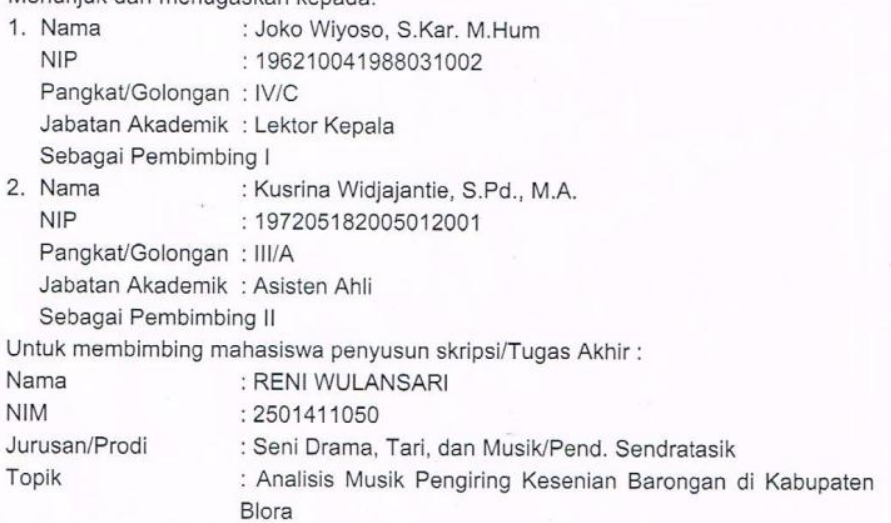

KEDUA : $\quad$ Keputusan ini mulai berlaku sejak tanggal ditetapkan.

Tembusan

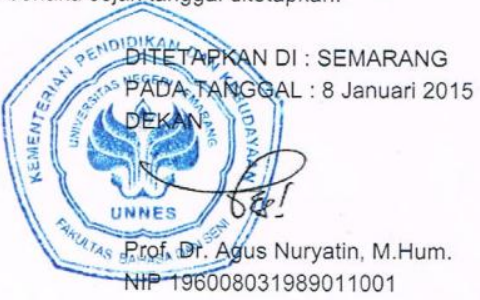

. Pembantu Dekan Bidang Akademik

2. Ketua Jurusan

3. Petinggal

|IIIIIIIIIIIIII

2501411050 


\section{Lampiran 9}

KEMENTERIAN PENDIDIKAN DAN KEBUDAYAAN
UNIVERSITAS NEGERI SEMARANG
FAKULTAS BAHASA DAN SENI
Gedung B0, Kampus Sekaran, Gunungpati, Semarang 50229
Telp./Fax (024) 8508010, Email: fbs@unnes.ac.id
Laman: http://fbs.unnes.ac.id

Nomor : 1052/UN37.1.2/LT/2015

Lamp. : :-

Hal. : Permohonan Izin Penelitian

Yth. Ketua Grup Kesenian Barongan Risang Guntur Seto

di tempat

Dengan hormat kami beritahukan bahwa dalam rangka penyusunan skripsi mahasiswa kami,

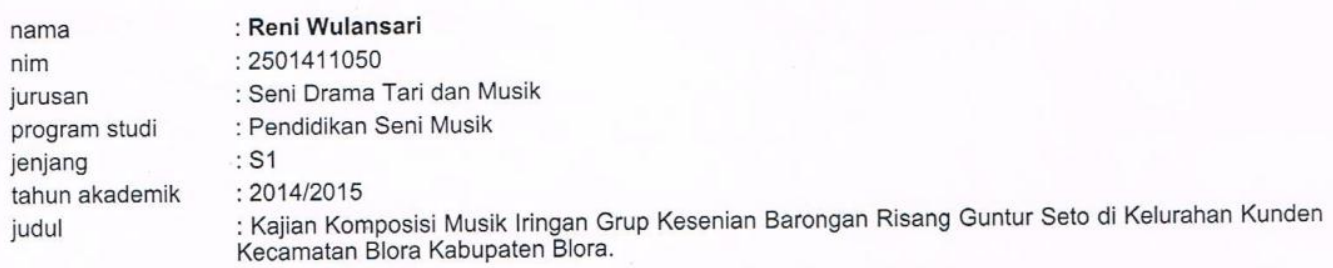

akan mengadakan penelitian di Lembaga/Instansi yang Saudara pimpin, waktu pelaksanaan Mei 2015 s.d selesai Untuk itu kami mohon Saudara berkenan memberikan izin kepada mahasiswa di atas untuk keperluan tersebut.

Atas perhatian dan kerja sama Saudara, kami sampaikan terima kasih.

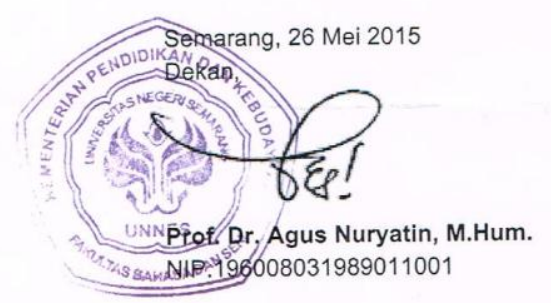

Tembusan:

1. Pembantu Dekan Bidang Akademik

2. Ketua Jurusan

3. Pertinggal 
Lampiran 10

\section{SURAT KETERANGAN PENELITIAN}

Yang memberi keterangan di bawah ini:

Nama : Grup Kesenian Barongan Blora Risang Guntur Seto

Alamat $\quad$ : J1. Gunung Wilis, Kelurahan Kunden Kecamatan Blora Kabupaten Blora

Menerangkan bahwa mahasiswa yang tertera di bawah ini:

Nama $\quad$ : Reni Wulansari

NIM : 2501411050

Jurusan/Prodi : Pendidikan Seni Musik/PSDTM

Fakultas : Bahasa dan Seni

Universitas : Universitas Negeri Semarang

Telah benar-benar melakukan penelitian tentang grup kesenian barongan Blora Risang Guntur Seto sebagai objek penelitian di tugas akhir dengan judul skripsi MUSIK PENDUKUNG GRUP KESENIAN BARONGAN RISANGGUNTUR SETO DI KELURAHAN KUNDEN KECAMATAN BLORA KABUPATEN BLORA. Kegiatan penelitian tersebut berlangsung dari bulan Mei-Juli 2015.

Demikian surat keterangan ini kami buat untuk digunakan sebagaimana mestinya.

Blora, 18 Oktober 2015

Ketua Grup Risang Guntur Seto

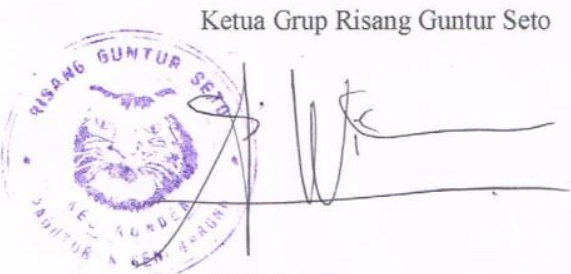

Adi Wibowo 